University of Tennessee Health Science Center

UTHSC Digital Commons

\title{
$5-2012$
}

\section{Beta-2-Adrenergic Receptor Regulates Insulin Signaling to Reduce Cell Death in Müller Cells}

Robert Jason Walker

University of Tennessee Health Science Center

Follow this and additional works at: https://dc.uthsc.edu/dissertations

Part of the Endocrine System Diseases Commons, Eye Diseases Commons, and the Medical Cell Biology Commons

\section{Recommended Citation}

Walker, Robert Jason , "Beta-2-Adrenergic Receptor Regulates Insulin Signaling to Reduce Cell Death in Müller Cells" (2012). Theses and Dissertations (ETD). Paper 284. http://dx.doi.org/10.21007/ etd.cghs.2012.0339.

This Dissertation is brought to you for free and open access by the College of Graduate Health Sciences at UTHSC Digital Commons. It has been accepted for inclusion in Theses and Dissertations (ETD) by an authorized administrator of UTHSC Digital Commons. For more information, please contact jwelch30@uthsc.edu. 


\section{Beta-2-Adrenergic Receptor Regulates Insulin Signaling to Reduce Cell Death in Müller Cells}

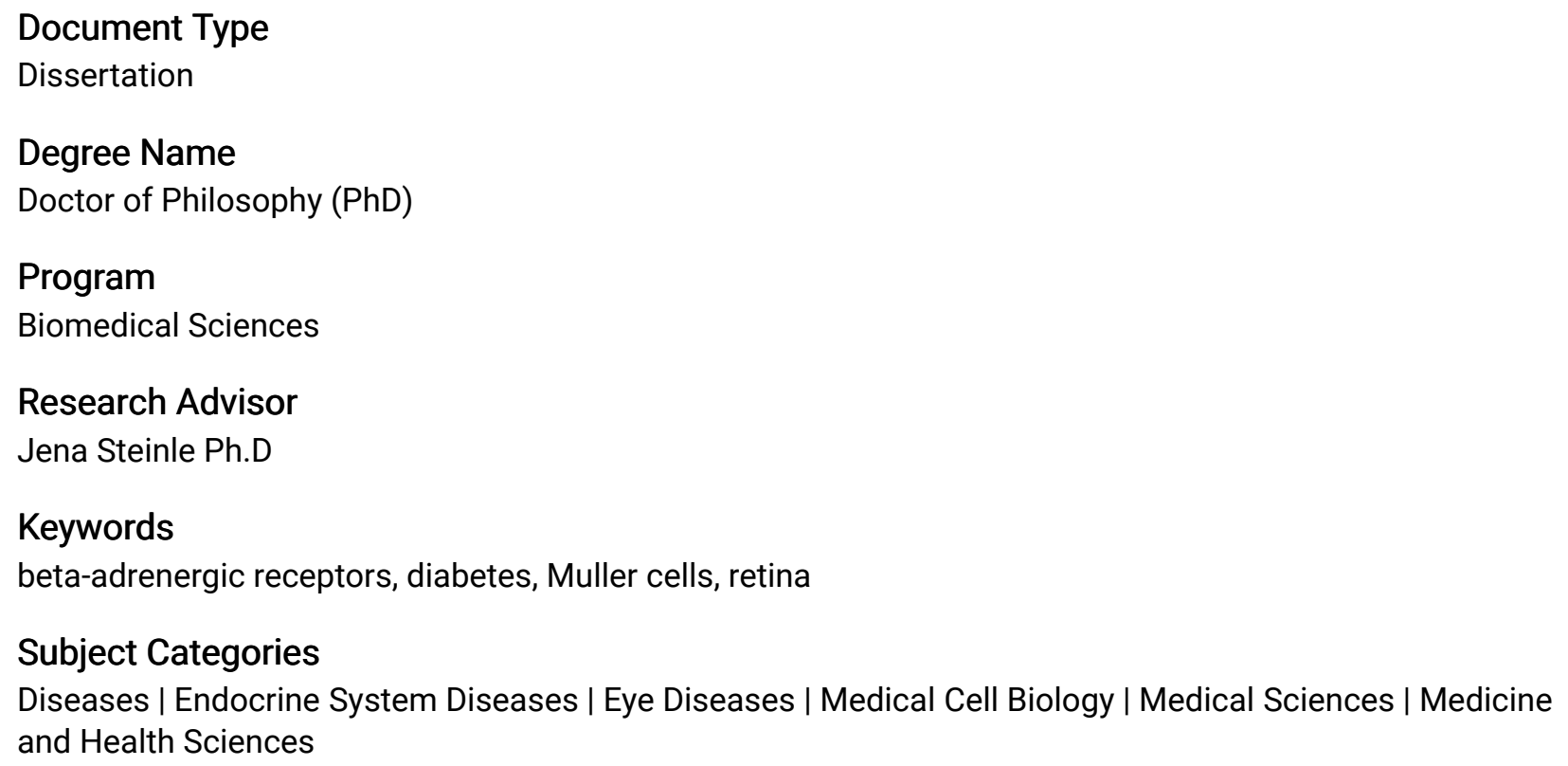




\title{
Beta-2-Adrenergic Receptor Regulates Insulin Signaling to Reduce Cell Death in
} Müller Cells

\author{
A Dissertation \\ Presented for \\ The Graduate Studies Council \\ The University of Tennessee \\ Health Science Center
}

In Partial Fulfillment

Of the Requirements for the Degree

Doctor of Philosophy

From The University of Tennessee

By

Robert Jason Walker

May 2012 
Chapter 2 (C) 2012 by Molecular Vision.

Chapter 3 C 2011 by Investigative Ophthalmology \& Vision Science. All other material (C) 2011 by Jason Walker. All rights reserved. 


\section{DEDICATION}

This dissertation is dedicated to my family who gave me support, advisement, strength, prayer and encouragement in this journey. A special dedication is extended to my parents, Robert and Martha Walker, who instilled me the value of education, perseverance and faith. Finally a special dedication is given to my sister and nephew, Shondra Walker and Kaeden Thigpen for their well wishes, belief, and tolerance of my limited free time. 


\section{ACKNOWLEDGEMENTS}

First, I would like to acknowledge my heavenly father for his grace, mercy, and the blessings that he has bestowed upon me. I would like to acknowledge the excellent mentorship and guidance of Dr. Jena J. Steinle and the initial introduction of research and guidance given by Dr. Troy Stewart. These two individuals instilled me the appetite for knowledge as well as the appropriate time, dedication, patience, and faith to help me matriculate throughout my academic career.

I would also like to acknowledge the support and assistance given to me by NIH, former and present members of the Steinle Lab, especially Kimberly Williams-Guy for her support and advice. I would also like to acknowledge my brothers, Romell Barnes and Edwin Norwood for their support and encouragement throughout this process. I would further like to acknowledge all of my UT family that has supported, encouraged, and advised me during my time as a student. Finally, I would like to thank a dear friend, Harriet Crockett for her support through one of the darkest hours in my life, I am eternally grateful for her support, encouragement, and actions. 


\begin{abstract}
Changes in the diabetic retina likely occur in response to a variety of insults, including high glucose, oxidative stress, and increased levels of inflammatory markers. Müller cells become activated and express increased glial fibrillary acidic protein levels in diabetes. This suggests that these cells are in a reactive state that may alter their regulation of inflammatory markers, glucose transport, oxidative stress, growth factors, and cell survival. During the onset of diabetes, there is a loss of sympathetic nerve activity that takes place in different regions of the body. Previous studies from our lab suggested that loss of sympathetic neurotransmission induces diabetic-like changes to the retina, specifically in Müller cells and endothelial cells.
\end{abstract}

In previous studies, we found that retinal Müller cells possess beta-1 and beta-2-adrenergic receptors, and with those findings we used a non-specific beta agonist, isoproterenol as a treatment to stimulate both receptors. In addition we used a selective beta-2-adrenergic receptor agonist, salmeterol, to selectively stimulate the beta-2-adrenergic receptor in Müller cells. Salmeterol significantly increased tyrosine phosphorylation of the insulin receptor, Akt, and significantly reduced apoptosis in retinal Müller cells. Our data showed that salmeterol reduced TNF- $\alpha$ levels. TNF- $\alpha$ phosphorylates IRS-1 on Ser307 and inhibits insulin signaling. Salmeterol inhibited, TNF- $\alpha$ and thereby increased insulin signal transduction.

Based upon these findings, we generated shRNA against TNF- $\alpha$ and IRS-1. Knockdown of IRS-1 with shRNA significantly increased in cell death compared to retinal Müller cell samples cultured in 5mM glucose alone. However stimulation of beta-2-adrenergic receptor prevented cell death through IRS-1 in a hyperglycemic environment. We demonstrated that knockdown of TNF- $\alpha$ by shRNA significantly reduced the phosphorylation of serine 307 on IRS-1, leading to increased Akt activity. Our results are in agreement with other studies in adipose cells, which found TNF- $\alpha$ to be a negative regulator of the insulin receptor signaling. We believe that these results provide a putative mechanism for the effects of beta-adrenergic receptors in reducing retinal damage in diabetes. These studies will help to further characterize the function of beta-2-adrenergic receptors in the retina and also in a disease state, such as diabetic retinopathy. 


\section{TABLE OF CONTENTS}

CHAPTER 1. GENERAL INTRODUCTION ..............................................................1

Introduction to the Autonomic Nervous System .....................................................

Brief History of Beta-Adrenergic Receptors ............................................................

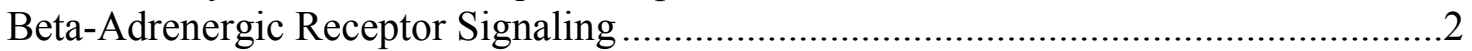

Regulation of Sympathetic Neurotransmission in the Retina ....................................4

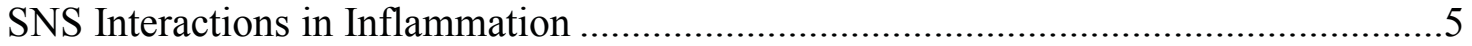

Role of Insulin Receptor Signaling in Retina .........................................................6

Research Objective and Specific Aims....................................................................8

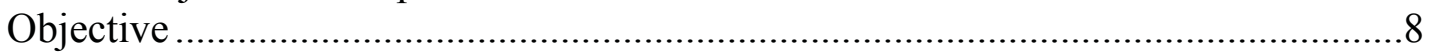

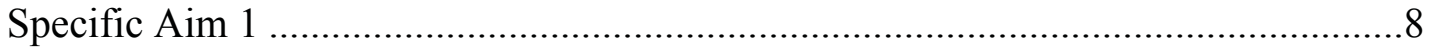

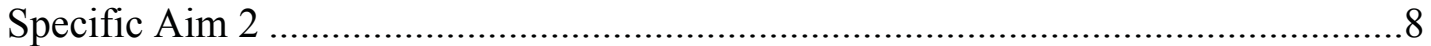

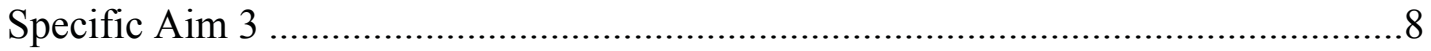

CHAPTER 2. SILENCING OF INSULIN RECEPTOR SUBSTRATE-1

INCREASES CELL DEATH IN RETINAL MÜLLER CELLS ................................9

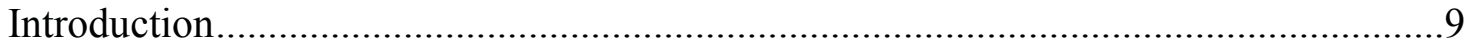

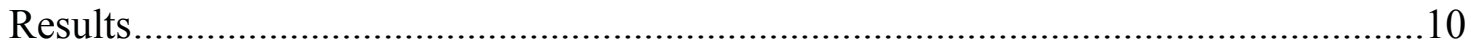

Salmeterol Prevents Phosphorylation of IRS-1 ${ }^{\text {Ser307 }}$ Induced by TNF $\alpha$...................10

Silencing of IRS-1 Decreases Total Akt Levels ..................................................... 10

Loss of IRS-1 Increases Cell Death in Retinal Müller Cells ...................................10

Silencing IRS-1 Increases Cytochrome C levels in Retinal Müller Cells .................14

Absence of IRS-1 Causes Increase in Bax Levels .................................................... 14

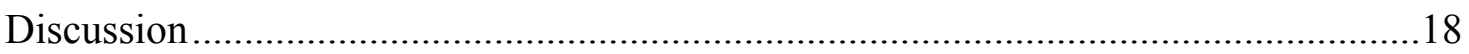

\section{CHAPTER 3. ROLE OF $\beta$-ADRENERGIC RECEPTOR'S REGULATION OF} TNF- $\alpha$ AND INSULIN SIGNALING IN RETINAL MÜLLER CELLS ...................20

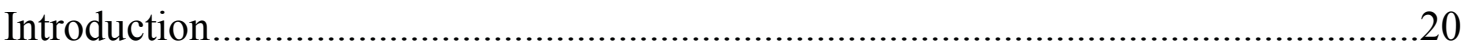

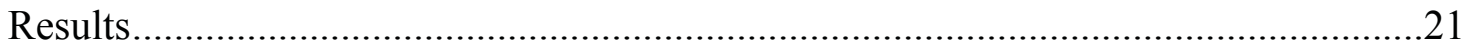

Stimulation of Beta-Adrenergic Receptors Increases Insulin Receptor Signaling ....21

Stimulation of Beta-Adrenergic Receptors Decreases Cleaved Caspase 3 ..............21

Blocking of Beta-Adrenergic Receptor by Selective Inhibitors .............................21

Salmeterol Significantly Reduces TNF- $\alpha$, while Increasing Insulin Receptor and

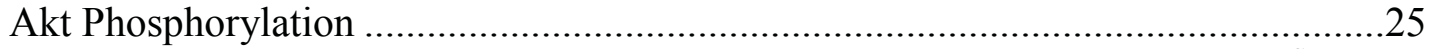

Silencing of TNF- $\alpha$ Plays Critical Role in Phosphorylation of Akt and IRS-1 ${ }^{\text {Ser }}$ 307

TNF- $\alpha$ Is a Mediator of Apoptosis in rMC-1 Cells ...............................................28

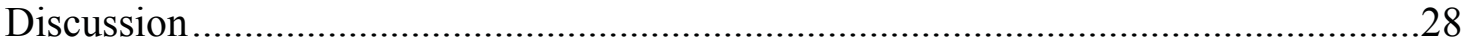

\section{CHAPTER 4. DUAL SIGNALING OF G PROTEIN COUPLED RECEPTORS REDUCES CELL DEATH IN RETINAL MÜLLER CELLS ....................................32}

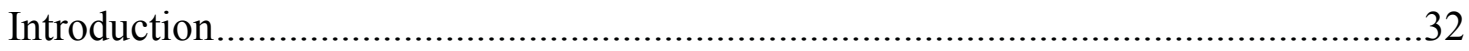

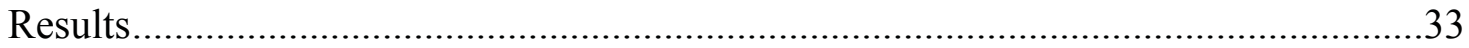

Knockdown of PKA Produces No Significant Changes in Insulin Receptor .............33 
Loss of PKA Decreases Phosphorylation of Akt Levels while Increasing Phosphorylation of IRS-1 ${ }^{\text {Ser } 307}$

Dual Coupling of $\mathrm{G}_{\mathrm{s}} / \mathrm{G}_{\mathrm{i}}$ Decreases Cell Death in Retinal Müller Cells.....................36

Activation of $\mathrm{G}_{\mathrm{i}}$ Does Not Effect Insulin Receptor Phosphorylation in Retinal

Müller Cells

Pertussis Toxin Treatment Causes Increase in Phosphorylation of Akt ....................36

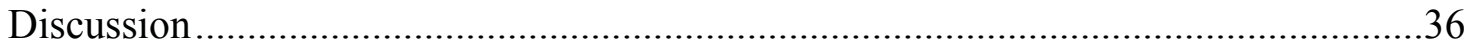

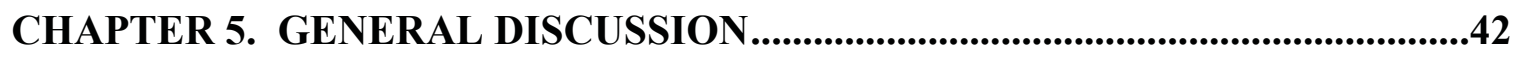

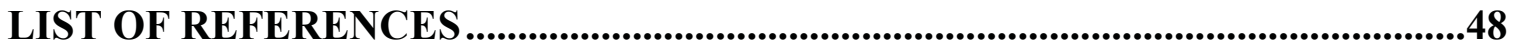

APPENDIX A. MATERIALS AND METHODS................................................ 59

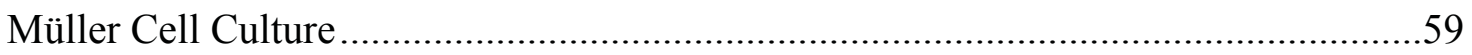

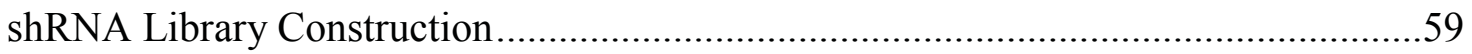

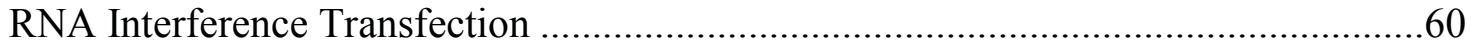

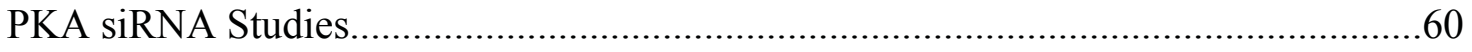

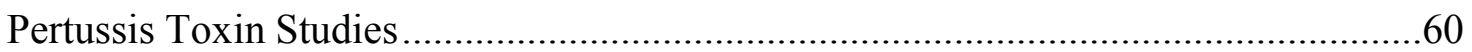

Beta-Adrenergic Receptor Antagonist Treatment ...................................................61

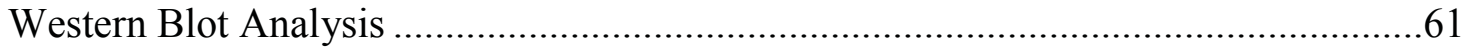

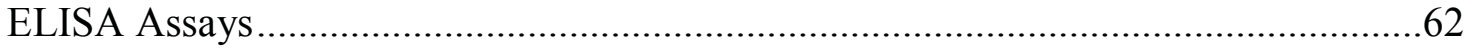

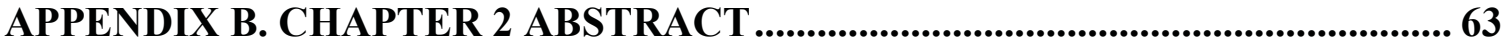

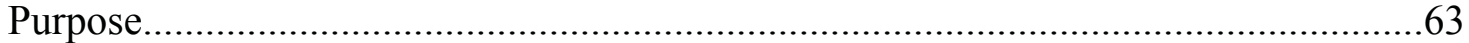

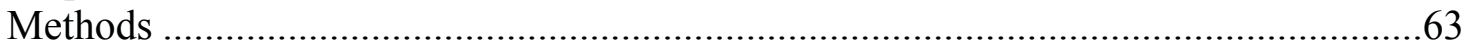

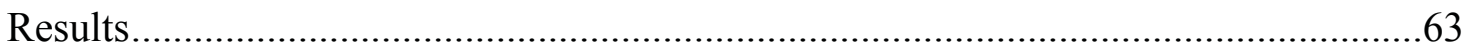

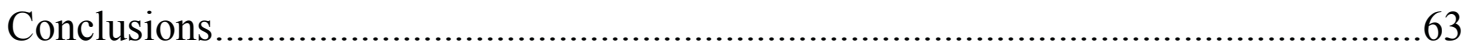

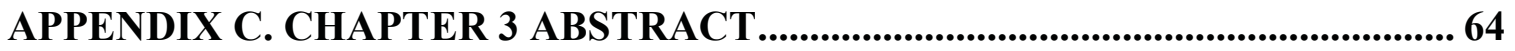

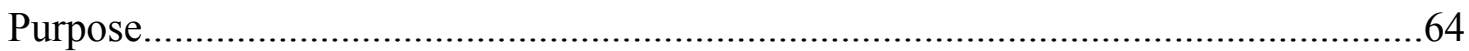

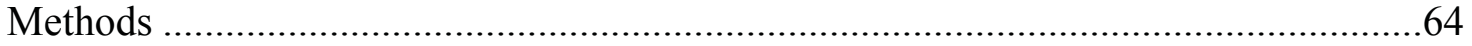

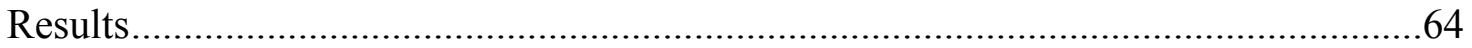

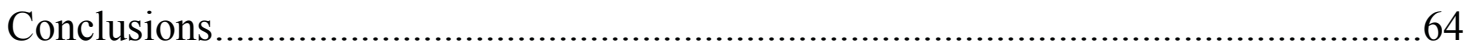

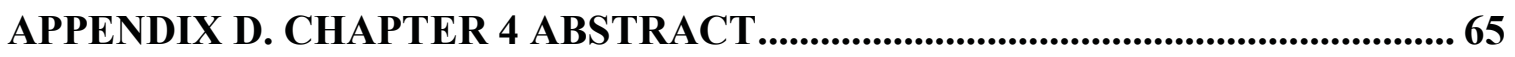

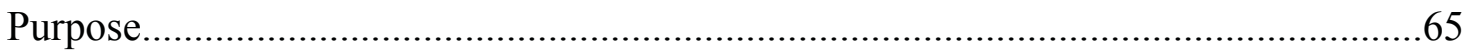

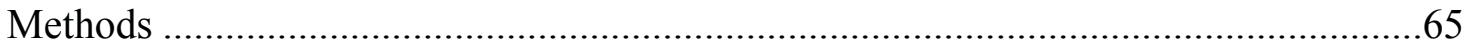

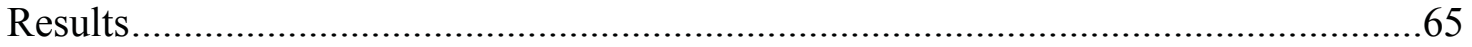

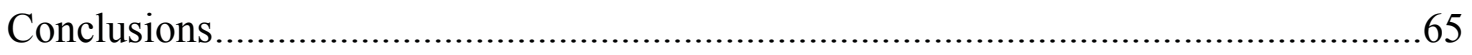

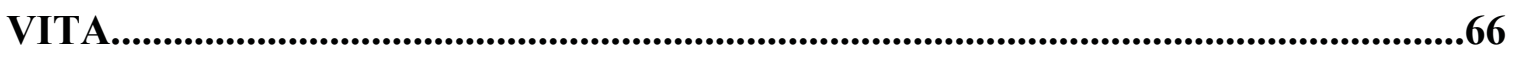




\section{LIST OF FIGURES}

Figure 1-1. Activation of PKA by beta-adrenergic receptors ...................................... 3

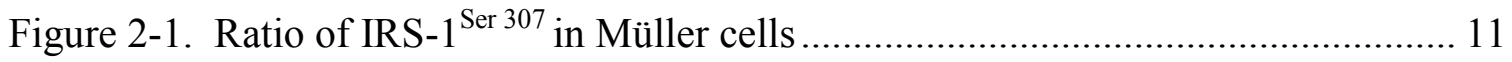

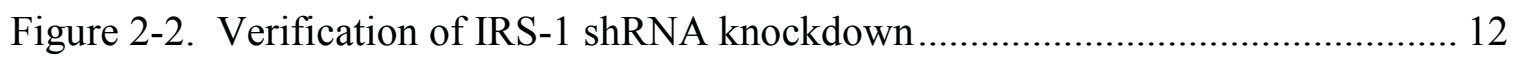

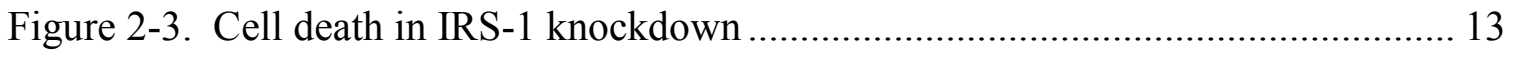

Figure 2-4. Levels of cytochrome C increased in IRS-1 knockdown ........................... 15

Figure 2-5. Bax protein levels increased in IRS-1 knockdown ................................ 16

Figure 2-6. Anti-apoptotic Bcl-xL levels decreased in IRS-1 knockdown..................... 17

Figure 3-1. Treatment with isoproterenol restores phosphorylation of IRB and Akt..... 22

Figure 3-2. Levels of cleaved caspase 3 reduced following treatment .......................... 23

Figure 3-3. Levels of cleaved caspase 3 in retinal Müller cells ................................. 24

Figure 3-4. Stimulation of TNF- $\alpha$ in retinal Müller cells .......................................... 26

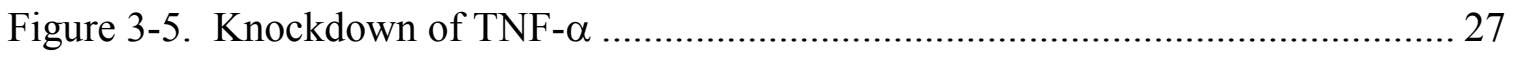

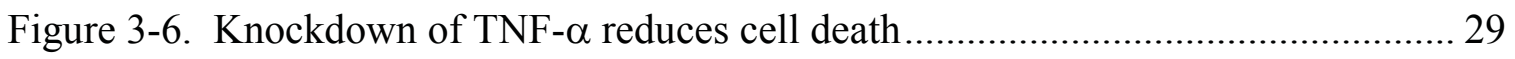

Figure 4-1. Knockdown of PKA shows little change in phosphorylation of insulin

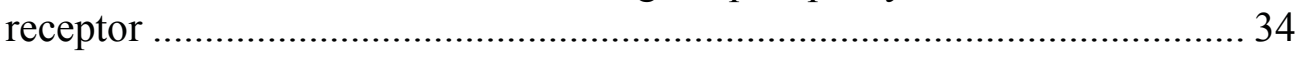

Figure 4-2. PKA siRNA decreases phosphorylation of Akt ..................................... 35

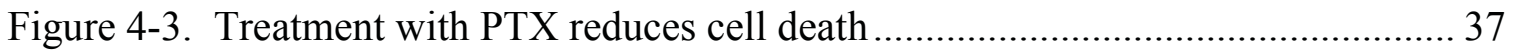

Figure 4-4. PTX treatment shows no effect on phosphorylation of insulin receptor....... 38

Figure 4-5. Treatment with PTX leads to increased Akt phosphorylation ..................... 39 


\section{CHAPTER 1. GENERAL INTRODUCTION}

\section{Introduction to the Autonomic Nervous System}

The autonomic nervous system is an involuntary system that regulates the heart, blood vessels, immune system, lungs, and eye. This system is divided into two subsystems, parasympathetic nervous system and sympathetic nervous system. The parasympathetic nervous system is responsible for the "rest and digest," nonemergency actions throughout the body such as slowing heart rate, pupil constriction, increasing digestion and other opposing actions of the sympathetic nervous system. The sympathetic nervous system is responsible for the "fight or flight" response in times of stress and excitement. These responses are mediated by two endogenous neurotransmitters, norepinephrine, and epinephrine. During times of stress, the adrenal medulla releases epinephrine into the bloodstream causing physical effects such as increases in heart rate, pupil dilation, increase in sweating, etc, while sympathetic nerve terminals release synaptic norepinephrine in the target organs. The action of catecholamines are mediated by alpha and beta-adrenergic receptor that are selectively distributed in all organs of the body.

\section{Brief History of Beta-Adrenergic Receptors}

In 1948, Ahlquist provided the initial characterization of beta-adrenergic receptors. ${ }^{1}$ These investigations led Ahlquist to classify the receptors based upon responses to agonists in different tissues throughout the body. ${ }^{1}$ The adrenergic receptors were classified alpha (excitatory) and beta (inhibitory); the beta-adrenergic receptors received their name based upon the "insensitivity" of these drugs to $\beta$-haloalkylamines. Further work by Land et. al in 1967 duplicated some of the previous work of Ahlquist, by comparing various adrenergic agonists on the stimulation of beta-adrenergic receptors, in various tissues. $^{2}$ Results from these studies led to two different receptor subtypes: beta-1-adrenergic receptor and beta-2-adrenergic receptor. ${ }^{3}$ Studies into the structure of beta-adrenergic receptors revealed that these subtypes of receptors possess an alpha helical membrane-spanning region that contains seven clusters of hydrophobic amino acids. ${ }^{4}$ The beta-1-adrenergic receptor contained 477 amino acid residues compared to the 413 residues of the beta-2-adrenergic receptor. Further studies into similarity of sequence homology between the two subtype of receptors, suggested a 54\% sequence homology in beta- 1 vs. beta- 2 adrenergic receptor. ${ }^{4}$ Since the sequence homology contained a lot of variability between the two subtypes, the author decided to investigate the sequence homology within the transmembrane regions, since this region is believed to be the key to $\mathrm{G}$ protein coupling. The results showed a $71 \%$ transmembrane sequence homology between the two-receptor subtypes. Although amino acid sequences were noticed, none of the differences were specific enough to explain the difference in catecholamine binding affinities.

Additional findings have suggested that each receptor subtype had dominance in different tissues throughout the body. ${ }^{2}$ For example, results suggested that the beta-1 
adrenergic receptor is the dominant receptor in the heart, while beta-2 adrenergic receptor is found to be dominant in the lungs and uterus. ${ }^{1}$ Sensitivity in affinity to epinephrine and norepinephrine is equal for the beta- 1 adrenergic receptor, but the beta- 2 adrenergic receptor has higher affinity and sensitivity to epinephrine versus norepinephrine. ${ }^{5}$ The classification of these two specific beta-adrenergic receptor subtypes is widely accepted today, but additional data indicated that there was an additional adrenergic receptor that did not respond to non-selective agonists and antagonists. The newly found receptor subtype, beta-3 adrenergic receptor, was identified with selective agonists and observed to possess characteristics of the two previously discovered beta-adrenergic receptors. ${ }^{2}$

\section{Beta-Adrenergic Receptor Signaling}

The beta-adrenergic receptors are family A members of the $\mathrm{G}$ protein-coupled receptors (GPCRs) . The activation of beta-adrenergic receptors takes place in a site within the transmembrane region, which allows ligand binding of two neurotransmitters norepinephrine and epinephrine. ${ }^{6}$ Norepinephrine and epinephrine signal through guanine nucleotide binding proteins ( $\mathrm{G}$ proteins) to elicit various cellular actions such as phosphorylation of receptors and activation of various signaling pathways. G proteins consist of three functional subunits, a large alpha subunit, a beta subunit, and a gamma subunit. The beta and gamma subunits are coupled together making them active, while the alpha is alone but is responsible for most of the signaling. The alpha subunit is divided into four families, $\mathrm{Gs}, \mathrm{Gi}, \mathrm{Gq}$, and $\mathrm{G}_{12}$, based upon sequences of amino acids rather than functional characteristics. Signaling through the $\mathrm{G}$ proteins takes place upon stimulation of a receptor (in this case the beta-adrenergic receptor) by a neurotransmitter, or agonist, which would activate the G-protein. Activation of G-protein will initiate exchange of GDP for GTP to activate the alpha subunit and separate from the coupled beta-gamma subunits. Once the GTP is exchanged, further signaling is carried out by the G-alpha and GTP complex, which propagates the signal to the effector molecule, adenylyl cyclase ${ }^{7,8}$ Enzymatic activity of adenylyl cyclases is commonly stimulated by the alpha subunit of the Gs protein, which leads to conversion of ATP to the second messenger, 3'-5' -cyclic AMP (cAMP).,

This second messenger, cAMP activates protein kinase A (PKA) to elicit its biological effects on a cellular level (Figure 1-1). The activity of PKA results from a conformational changes to its structure, which consists of two R subunits (regulatory) and two $\mathrm{C}$ subunits (catalytic). The $\mathrm{C} 2 \mathrm{R} 2$ structure of PKA is inactive because the $\mathrm{C}$ subunit is bound to the R subunit, separating the holoenzyme to make PKA active. ${ }^{7,8}$ The active form of PKA phosphorylates many substrates, such as cAMP responsive element binding protein (CREB). ${ }^{9}$ Phosphorylation of CREB by PKA at Ser 133 activates CREB and allows CREB to bind cAMP-responsive element (CRE). ${ }^{9}$ At Ser 133, CREB binds the KIX domain of CREB binding protein (CBP) to serve as a coactivator. ${ }^{9}$ Recruitment of $\mathrm{CBP}$ assists with transcription by forming the transcription initiation complex at the initiation site for CRE containing portions of a particular gene. ${ }^{9}$ Recruitment of CBP at Ser 133 and activation of CREB are involved in transcription in a number of pathways, including the P42/44 MAP kinase, PI3K/AKT, and matrix metalloproteinases pathways. ${ }^{10}$ 


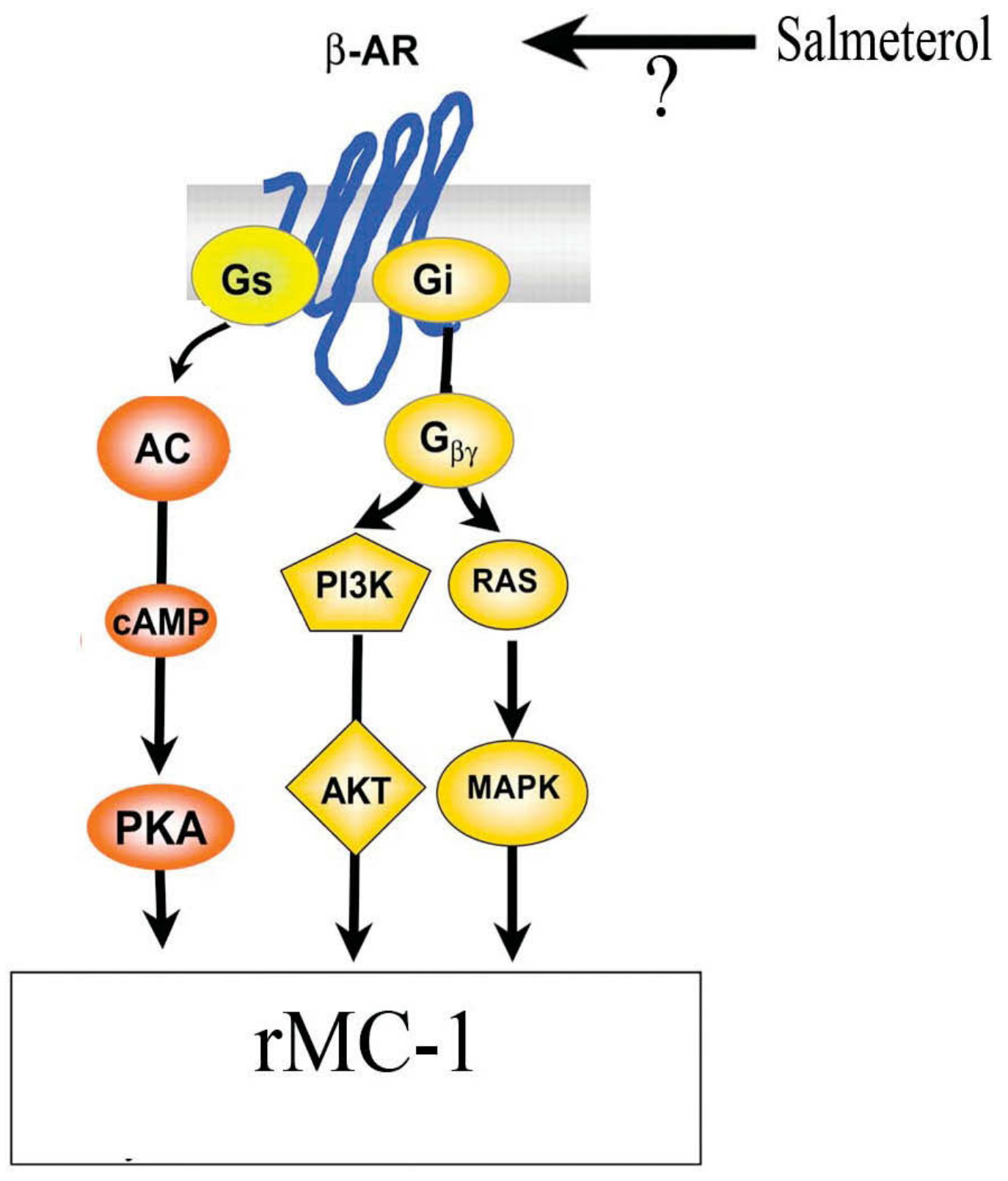

Figure 1-1. Activation of PKA by beta-adrenergic receptors

Schematic illustrating proposed signaling of activation of PKA by $\beta$-adrenergic receptors $(\beta-\mathrm{AR})$ following treatment with agonist in retinal Müller cells. Adapted with permission. Pepe S, van den Brink OWV, Lakatta EG, Xiao R-P. Cross-talk of opioid peptide receptor and beta-adrenergic receptor signalling in the heart. Cardiovascular Research 2004;63:414-422. ${ }^{14}$ 
These pathways have all been implicated in diabetic retinopathy, involving angiogenic effects, stimulation of growth factors, and breakdown of the blood retinal barrier. ${ }^{11-13}$

PKA activity is regulated by phosphorylation of proteins on a subcellular level. ${ }^{6,15-17}$ Target and choices of protein phosphorylation are determined and influenced by the localization of the targeted substrate and enzyme within a specific cell. In order for proper protein phosphorylation and other protein interactions to take place, the substrate and the enzyme must be in the same proximity of one another within the cell. $^{6,15-17}$ Regulation on a subcellular level of PKA is dependent upon the regulatory subunits, which bind to various proteins (scaffolding, anchoring, and adaptor) at specific sites within the cell. Various studies have suggested that targeting the isoforms of PKA is done by A-Kinase Anchor Proteins (AKAPs). ${ }^{7,18-20}$ AKAPs consist of more than 50 members that function to target substrates to certain subcellular sites. ${ }^{7,18-20}$ AKAPs contain a conserved motif that possesses high affinity binding to the regulatory subunit of PKA. Binding of the RII subunit to AKAP creates an AKAP-PKA complex that anchors and targets PKA within the cell, In addition to binding PKA, AKAPs bind other kinases, such as PKC and phosphatases. The complexes establish a foundation for synchronization of enzyme activities, in time and space. ${ }^{7,18-20}$

After signals have been tranduced through protein phosphorylation via cAMP-PKA and AKAP pathways, the signal and response become weakened. This weakened signal is attributed to the beta-adrenergic receptors that are still being stimulated by binding of a agonist, that are now undergoing a process of desensitization. This process of homologous receptor desensitization is initiated by phosphorylation of a G protein coupled receptor protein kinase (GRK). ${ }^{6,15-17}$ The family of GRK consists of four members, GRK2 (beta-adrenergic receptor kinase 1), GRK5, GRK3 (beta-adrenergic receptor kinase 2), and GRK6. ${ }^{6,15-17}$ Phosphorylation of GRK in the C-terminal region of the beta-adrenergic receptor causes the attachment of beta arrestin, disrupting signaling of $\mathrm{G}$ protein. ${ }^{6,15-17}$ Beta arrestins also recruit clathrins to initiate the formation of clathrin-coated vesicles. Internalization causes the beta-adrenergic receptor to become dephosphorylated; at this point the receptor will be directed back to the cell

membrane. ${ }^{6,15-17}$ The internalization of the beta-adrenergic receptor functions to disrupt signaling following extended periods of agonist bound stimulation.

\section{Regulation of Sympathetic Neurotransmission in the Retina}

In diabetes there is a loss of sympathetic nerve activity leading to dysfunction of the kidneys, heart, and peripheral vasculature. ${ }^{21}$ For example, loss of sympathetic neurotransmission in the pancreas has been shown to inhibit release of insulin from pancreatic beta cells in response to high glucagon levels. ${ }^{22}$ Sympathetic nerves induce dilation of the pupils in the eye, by stimulation of ciliary nerves. ${ }^{23}$ Damage to these sympathetic nerves causes ptosis (droopiness of the eyelid), primarily seen in Horner's syndrome. ${ }^{24}$ Other investigations of sympathetic neurotransmission in the eye, such as in the retina, have been controversial. 
Previous investigations by Laties and Jacobowitz (1966) did not observe sympathetic innervation in the retina by immunohistochemical analysis. ${ }^{25}$ However, Furukawa (1987), using both immunohistochemical and transmission and scanning electron microscopy, demonstrated that the retina does receive sympathetic innervation. ${ }^{26}$ Further studies have shown that sympathetic innervation from the superior cervical ganglion is responsible for the ocular blood flow in choroidal and retinal blood vessels in hypertensive cats. ${ }^{27}$ Results from these studies demonstrate that sympathetic nerves are likely present in retina. ${ }^{10}$

Loss of sympathetic neurotransmission in the retina could be responsible for some of the changes that take place in diabetic retinopathy. Past investigations in our lab have shown that surgical removal of the superior cervical ganglion, which eliminates sympathetic neurotransmission to all cranial targets, can produce classic hallmarks of diabetic retinopathy such as pericyte dropout, basement membrane thickening, and Müller cell activation. ${ }^{28,29}$ In addition, we have shown that loss of sympathetic neurotransmission can lead to loss of cells in the ganglion cell and outer nuclear layers. ${ }^{30}$

\section{SNS Interactions in Inflammation}

One potential mechanism by which the sympathetic nervous system might be involved in diabetes is decreasing inflammatory markers. Inflammation is often associated with increased blood flow, swelling, and permeability of the vasculature, and increase in inflammatory markers in cytokine activity. ${ }^{31}$ Sympathetic neurotransmitters such as norepinephrine are able to decrease inflammatory characteristics such as phagocytosis, apoptosis, and natural killer cell activity, as well as inhibiting production of certain inflammatory markers. One key inflammatory marker is TNF- $\alpha$, which is produced in a variety of cells, including macrophages, astrocytes, microglia, and reactive retinal Müller cells. ${ }^{32}$ In rheumatoid arthritis, TNF- $\alpha$ and another inflammatory marker, IL-1 $\beta$ are believed to be upregulated in T-cells. ${ }^{33}$ Studies have shown that T-cells secrete IL- $1 \beta$ and TNF- $\alpha$ in response to a stress in this condition. ${ }^{33}$ Cyclic AMP and PKA decreases production of inflammatory cytokines T-cells. ${ }^{33}$ Previous research has shown that signaling in rheumatoid arthritis is attributed to the beta-2 adrenergic receptor subtype. ${ }^{33}$ Further studies suggest that treatment with a beta- 2 adrenergic receptor agonist, salmeterol, is able to block T-cell activation, which blocks production of inflammatory markers TNF- $\alpha$ and IL- $1 \beta .^{33}$

In ocular inflammation, TNF- $\alpha$ may be involved in induced uveitis, retinal degeneration, glaucoma, and diabetic retinopathy. ${ }^{34}$ Some of the effects of TNF- $\alpha$ include cellular apoptosis and crosstalk with other inflammatory markers, such as iNOS, ICAM-1, and prostaglandins. Specifically, in glaucoma, reactive Müller cells rapidly increase production of TNF- $\alpha$, while other retinal cells are devoid of this cytokine. ${ }^{34}$ In diabetes, TNF- $\alpha$ was significantly increased in diabetic rats as compared to control rats. ${ }^{35}$ This finding is in agreement with other data that suggest that inflammation may occur in response to high glucose in retinal cells. ${ }^{35}$ In human diabetic vitreous samples, increased levels of TNF- $\alpha$ and IL- $1 \beta$ were detected. ${ }^{35}$ 
Beta-adrenergic receptor signaling may inhibit cytokine release in a hyperglycemic environment. Müller cells are activated in a hyperglycemic environment, and that beta-adrenergic receptors on these cells may regulate cytokine activities. In rat Müller cells significantly upregulated TNF- $\alpha$ as well as other cytokines such as IL-1 $\beta$, and iNOS in $25 \mathrm{mM}$ glucose. ${ }^{36}$ After treatment with isoproterenol, Western blot and ELISA analysis revealed that protein levels of TNF- $\alpha$, IL-1 $\beta$, and iNOS were significantly decreased as compared to control cells. ${ }^{36}$ Literature has shown that with the onset of diabetes, an inhibitory mechanism occurs in which phosphorylation by IRS $-1^{\text {Ser307 }}$ is induced by the upregulation of inflammatory cytokine, TNF- $\alpha$. This event can play an inhibitory role in insulin receptor signal transduction, leading to the increased apoptosis noted in the diabetic retina.

\section{Role of Insulin Receptor Signaling in Retina}

Insulin is a hormone that starts out as a peptide, preproinsulin, which consists of 110 amino acids. ${ }^{37}$ The first 24 amino acids are the pre form, which guides the peptide for cleavage in the endoplasmic reticulum. ${ }^{38}$ Following cleavage, the proinsulin portion is left and form the A and B chains, both of which are stored in the beta cells of the pancreas. ${ }^{38}$ Insulin synthesis begins when disulfide bridges link the A and B chains.

The action of insulin is mediated by binding of insulin to the insulin receptor, which is located on the cell membrane. ${ }^{38}$ This receptor is made up of two alpha subunits and two beta subunits, which are connected by disulfide bonds. ${ }^{37,39}$ The actions of insulin are initiated when the receptor becomes bound on the alpha subunits and this binding of receptor causes phosphorylation of tyrosine kinases on the beta subunits inducing a conformational change of the receptor. ${ }^{37,39}$ The beta subunits of the insulin receptor become phosphorylated due to the binding of insulin, initiating a conformational change. ${ }^{37,39}$ Following tyrosine phosphorylation of the beta-subunit of the insulin receptor, one of the 30 or more tyrosine or serine/threonine residues on the insulin receptor substrate (IRS) complex becomes phosphorylated. ${ }^{37,39}$ Following insulin stimulation, phosphorylation of Akt on Ser 473 will occur downstream of the IRS complexes to inhibit apoptosis.

Das et al. (1984) suggested the possibility of insulin being produced in other tissues beyond the beta cells of the pancreas. ${ }^{40}$ In these studies, using insulin antibodies in rodent retinal glial cells, Das found that these cells could produce insulin and that insulin receptors were present in glial cells, likely Müller cells. ${ }^{40}$ From these initial studies, recent results have further suggested that receptors for insulin are present in the eye, specifically the retina. ${ }^{41-44}$ Further studies by Budd (1987) found the presence of the precursor of insulin, preproinsulin, in mRNA from an intact rat retina. ${ }^{45}$ These studies suggest that the retina has might or is capable of synthesizing insulin and activate insulin receptor signal transduction.

Other investigations using both ex vivo and in vivo methods were initiated to better understand the mechanisms of insulin action in the retina. Gardner et al. (2006) 
have shown that insulin is able to decrease apoptosis induced by serum starvation using rat retinal explants. ${ }^{37}$ This study revealed that insulin inhibited the cleavage of caspase 3 , which decreased apoptosis and increased cell survival. ${ }^{37}$ This reduction of cell death was suggested to be modulated by an Akt- mediated pathway, since inhibitors to PI3K also inhibited the actions of insulin. ${ }^{37}$

While insulin signaling in the retina has been previously investigated, few studies have targeted the role of beta-adrenergic receptor regulation of insulin signaling in the retina. However, there is abundant literature from other cell types describing an interaction between insulin and beta-adrenergic receptor signaling, which appears to be dependent on the glycemic environment of the cells in question. In vascular smooth cells cultured in normoglycemic conditions, insulin can augment beta-adrenergic receptor signaling, while insulin can inhibit beta-adrenergic activation of PKA in cells cultured in high glucose conditions. ${ }^{46,47}$

My dissertation work investigates the interactions between insulin signaling and the beta-2-adrenergic receptor in retinal cells in both normal glycemic and hyperglycemic conditions in retinal Müller cells. We have previously shown that the Müller cells possess beta-1 and beta-2-adrenergic receptors. The goal of this work was to identify the dominant beta-adrenergic receptor present on Müller cells to allow for more detailed analysis of subtype specificity in beta-adrenergic receptor regulation of insulin signaling.

We have shown that Müller cells display an increase in various inflammatory markers; specifically TNF- $\alpha$ in a hyperglycemic environment and that treatment with isoproterenol, a non-specific beta-adrenergic receptor agonist, decreases levels of TNF- $\alpha$. Previous findings in adipose tissue cells, suggest that TNF- $\alpha$ negatively regulates insulin receptor signaling by phosphorylating IRS-1Ser 307 to inhibit insulin action, and decreasing the phosphorylation of Akt. Additionally, TNF- $\alpha$ activates JNK, which is also known to phosphorylate IRS-1Ser 307 in adipose tissue. ${ }^{31}$ This event can play an inhibitory role in insulin receptor signal transduction by potentially leading to the increased apoptosis noted in the diabetic retina.

To address this question, we use selective antagonists and agonists for both beta-1 and beta-2-adrenergic receptors on Müller cells followed by a comparison of the affect of each drug to previous responses of isoproterenol treatment on cleaved caspase 3 levels. These findings suggest that the beta-2-adrenergic receptor is the dominant receptor subtype to mediate insulin receptor signaling on Müller cells. This research presented here will dissect the mechanisms by which beta-adrenergic receptors regulate TNF- $\alpha$ and insulin receptor actions in Müller cells. Our hypothesis is that beta-adrenergic receptors will decrease TNF- $\alpha$, which will increase insulin receptor signaling. These results are invaluable in understanding of the critical role of insulin in diabetic retinopathy. 


\section{Research Objective and Specific Aims}

\section{Objective}

Diabetic retinopathy causes loss of sympathetic neurotransmission and produces significant changes in the retina, including vascular, glial, and neuronal changes that occur during the progression of diabetic retinopathy. Based on this work, our conceptual hypothesis is that loss of sympathetic neurotransmission leads to decreased insulin signaling and increased apoptosis in the retina. The overall objective of this project is to define the mechanisms by which sympathetic neurotransmission modulates insulin signaling and apoptosis in the retina, specifically in retinal Müller cells.

\section{Specific Aim 1}

The first aim of this dissertation was to determine the mechanisms by which beta-adrenergic receptors modulate insulin signaling in retinal Müller cells.

\section{Specific Aim 2}

The second aim of this dissertation was to determine how beta-adrenergic receptor mediated regulation of insulin signaling inhibits apoptosis.

\section{Specific Aim 3}

The third aim of this dissertation was to determine which $\mathrm{G}$ protein is necessary to regulate insulin receptor actions in Müller cells following stimulation with salmeterol. 


\section{CHAPTER 2. SILENCING OF INSULIN RECEPTOR SUBSTRATE-1 INCREASES CELL DEATH IN RETINAL MÜLLER CELLS*}

\section{Introduction}

Over the years, it has been widely accepted that changes that occur in the diabetic retina occur in response to a variety of insults, including high glucose, oxidative stress, and increased expression of inflammatory markers. ${ }^{31,49-58}$ During the initial stages of diabetic retinopathy, Müller cells become activated and express increased glial fibrillary acidic protein (GFAP) levels in diabetes. ${ }^{52,53,58-62}$ This increase in GFAP levels signals a transition of Müller cells from a quiescent to a reactive state, causing a dysfunction in the regulation of inflammatory markers, glucose transport, oxidative stress, growth factors, and cell survival. ${ }^{52,53,58,62-65}$ In diabetic retinopathy, the regulation of insulin signaling, specifically that of insulin receptor substrate 1 (IRS-1), is not well understood. IRS-1 is a $180 \mathrm{kD}$ downstream substrate of the insulin receptor and plays a central role in both insulin and insulin-like growth factor (IGF-1) signaling. ${ }^{66-70}$ IRS-1 has been shown to have numerous sites for phosphorylation of serine, threonine, and tyrosine, with some sites serving to propagate insulin/IGF-1 receptor signaling, while other residues inhibit insulin/IGF-1 signaling. Tyrosine phosphorylation of IRS-1 is known to be an important step in the propagation of insulin/IGF-1 signal, while the role of serine and threonine phosphorylation of IRS-1 has recently become of more significance as a component of insulin resistance, as decreased insulin/IGF-1 signaling is likely a key factor in diabetes. ${ }^{66-70}$ One of the serine residues on IRS-1 that has been suggested as serving an inhibitory role in insulin signaling is serine $307 .^{66,70,71}$ Previous studies have shown that increases in the phosphorylation of IRS-1 $1^{\text {Ser } 307}$ causes decreased insulin receptor signaling, resulting in increased in apoptosis in various tissues throughout the body. ${ }^{70-78}$

In vitro and in vivo studies have shown that prolonged exposure to a hyperglycemic environment produces a number of cellular changes, including increased apoptosis. ${ }^{79,80}$ Normal regulation of cell death in the mitochondria is tightly controlled by the Bcl-2 family, both pro- and anti- apoptotic members. ${ }^{57,81-86}$ In a disease, such as diabetic retinopathy, where the hyperglycemic environment causes cellular stress and damage, Bax, a member of the Bcl-2 family, can become activated and form pores as a passage for other pro-apoptotic proteins to be released. ${ }^{57,81-86}$ Release of proteins, such as cytochrome $\mathrm{C}$, along with increased Bax levels results in cell death through increased levels of key caspases. In contrast, Bcl-xL, an anti-apoptotic member of the Bcl-2 family, is known to prevent cell death by inhibiting activation of the pro-apoptotic proteins. ${ }^{82,84-86}$ These changes have been well studied in other diseases, as well as other cell types in diabetic retinopathy. ${ }^{81,83}$ However, the regulation of apoptotic proteins in

*Source: Reprinted with permission. Walker RJ, Anderson NM, Bahouth S, Steinle JJ. Silencing of insulin receptor substrate-1 increases cell death in retinal Müller cells. Molecular Vision 2012;18: 271-279. ${ }^{48}$ 
retinal Müller cells is not well characterized. A potential role for IRS-1 in this pathway in the regulation of Bax, cytochrome $\mathrm{c}$, and Bcl-xL has also not been investigated.

In this investigation, we hypothesize that silencing the expression of IRS-1 will demonstrate that IRS-1 directly regulates specific apoptotic markers in retinal Müller cells. Additionally, since we have previously demonstrated that beta-adrenergic receptors can decrease TNF $\alpha$ levels, ${ }^{29}$ and TNF $\alpha$ is known to increase IRS- $1^{\mathrm{Ser} 307}$, we hypothesize that salmeterol, a beta-2-adrenergic receptor agonist, requires IRS-1 actions to decrease apoptosis of retinal Müller cells.

\title{
Results
}

\section{Salmeterol Prevents Phosphorylation of IRS-1 ${ }^{\text {Ser307 }}$ Induced by TNF $\alpha$}

\author{
It is known that TNF- $\alpha$ preferentially phosphorylates IRS-1 ${ }^{\text {Ser } 307}$ in other cell \\ types; $;^{70,73,74,77,78}$ we wanted to see if the same mechanism occurs in retinal Müller cells. \\ Following treatment with salmeterol, Western blot analysis revealed that phosphorylation \\ of IRS-1 ${ }^{\text {Ser307 }}$ was significantly decreased as compared to cells in $25 \mathrm{mM}$ glucose alone or \\ with TNF- $\alpha$ only treatment (Figure 2-1) $(* p<0.05$ vs. not treated, $\# p<0.05$ vs. TNF- $\alpha$ \\ alone).
}

\section{Silencing of IRS-1 Decreases Total Akt Levels}

Previous data has shown that significant increases in tyrosine phosphorylation of insulin receptor signals downstream through IRS-1 to increase Akt phosphorylation. ${ }^{73,74}$ Knockdown of IRS-1 with shRNA (Figure 2-2A) $(* p<0.05$ vs. $25 \mathrm{mM}$ Glucose showed a significant decrease in total Akt levels (Figure 2-2B) $\left({ }^{*} \mathrm{p}<0.05\right.$ vs. $25 \mathrm{mM}$ Glucose cultured in a hyperglycemic environment). These results suggest that IRS-1 signals to Akt in retinal Müller cells.

\section{Loss of IRS-1 Increases Cell Death in Retinal Müller Cells}

Treatment of cells with salmeterol alone prevented cell death in retinal Müller cells (Figure 2-3) $(p<0.05$ vs. $25 \mathrm{mM}$ Glucose). Cell death analyses showed a significant increase in cell death in response to silencing of IRS-1 in cells cultured in high glucose as compared to the normal glucose control group (Figure 2-3) (\#p $<0.05$ vs. $5 \mathrm{mM}$ Glucose). Salmeterol + IRS-1 shRNA showed a significant increase in cell death compared to salmeterol alone (Figure 2-3) ( $\$ \mathrm{p}<0.05$ vs. salmeterol alone), suggesting that beta-adrenergic receptors signal through IRS-1 to reduce cell death in retinal Müller cells. 


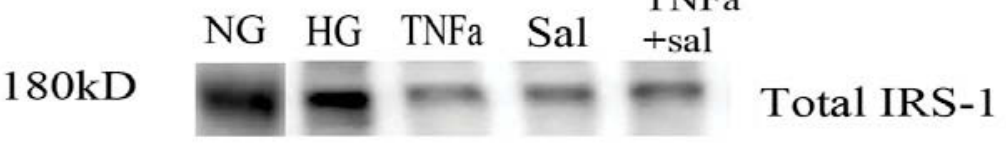

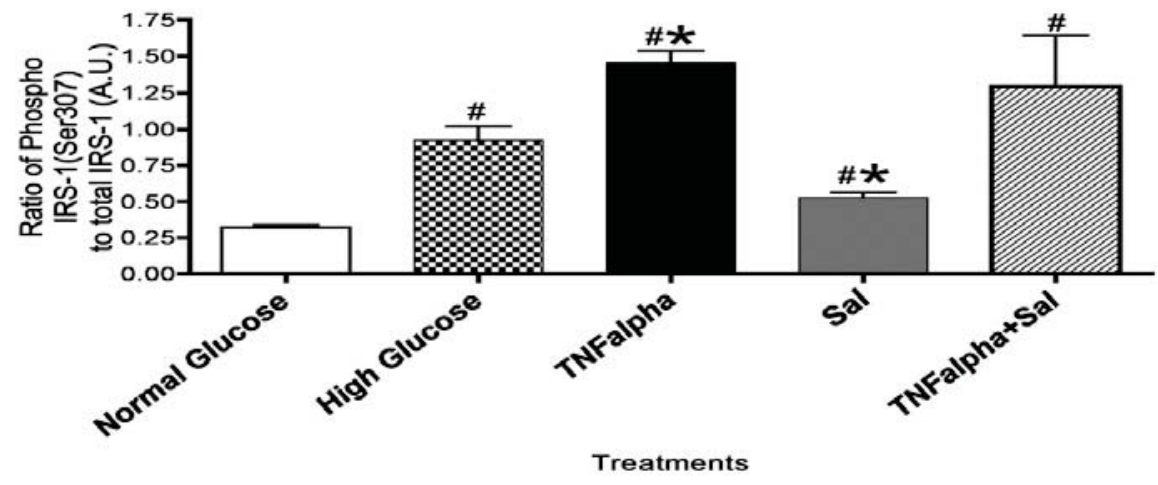

Figure 2-1. Ratio of IRS-1 ${ }^{\text {Ser } 307}$ in Müller cells

Phosphorylation of IRS-1 ${ }^{\text {Ser } 307}$ is significantly increased in Müller cells following treatment with TNF $\alpha$, but treatment with beta-2-adrenergic receptor agonist, salmeterol significantly decreases phosphorylation levels. Significance was determined by one-tailed, non-parametric Mann-Whitney test on Western blot data $\left({ }^{*} p<0.05\right.$ vs. High Glucose, $n=4, \# \mathrm{p}<0.05$ vs. Normal Glucose, $n=4)$. 
A.
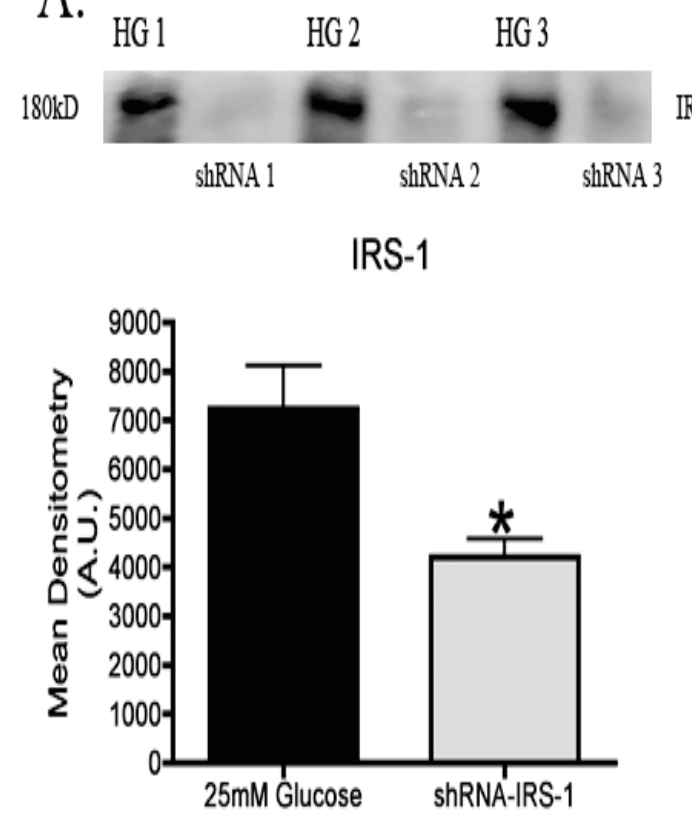

B.

HG $1 \quad$ HG2 HG3

RS-1 60kD

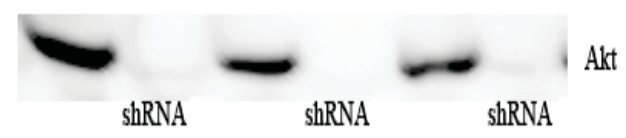

Akt

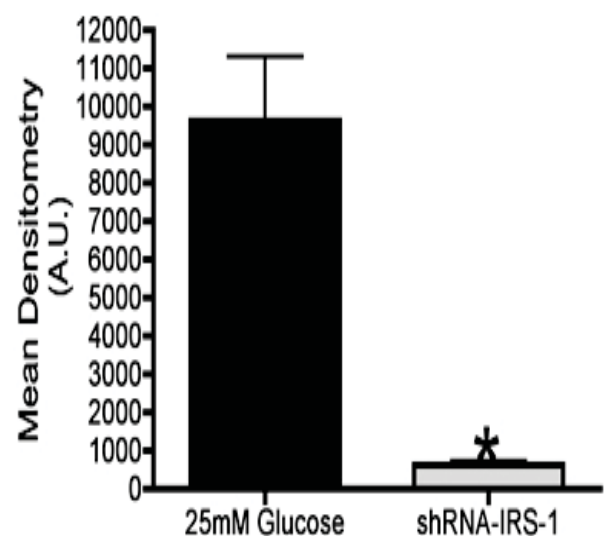

Figure 2-2. Verification of IRS-1 shRNA knockdown

(A) Mean densitometry and representative blot of IRS-1 levels following transfection of shRNA (IRS-1) in rat Müller cells. (B) Mean Densitometry of Akt levels following transfection of shRNA (IRS-1) in Müller cells. Significance was determined by Mann-Whitney test ( ${ }^{*} \mathrm{p}<0.05$ vs. $\left.25 \mathrm{mM}, n=5\right)$. 


\section{Cell Death}

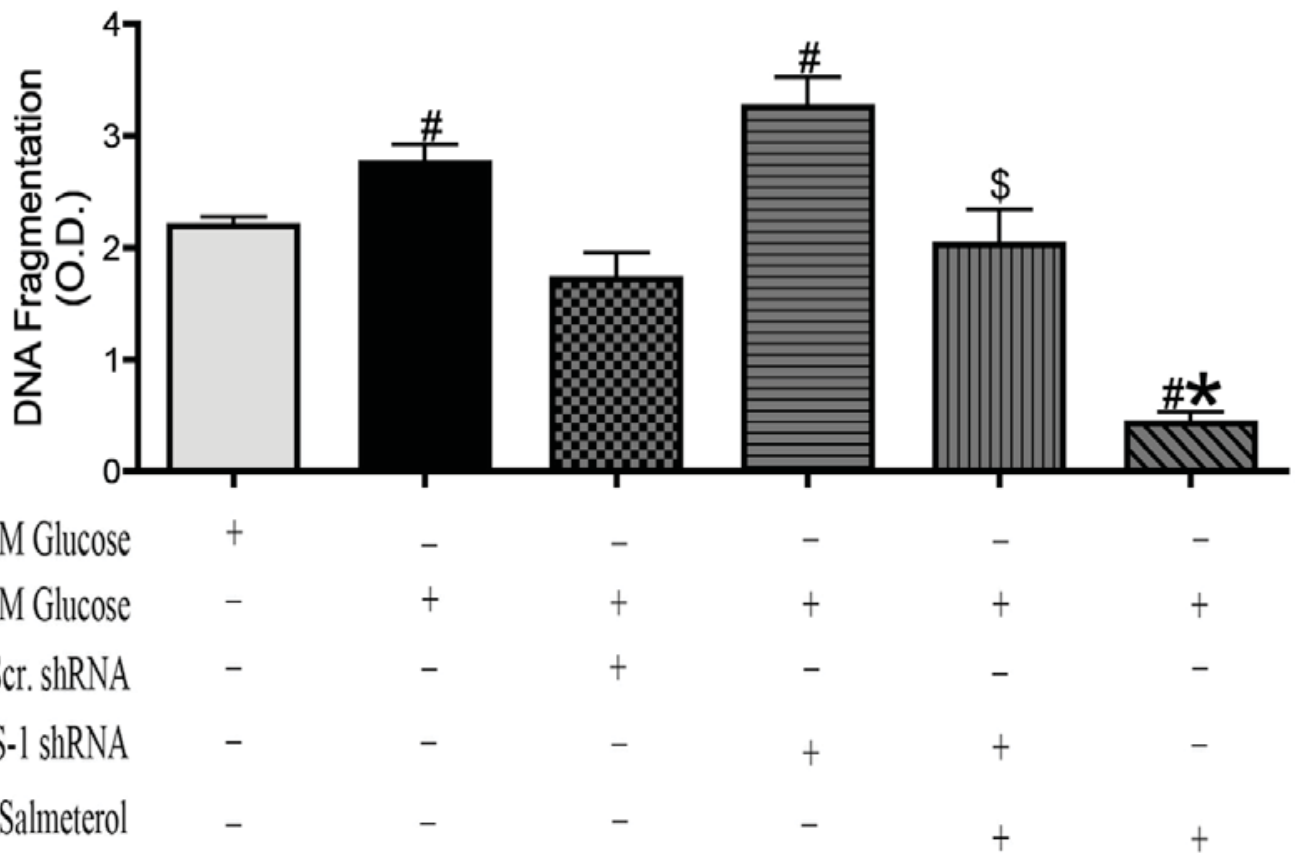

\section{Figure 2-3. Cell death in IRS-1 knockdown}

Cell death ELISA of rat Müller cells transfected with IRS-1 shRNA alone and IRS-1 shRNA + beta-2-adrenergic receptor agonist, salmeterol (SALM) for 6 hours. Transfection with IRS-1 shRNA significantly increased cell death levels vs. $5 \mathrm{mM}$ Glucose. Treatment with salmeterol alone in Müller cells significantly decreased levels of cell death as compared to either $5 \mathrm{mM}$ Glucose or $25 \mathrm{mM}$ Glucose. Statistical significance was determined Mann-Whitney test $(* \mathrm{p}<0.05$ vs. $25 \mathrm{mM}$ Glucose, $\# \mathrm{p}<0.05$ vs. $5 \mathrm{mM}$ Glucose, $\$ \mathrm{p}<0.05$ vs. salmeterol $n=5$ for ELISA assay). 


\section{Silencing IRS-1 Increases Cytochrome C levels in Retinal Müller Cells}

Previous studies have suggested the mitochondria as a key regulator of apoptosis, with excess production of superoxides within the mitochondria initiating cytochrome $\mathrm{c}$ release to the cytosol to begin the cascade of apoptotic signaling. ${ }^{82,84-86}$ Our current investigation shows that prolonged exposure of retinal Müller cells to hyperglycemia results in excess release of cytochrome $\mathrm{C}$ when compared to retinal Müller cells cultured in normal glycemic conditions (Figure 2-4) $(* p<0.05$ vs. $5 \mathrm{mM}$ Glucose). Western blot analysis further shows that salmeterol alone treatment significantly reduced cytochrome $\mathrm{C}$ levels, with the effect lessened when salmeterol was combined with IRS-1 shRNA (Figure 2-4) ( $\$ \mathrm{p}<0.05$ vs. salmeterol alone). Taken together, these results suggests that active IRS-1 is required for salmeterol to reduce cytochrome $\mathrm{C}$ levels in retinal Müller cells cultured in a hyperglycemic environment.

\section{Absence of IRS-1 Causes Increase in Bax Levels}

In addition to cytochrome $\mathrm{C}$, we also investigated another member of the Bcl-2 family, Bax. Western blot analyses showed significant increases in Bax protein levels in high glucose samples compared to normal glucose samples (Figure 2-5) (\#p $<0.05$ vs. $5 \mathrm{mM}$ Glucose). Stimulation with salmeterol showed that salmeterol could only reduce Bax when IRS-1 was active (Figure 2-5) ( $\$ \mathrm{p}<0.05$ vs. salmeterol alone). These findings were in agreement with previous studies that suggested increased Bax levels in a hyperglycemic environment; ${ }^{50,83}$ however, these are the first to our knowledge to link beta-adrenergic receptors and IRS-1 to Bax levels in retinal Müller cells.

The IRS complex proteins are responsible for mediating the downstream actions of the insulin receptor. The IRS complex consists of IRS 1-4, with each substrate playing a significant role in the body; however animal studies have shown that a vast majority of insulin actions signal through IRS-1 and IRS-2. ${ }^{87}$ The amino acid sequence of IRS-possesses a unique signaling mechanism of tyrosine phosphorylation sites and serine phosphorylation sites ${ }^{37,38,70,75-78,88,89}$ to regulate cellular actions. Phosphorylation of various tyrosine sites, $\left(\mathrm{Y}^{99}, \mathrm{Y}^{1150}, \mathrm{Y}^{1151}\right)$ and several serine sites $\left(\operatorname{Ser}^{265}, \mathrm{Ser}^{302}, \mathrm{Ser}^{325}\right.$, Ser ${ }^{358)}$ increase downstream signaling mediated by IRS-1. In contrast, other serine residues (such as $\mathrm{Ser}^{307}$, Ser ${ }^{636}$, Ser ${ }^{639}$ ) have been shown to inhibit signaling downstream of IRS-1, suggesting that IRS-1 phosphorylation may be a key regulator for activation or inhibition of a multitude of signaling cascades.

Based upon literature in other cell types, with the onset of diabetes, TNF $\alpha$ preferentially phosphorylates Ser $^{307}$ on IRS-1. ${ }^{31,38,90}$ Phosphorylation of IRS-1 ${ }^{\text {Ser307 }}$ can play an inhibitory role in insulin/IGF-1 receptor signal transduction, potentially leading to the increased apoptosis noted in the diabetic retina. ${ }^{31,38,90}$ Present findings in Müller cells (Figure 2-6) confirm work in adipose tissue cells, which suggested that TNF $\alpha$ negatively regulates insulin receptor signaling by phosphorylating Ser $^{307}$ on IRS-1 to inhibit insulin action. $^{31,38}$ In these studies, we began using a selective beta-2-adrenergic receptor agonist, salmeterol, to selectively stimulate the beta-2-adrenergic receptor, since we have 


\section{Cytochrome C}

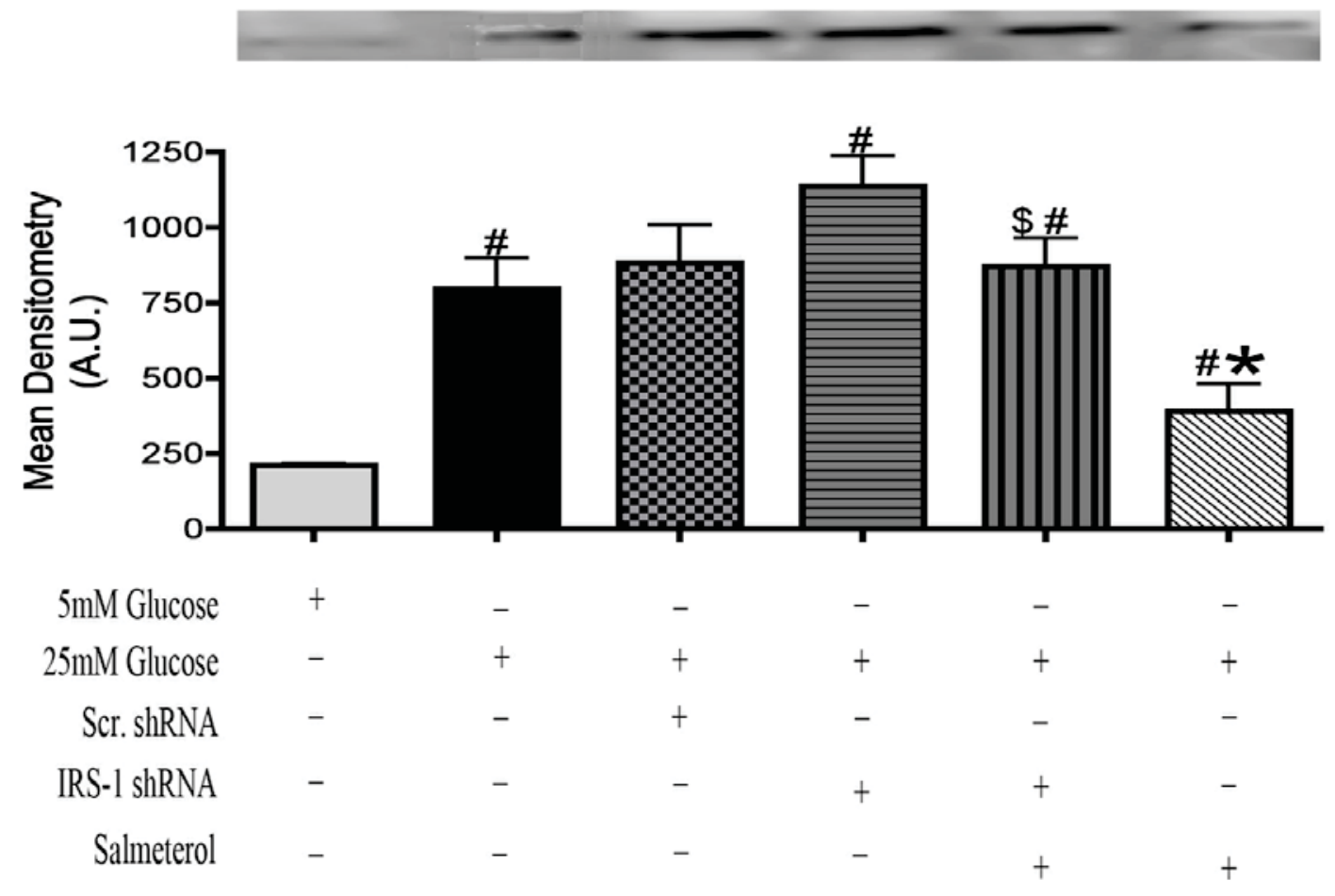

Figure 2-4. Levels of cytochrome $C$ increased in IRS-1 knockdown

Mean densitometry displayed a significant increase in cytochrome c levels cultured in $25 \mathrm{mM}$ Glucose vs. $5 \mathrm{mM}$ Glucose samples. Knockdown of IRS-1 protein significantly increased cytochrome C levels vs. $5 \mathrm{mM} \& 25 \mathrm{mM}$ Glucose samples. Western blot data showing that treatment with salmeterol significantly decreased levels of pro-apoptotic cytochrome $\mathrm{C}\left({ }^{*} \mathrm{p}<0.05\right.$ vs. NT, $\$ \mathrm{p}<0.05$ vs. salmeterol $n=4$ for Western blot.) 


\section{Bax}

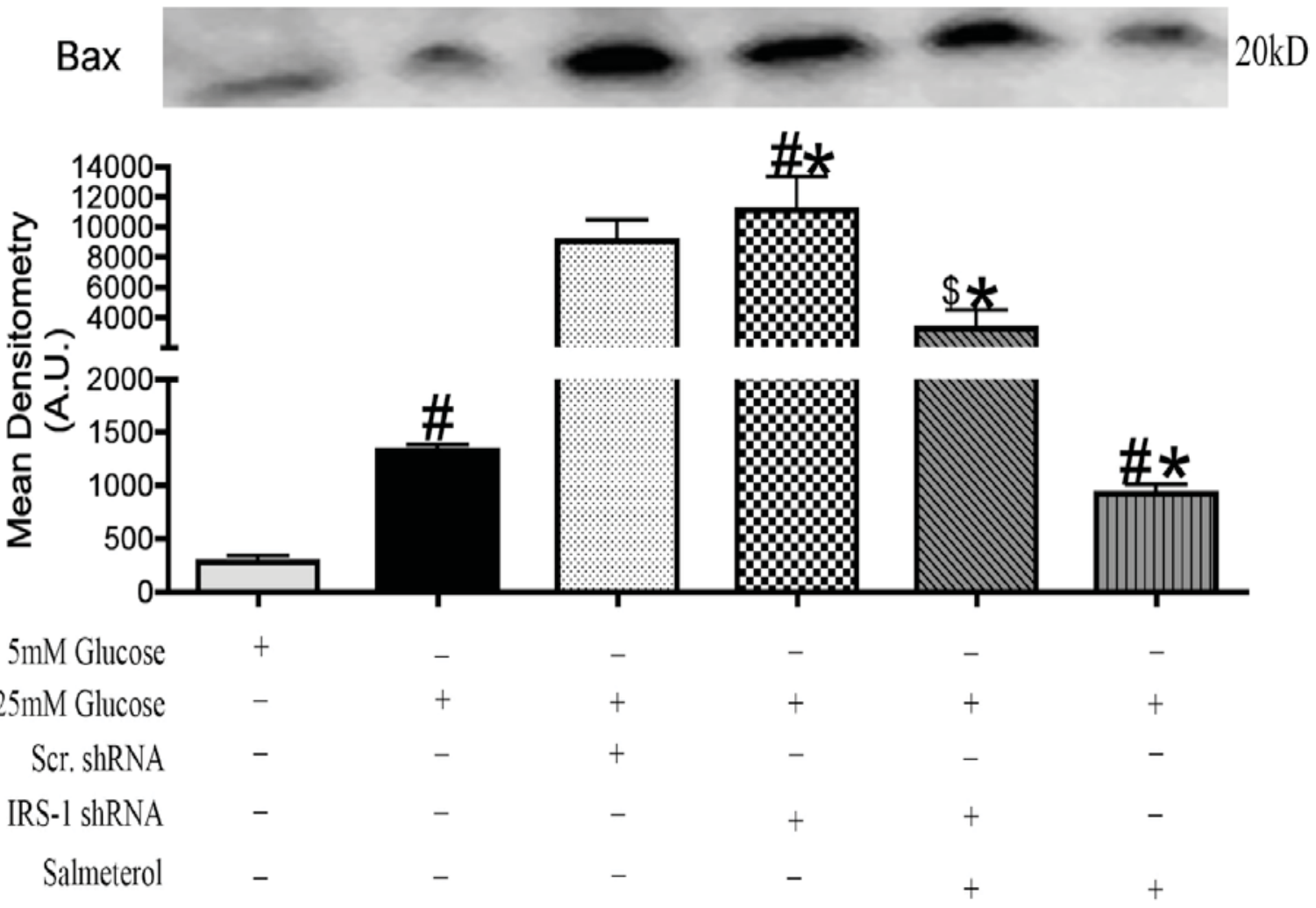

Figure 2-5. Bax protein levels increased in IRS-1 knockdown

Protein levels of Bax were significantly increased 25mM Glucose vs. 5mM Glucose samples. Transfection of IRS-1 shRNA in Müller cells significantly increased levels of pro-apoptotic Bax. 10 $\mu \mathrm{M}$ salmeterol significantly decreased Bax levels activity after 6 hours of treatment. Significance was determined by Mann-Whitney test $\left({ }^{*} \mathrm{p}<0.05\right.$ vs. $25 \mathrm{mM}$ Glucose, $\$ \mathrm{p}<0.05$ vs. salmeterol $\mathrm{n}=4$, $\# \mathrm{p}<0.05$ vs. $5 \mathrm{mM}$ Glucose, $n=4$ for Western blot). 


\section{Bcl-xL}
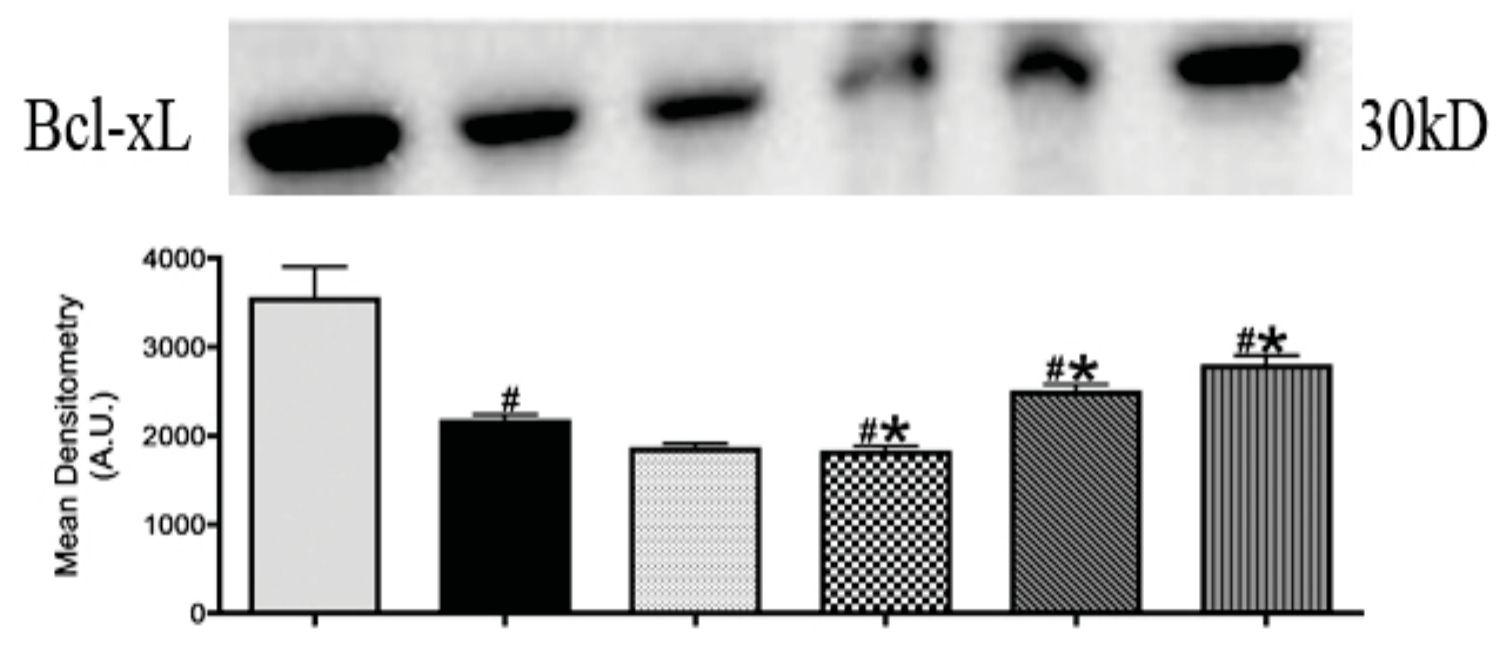

$\begin{array}{rcccccc}\text { 5mM Glucose } & + & - & - & - & - & - \\ 25 \mathrm{mM} \text { Glucose } & - & + & + & + & + & + \\ \text { Scr. shRNA } & - & - & + & - & - & - \\ \text { IRS-1 shRNA } & - & - & - & + & + & - \\ \text { Salmeterol } & - & - & - & - & + & +\end{array}$

Figure 2-6. Anti-apoptotic Bcl-xL levels decreased in IRS-1 knockdown

Western blot analysis showing significantly decreased levels of Bcl-xL vs. 5mM Glucose and $25 \mathrm{mM}$ Glucose. Salmeterol treatment significantly increased levels of Bcl-xL toward basal levels. Significance was determined by one-tailed, non-parametric Mann-Whitney tests on Western blot data. ( ${ }^{*} \mathrm{P}<0.05$ vs. $25 \mathrm{mM}$ Glucose, $\$ \mathrm{p}<0.05$ vs. salmeterol $\mathrm{n}=4, \# \mathrm{p}<0.05$ vs. $5 \mathrm{mM}$ Glucose, $n=4$.) 
recently found that this receptor is active in retinal Müller cells. Our findings in this study with salmeterol demonstrate that beta-2-adrenergic receptor stimulation may inhibit cytokine release in retinal Müller cells cultured in a hyperglycemic environment, resulting in reduced IRS-1 ${ }^{\text {Ser307 }}$ phosphorylation, leading to decreased apoptosis.

Additionally, we investigated whether beta-adrenergic receptors regulate apoptosis of retinal Müller cells through IRS-1 signaling. Since we know that beta-adrenergic receptors can decrease cell death in a high glucose environment, ${ }^{91}$ we sought to determine whether modulation of IRS-1 was involved. Knockdown of IRS-1 showed a significant increase in cell death compared to samples in $5 \mathrm{mM}$ glucose, but stimulation of the beta-2-adrenergic receptor with salmeterol prevented cell death through IRS-1 in a hyperglycemic environment on retinal Müller cells.

\section{Discussion}

Several factors can influence the increase in apoptosis. An imbalance in the expression of anti-apoptotic vs. pro-apoptotic members of the Bcl-2 family within the mitochondria of retinal Müller cells is one possibility. Retinal Müller cell samples cultured in a $25 \mathrm{mM}$ glucose environment showed a significant increase in cytochrome $\mathrm{C}$ and Bax levels compared to samples cultured in $5 \mathrm{mM}$ glucose. We found that activation of cytochrome $\mathrm{C}$ and Bax in a hyperglycemic environment was reduced following treatment with salmeterol. Increases in cytochrome $\mathrm{C}$ and Bax were also demonstrated with IRS-1 shRNA + salmeterol, indicative of increased cell death following knockdown of IRS-1 versus cells treated with salmeterol alone. Our results suggest that beta-adrenergic receptors play a specific role in the regulation of key apoptotic markers through alterations in IRS-1 levels. In support of this finding, we also found that high glucose decreased anti-apoptotic, Bcl-xL but treatment with salmeterol significantly increased Bcl-xL in a hyperglycemic environment. Decreased Bcl-xL levels were also observed in IRS-1 shRNA + salmeterol treatments, suggesting that the anti-apoptotic effects of Bcl-xL restored with treatment of salmeterol required IRS-1 for activation.

To our knowledge, we identify for the first time that salmeterol, a beta-2-adrenergic receptor agonist, can reduce cell death activity in retinal Müller cells using IRS-1 signaling. However, our results are not in agreement with previous results

that suggest that IRS-2 is the key mediator of cell death in whole retinal samples. ${ }^{37,39}$ The discrepancies in our findings compared to previous studies likely stem from the fact that we concentrated solely on in vitro studies using retinal Müller cells. Previous studies have dealt with in vivo and ex vivo studies using whole retinal samples, which contain a variety of retinal cell types. In other work from our lab, ${ }^{91}$ we have found differences in insulin receptor substrate signaling in retinal endothelial cells, which tend to signal through an IGF-1 receptor/IRS-2-dependent mechanism. ${ }^{91}$ Thus, it appears that different cell types in the retina may use different IRS complexes for cellular signaling, which expands the signaling possibilities of retinal cells. While we recognize that IRS-1 is a key component of insulin signaling, we chose to focus our investigations on beta-adrenergic receptor regulation of apoptosis of retinal Müller cells through the 
actions of IRS-1 rather than insulin receptor or IGF-1 receptor actions. Future studies may be directed at beta-adrenergic receptor actions and cross talk with insulin signaling.

In summary, these studies demonstrate that retinal Müller cells cultured in an hyperglycemic environment activate a number of mechanisms leading to increased cell death; 1) the initial mechanism involving increases in phosphorylation of IRS- $1^{\text {Ser } 307}$-mediated by increased TNF $\alpha$ levels in the diabetic retina ${ }^{54} ; 2$ ) the second mechanism involving significant increases in apoptotic markers Bax and cytochrome $\mathrm{C}$, coupled with a significant decrease in anti-apoptotic Bcl-xL. Both mechanisms of cell death were significantly inhibited following treatment with a beta-2-adrenergic receptor agonist, salmeterol. Taken together, these results suggest that beta-adrenergic receptors require active IRS-1 to prevent cell death in retinal Müller cells. 


\section{CHAPTER 3. ROLE OF $\beta$-ADRENERGIC RECEPTOR'S REGULATION OF TNF- $\alpha$ AND INSULIN SIGNALING IN RETINAL MÜLLER CELLS*}

\section{Introduction}

Diabetes is a growing epidemic caused by excess glucose levels and the body's inability to produce or regulate insulin. ${ }^{93}$ While there is a significant amount of research ongoing on the regulation of insulin, very little of that research has focused on insulin regulation in the eye as it may relate to diabetic retinopathy. Diabetic retinopathy is the leading cause of vision loss in people of working age in North America. ${ }^{49,93}$ It is unknown whether altered insulin actions in the retina are involved in the pathogenesis of diabetic retinopathy. ${ }^{49,93}$ The normal mechanism of insulin action is mediated by binding the insulin receptor, which is located on the cell membrane. ${ }^{38}$ This receptor is made up of two alpha subunits and two beta subunits, which are connected by disulfide bonds. ${ }^{37,39}$ The actions of insulin are initiated when the receptor is bound on the alpha subunits, causing phosphorylation of tyrosine kinases of the beta subunits and inducing a conformational change. ${ }^{37,39}$

Previous work on insulin signaling in the retina has suggested that phosphorylation of the insulin receptor can activate insulin receptor substrate complexes (IRS1-4) and lead to phosphorylation of Akt. ${ }^{39}$ Further research efforts in adipose and retinal tissues have suggested that phosphorylation on specific serine sites (Ser 307) on IRS-1 reduces tyrosine phosphorylation activity of insulin receptor ${ }^{73}$ (Chapter 1). The cytokine TNF- $\alpha$ has been suggested to regulate IRS-1 through the serine 307 site. TNF- $\alpha$ induced inhibition of IRS-1 signaling would decrease Akt phosphorylation to potentially induce apoptosis.

Our lab has previously shown that Müller cells have increased TNF- $\alpha$ levels in a hyperglycemic environment, which was reduced following $\beta$-adrenergic receptor stimulation. ${ }^{29}$ Since $\beta$-adrenergic receptors can decrease TNF- $\alpha$ and TNF- $\alpha$ negatively regulates insulin receptor signaling to induce apoptosis, our studies sought to determine the mechanisms by which $\beta$-adrenergic receptors modulate insulin receptor signaling and apoptosis in retinal Müller cells. Previous investigations have concentrated on insulin signaling in the retina, ${ }^{37,39,40,45,52,94,95}$ with less work focusing on the role of $\beta$-adrenergic receptor regulation of insulin signaling in the retina. Our recent work with IRS-1 (Chapter 2) suggests that $\beta$-adrenergic receptors on retinal Müller cells may play a role in insulin signaling, as it relates to diabetic retinopathy. Since $\beta$-adrenergic receptors have been reported to interact with insulin receptor signaling in other targets, it suggests that $\beta$-adrenergic receptor regulation of insulin signaling may be involved in the anti-apoptotic actions observed following $\beta$-adrenergic receptor agonist stimulation. ${ }^{96}$

\footnotetext{
* Source: Reprinted with permission. Walker RJ, Anderson NM, Jiang Y, Bahouth S, Steinle JJ. Role of $\beta$-adrenergic receptors regulation of TNF- $\alpha$ and insulin signaling in retinal Müller cells. Investigative Ophthalmology \& Visual Science $2011 .^{92}$
} 
In this present study, we propose that treatment with a selective $\beta$-2-adrenergic receptor agonist, salmeterol, will decrease levels of TNF- $\alpha$, leading to increased insulin receptor signaling. Additional studies will use TNF- $\alpha$ shRNA to further characterize the function of TNF- $\alpha$ in the regulation of insulin receptor signaling. These findings will allow us to further understand the regulation of insulin signaling in the retina, specifically on retinal Müller cells.

\section{Results}

\section{Stimulation of Beta-Adrenergic Receptors Increases Insulin Receptor Signaling}

We examined the phosphorylation activity of the insulin receptor using rMC-1 cells in normoglycemic and hyperglycemic environments. Previous work has shown loss of retinal insulin receptor activity in diabetes. ${ }^{39}$ Our results indicate that isoproterenol treatment, a non-selective $\beta$-adrenergic receptor agonist, significantly increased phosphorylation of the insulin receptor $\left({ }^{*} \mathrm{P}<0.01 \mathrm{vs}\right.$. not treated) after 1 hour treatment (Figure 3-1A). Typically, phosphorylation of the insulin receptor should increase phosphorylation of Akt. Following treatment of rMC-1 cells with $10 \mu \mathrm{M}$ isoproterenol, Akt phosphorylation levels were significantly increased $\left({ }^{*} \mathrm{p}<0.01 \mathrm{vs}\right.$. not treated) after one hour of treatment (Figure 3-1B). These results indicate that, insulin receptor signaling is regulated by $\beta$-adrenergic receptors.

\section{Stimulation of Beta-Adrenergic Receptors Decreases Cleaved Caspase 3}

Increased phosphorylation activity of Akt contributes to significant decreases in levels of the pro-apoptotic proteins, cytochrome c, caspase 9, and caspase 3. In Figure 3-2, we show treatment with $10 \mu \mathrm{M}$ isoproterenol for 24 hours significantly decreases cleaved caspase 3 levels (Figure 3-2) $\left({ }^{*} p<0.05\right.$ vs. not treated).

\section{Blocking of Beta-Adrenergic Receptor by Selective Inhibitors}

Previously, we have identified that Müller cells express $\beta-1-$ and $\beta-2$ adrenergic receptors. ${ }^{29}$ In these studies, we chose to use a pharmacological approach to determine the dominant receptor present on Müller cells using 300nM of CGP 20712A $(\beta$-1-adrenergic receptor antagonist) and 50nM of ICI 118.551 ( $\beta$-2-adrenergic receptor antagonist $)^{97}$ with isoproterenol as a stimulus to the receptor not being inhibited. Treatment with $\beta$-1-adrenergic receptor antagonist followed by stimulation of isoproterenol for $1,6,12,24$ hours showed significant decreases in cleaved caspase 3 (Figure 3-3A) $(\# p<0.05$ vs. not treated, $* p<0.01$ vs. ICI samples). Inhibition of $\beta$-2-adrenergic receptors by antagonist with stimulation of isoproterenol resulted in significant increases $(\# \mathrm{p}<0.01$ vs. not treated) in cleaved caspase 3 activity 
A.

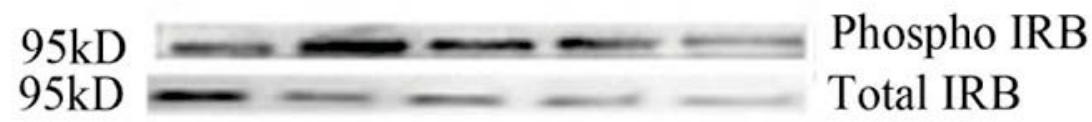

PIRB/Insulin Receptor

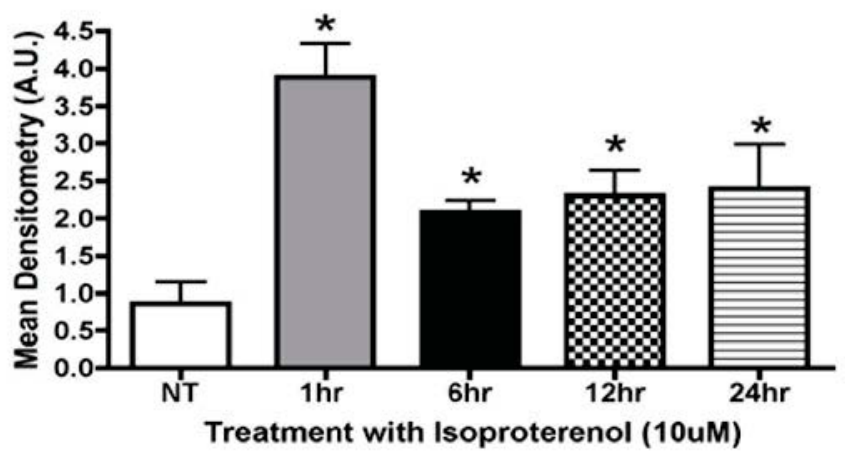

B.

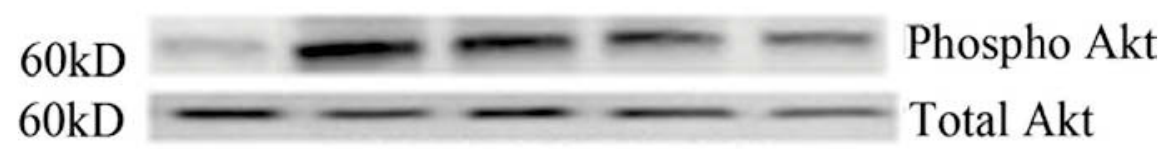

PAKTIAKT

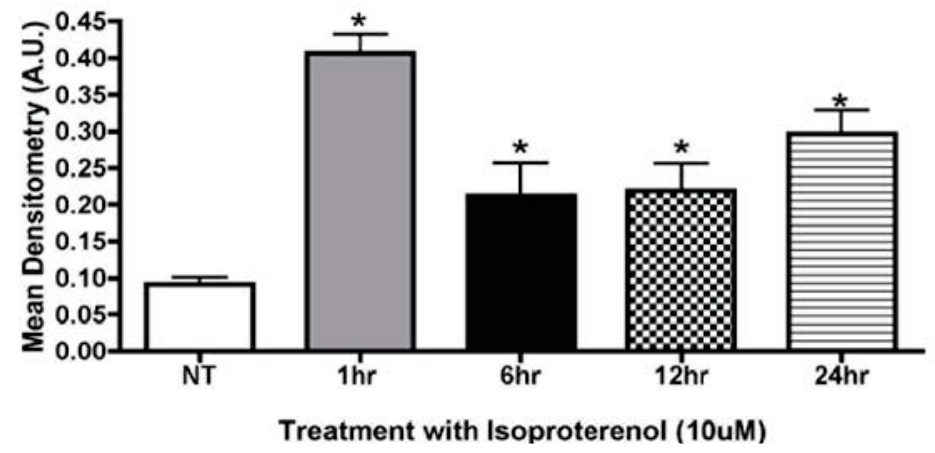

Figure 3-1. Treatment with isoproterenol restores phosphorylation of IRB and Akt

(A) Mean densitometry of protein levels of phosphorylation of insulin receptor are significantly increased in Müller cells following treatment with $\beta$-adrenergic receptor agonist, isoproterenol. (B) Mean densitometry of ratio for Akt shows that protein levels of Akt were significantly increased in Müller cells cultured in high glucose $(25 \mathrm{mM}$ glucose) medium following treatment with $10 \mu \mathrm{M}$ isoproterenol. Significance was determined by one-tailed, non-parametric T-tests on western blot data (A)* $\mathrm{p}<0.05$ vs. not treated, $n=4,(B) * p<0.05$ vs. not treated, $n=4$. 


\section{Caspase 3 in rMC-1}

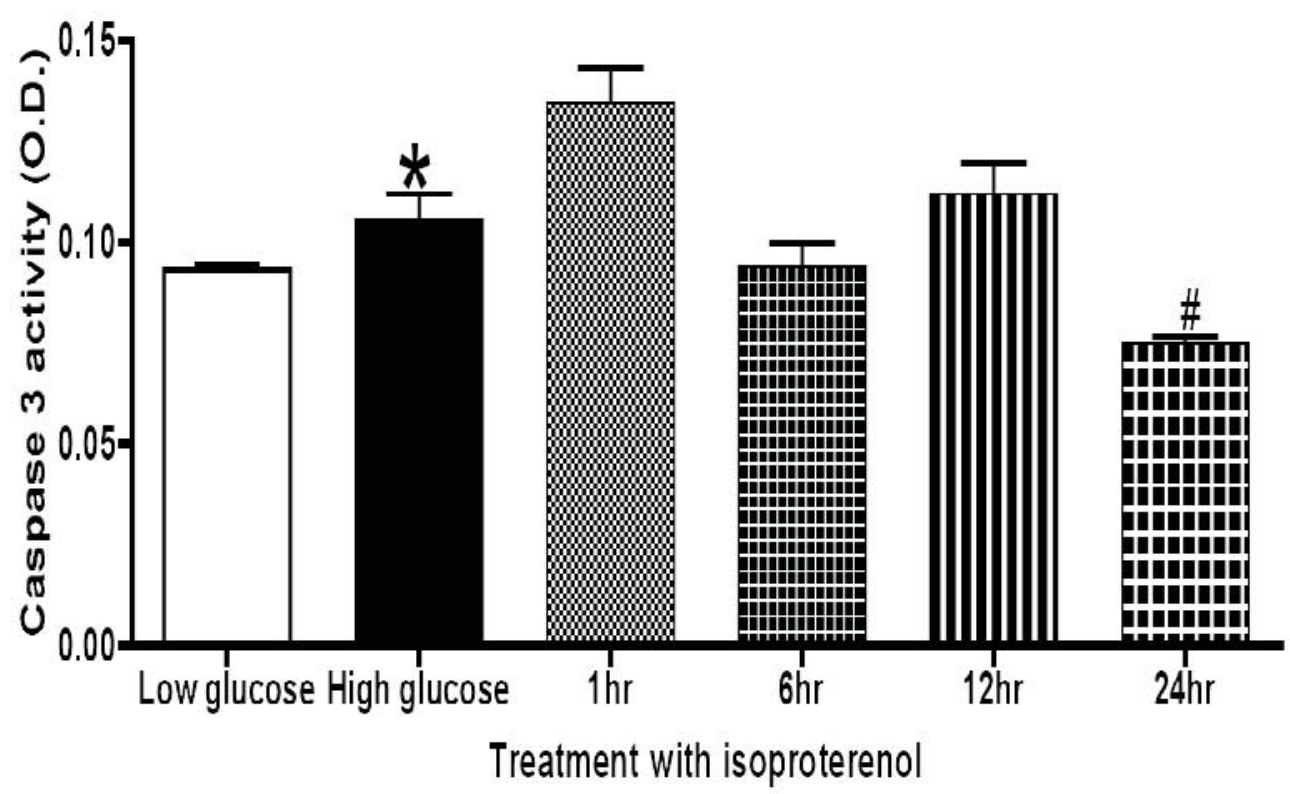

Figure 3-2. Levels of cleaved caspase 3 reduced following treatment

ELISA of cleaved caspase 3 in rat Müller cells showed significantly increased apoptosis in high glucose as compared to low glucose. Treatment with isoproterenol significantly decreased caspase 3 activity after 24 hours of treatment in Müller cells. Significance was determined by Mann-Whitney test $\left({ }^{*} \mathrm{p}<0.05\right.$ vs. Low Glucose, $\# \mathrm{p}<0.05$ vs. High Glucose, $n=5$ ). 


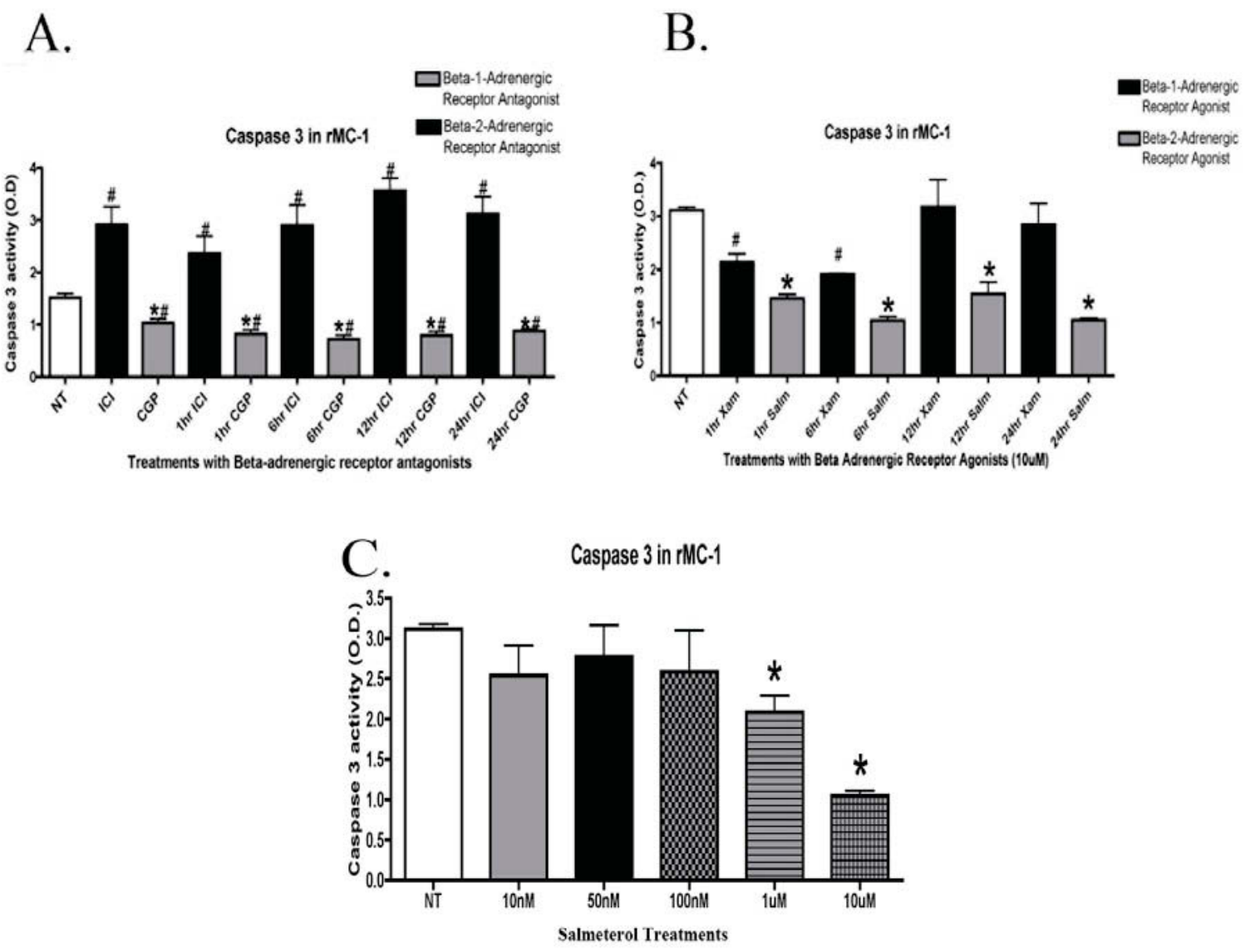

Figure 3-3. Levels of cleaved caspase 3 in retinal Müller cells

ELISA analysis showed a significant increase in samples treated with ICI 118.551 $(\beta$-1-adrenergic receptor antagonist) compared to not treated samples. Caspase 3 levels were significantly decreased in samples treated with CGP 20712A ( $\beta$-2-adrenergic receptor antagonist) vs. not treated ( ${ }^{*} \mathrm{p}<0.05$ vs. nt, \#ICI vs. CGP $n=5$ for ELISA assay). (B) Rat Müller cells treated with $\beta$-1-adrenergic receptor agonist, xamoterol (XAM) and $\beta$-2-adrenergic receptor agonist, salmeterol (SAL) for 1-24 hours. Treatment with salmeterol significantly decreased caspase 3 levels, after 1 hour of treatment in Müller cells, while treatment with xamoterol showed little effect after the 6hour treatment point. Statistical significance was determined Mann-Whitney test $\left({ }^{*} p<0.05\right.$ vs. not treated, \#Xam vs. Sal $n=5$ for ELISA assay). (C) Dose response of selective $\beta$-2-adrenergic receptor agonist, salmeterol. Treatment with $1 \mu \mathrm{M}$ and $10 \mu \mathrm{M}$ significantly decreased caspase 3 activity after 6 hours of treatment in Müller cells. Significance was determined by Mann-Whitney test $(* \mathrm{p}<0.05$ vs. nt, $n=5)$. 
(Figure 3-3A). These results suggest that $\beta$-2-adrenergic receptors regulate apoptotic signaling in retinal Müller cells.

To further confirm the findings using $\beta$-adrenergic receptor antagonists, we also treated Müller cells with $\beta$-adrenergic receptor agonists. Treatment with a selective $\beta$-1-adrenergic receptor agonist, xamoterol, significantly decreased caspase 3 levels after 1 and 6 hours of treatment (Figure 3-3B) $\left({ }^{*} p<0.05\right.$ vs. not treated). Treatment with a $\beta$-2-adrenergic receptor agonist, salmeterol, significantly decreased cleaved caspase 3 levels at all timepoints (Figure 3-3B) $(* p<0.05$ vs. not treated), which demonstrates that the $\beta$-2-adrenergic receptor is indeed key $\beta$-adrenergic receptor subtype for apoptotic signalling in retinal Müller cells. Following treatment of cells with $10 \mathrm{nM}, 50 \mathrm{nM}$, $100 \mathrm{nM}, 1 \mu \mathrm{M}$, and $10 \mu \mathrm{M}$ concentrations of salmeterol, we found that the $10 \mu \mathrm{M}$ concentration produced the greatest decrease in cleaved caspase 3 levels compared to the other concentrations tested (Figure 3-3C).

\section{Salmeterol Significantly Reduces TNF- $\alpha$, while Increasing Insulin Receptor and Akt Phosphorylation}

ELISA analysis reveals that Müller cells treated with TNF- $\alpha$ alone displayed significant increases levels of TNF- $\alpha$ in a hyperglycemic environment (Figure 3-4A) $(* p<0.05$ vs. not treated). Following treatment with salmeterol, levels of TNF- $\alpha$ were significantly decreased (Figure 3-4A) $\left({ }^{*} p<0.05\right.$ vs. not treated, $\# p<0.05$ vs. TNF- $\alpha$ alone).

Further efforts to determine whether $\beta$-2-adrenergic receptor stimulation alone could increase insulin receptor signaling demonstrated a significant increase of phosphorylation following treatment with $10 \mu \mathrm{M}$ salmeterol (Figure 3-4B). Over expression of TNF- $\alpha$ in Müller cells resulted in a significant decrease of tyrosine phosphorylation on insulin receptor in high glucose conditions (Figure 3-4B) $(* \mathrm{p}<0.05$ vs. not treated, $\# p<0.05$ vs. TNF- $\alpha$ alone). These findings suggest that $\beta$-adrenergic receptor regulation of insulin receptor phosphorylation occurs predominantly through the $\beta$-2-adrenergic receptor subtype. Similar to the results on insulin receptor regulation, selective $\beta$-2-adrenergic receptors agonist treatment increases Akt phosphorylation on serine 473 (Figure 3-4C) $\left({ }^{*} p<0.05\right.$ vs. not treated, $\# p<0.05$ vs. TNF- $\alpha$ alone). A significant decrease in phosphorylation of Akt was noted with TNF- $\alpha$ only treatment. Taken together, these data suggest that $\beta$-2-adrenergic receptors may regulate insulin receptor and Akt actions.

\section{Silencing of TNF- $\alpha$ Plays Critical Role in Phosphorylation of Akt and IRS-1 ${ }^{\text {Ser } 307}$}

Our present data suggests that TNF- $\alpha$ has a modulatory role in insulin receptor signaling, specifically downstream of the insulin receptor with actions on proteins such as Akt and IRS-1 ${ }^{\text {Ser } 307}$. After verification of successful knockdown with TNF- $\alpha$ shRNA (Figure 3-5A), we found a significant decrease in Akt in rMC-1 in cells cultured in high 

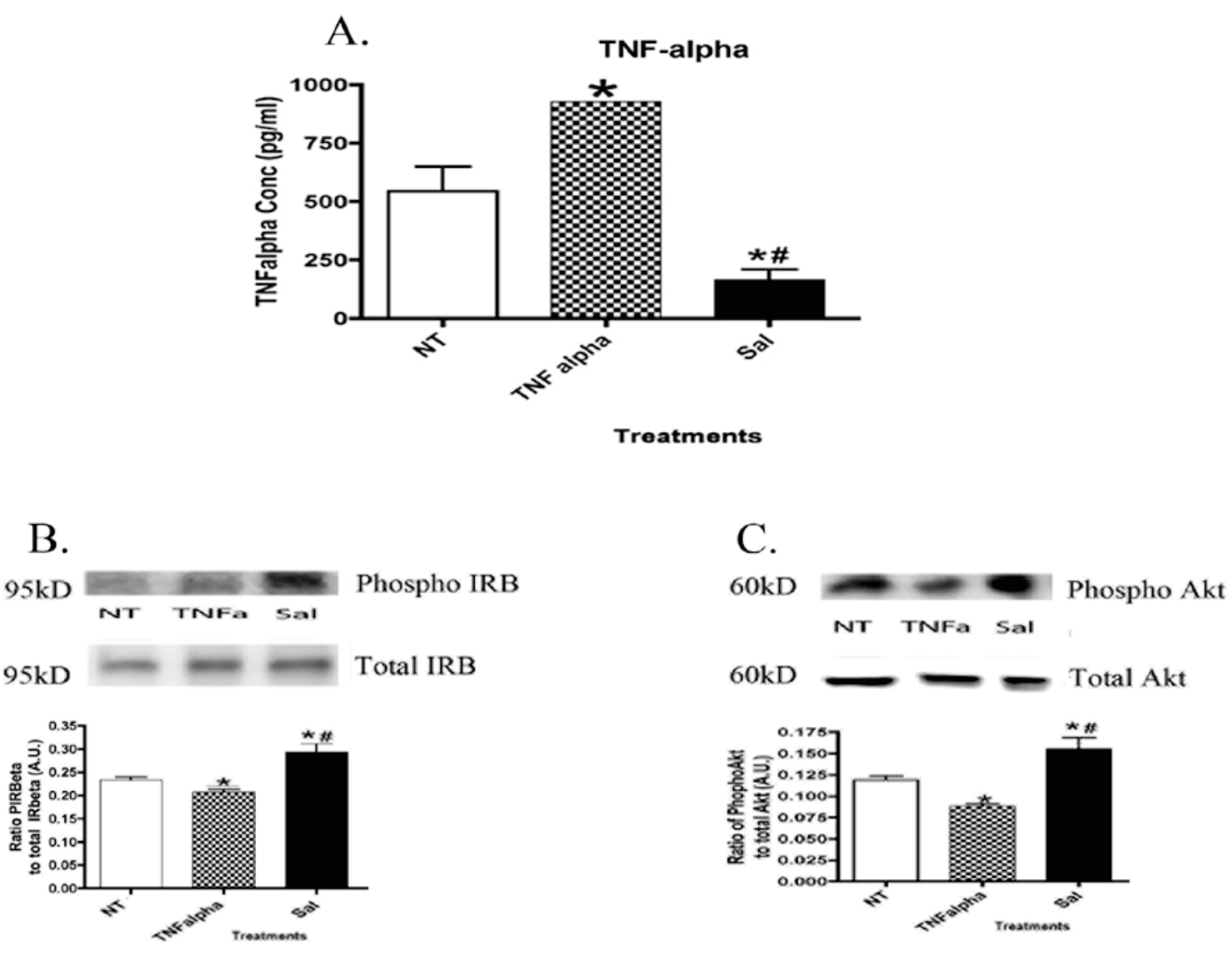

Figure 3-4. Stimulation of TNF- $\alpha$ in retinal Müller cells

(A) ELISA of Tumor Necrosis Factor alpha (TNF- $\alpha$ ) displaying significant increases in TNF- $\alpha$ alone treatment levels. Treatment with salmeterol significantly decreases levels of TNF- $\alpha$. Significance of statistics was determined by Mann-Whitney test $\left({ }^{*} \mathrm{p}<0.05\right.$ vs. not treated, $\# \mathrm{p}<0.05 \mathrm{vs}$. TNF- $\alpha$ alone, $n=5$ ). (B) Mean densitometry of protein phosphorylation ratios for insulin receptor beta was significantly decreased in TNF- $\alpha$ treated cells, but treatment with $10 \mu \mathrm{M}$ salmeterol significantly increases phosphorylation activity of insulin receptor in Müller cells cultured in high glucose. (C) Western blot analysis showing a significant increase in TNF- $\alpha$ alone treated cells. Treatment with salmeterol significantly increased phosphorylation activity of Akt. Statistical significance was analyzed using a non-parametric, one tailed T-test for Western blots $\left({ }^{*} \mathrm{p}<0.05 \mathrm{vs}\right.$. not treated, $\# \mathrm{p}<0.05$ vs. TNF- $\alpha$ alone, $\mathrm{n}=5$ ). 

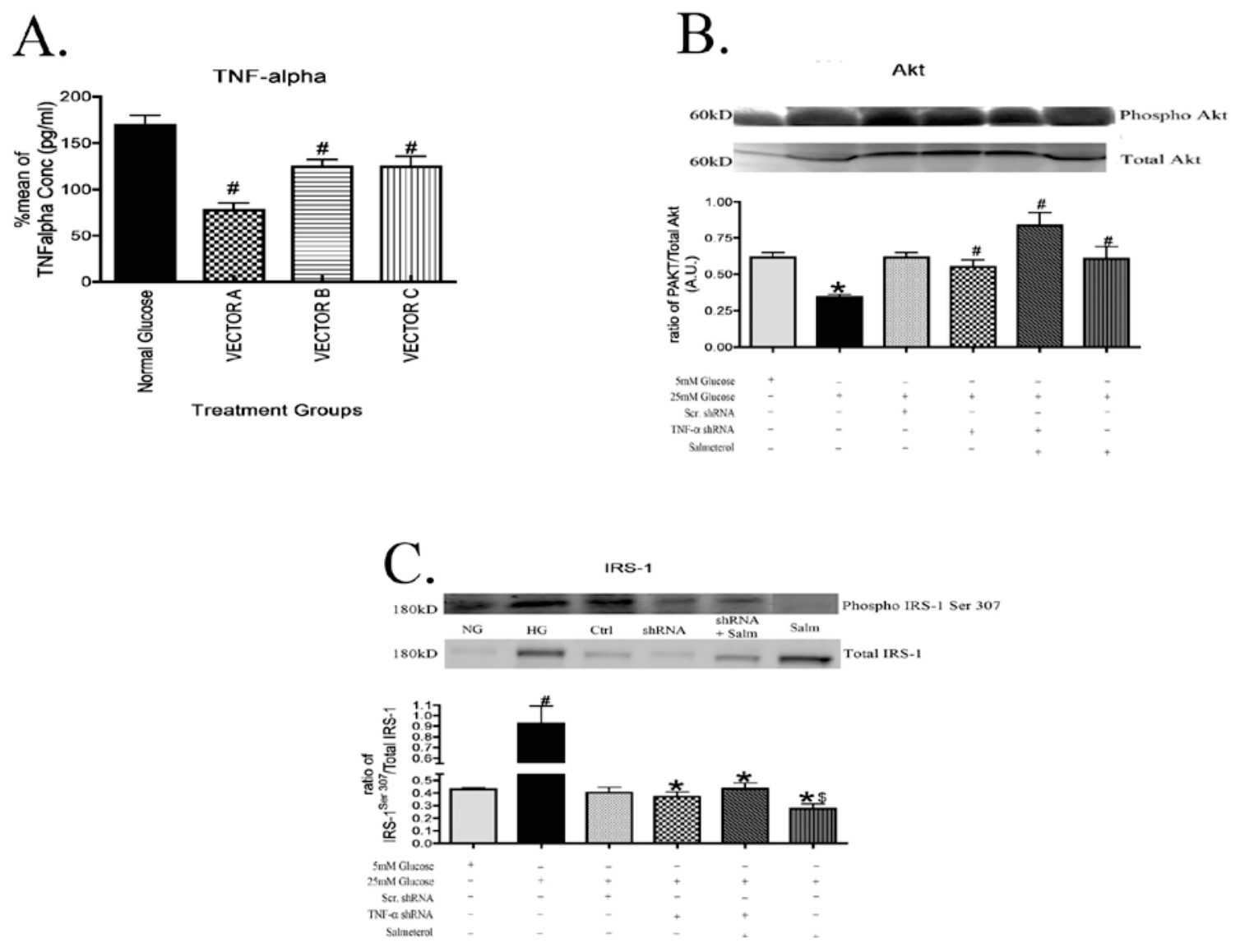

Figure 3-5. Knockdown of TNF- $\alpha$

(A) ELISA of Tumor Necrosis Factor-alpha (TNF- $\alpha$ ) showing significant decreases in various TNF- $\alpha$ shRNA vectors. Significance of statistics was determined by MannWhitney test $\left({ }^{*} \mathrm{p}<0.05\right.$ vs. not treated, $\# \mathrm{p}<0.05$ vs. TNF- $\alpha$ alone, $\left.n=5\right)$. (B) Akt phosphorylation activity was significantly increased following treatment with shRNA alone, shRNA + salmeterol, and salmeterol alone samples. (C) Western blot analysis of phosphorylation of IRS-1 ${ }^{\text {Ser307 }}$ showed a significant decrease in shRNA alone and shRNA + salmeterol treated cells compared to high glucose samples. Treatment with salmeterol also significantly decreased phosphorylation levels of IRS-1 ${ }^{\text {Ser307 }}$ in Müller cells. Significance was determined by one-tailed, non-parametric Mann-Whitney tests on western blot data $(* \mathrm{P}<0.05$ vs. $25 \mathrm{mM}$ Glucose, $\$ \mathrm{P}<0.05$ vs. salmeterol $\mathrm{n}=4$, $\# \mathrm{p}<0.05$ vs. $5 \mathrm{mM}$ Glucose, $n=4)$. 
glucose, which was inhibited in cells treated with salmeterol (Figure 3-5B). Treatment with TNF- $\alpha$ shRNA+ salmeterol also increased Akt phosphorylation, which was expected since salmeterol alone decreases TNF- $\alpha$ actions (Figure 3-5B). Additionally, samples from scrambled control shRNA displayed results similar to that of $5 \mathrm{mM}$ glucose (Figure 3-5B).

\section{TNF- $\alpha$ Is a Mediator of Apoptosis in rMC-1 Cells}

In Müller cells, apoptosis was characterized using cell death ELISA, where the addition of TNF- $\alpha$ in a hyperglycemic environment resulted in an increase in cell death. Cellular transfections with TNF- $\alpha$ shRNA and TNF- $\alpha$ shRNA + salmeterol treatments showed significant decreases in apoptosis compared to TNF- $\alpha$ only treated samples (Figure 3-6). These results suggest that TNF- $\alpha$ plays a major role in the induction of apoptosis in Müller cells, since the inhibition of TNF- $\alpha$ significantly reduced apoptosis (Figure 3-6) $\left({ }^{*} \mathrm{P}<0.05\right.$ vs. $5 \mathrm{mM}$ glucose, $\# \mathrm{P}<0.05$ vs. $25 \mathrm{mM}$ glucose, and $\$ \mathrm{P}<0.05$ vs. TNF- $\alpha$ alone).

\section{Discussion}

The insulin receptor-insulin receptor substrate (IRS)-Akt pathway is known to be responsible for mediating numerous insulin actions at the cellular level, such as inhibition of apoptosis, maintenance of glucose levels, and synthesis of proteins. ${ }^{37,39}$ Signaling through the first steps of this pathway is highly complex and can produce $>1,000$ possible signal pathway variations. ${ }^{78}$ Insulin receptor signaling is initiated by the phosphorylation of beta subunits on specific tyrosine sites, which signals further downstream to a complex of insulin receptor substrates (IRS 1-4) that also become phosphorylated. ${ }^{37,39,73,74}$ Insulin receptor substrates are docking proteins that are responsible for eliciting insulin actions throughout the body. ${ }^{73}$ One protein that can lie downstream of the IRS complex is the anti-apoptotic factor, Akt. Phosphorylation of Akt following insulin stimulation has been suggested to inhibit the caspases, specifically caspases 3 and 9 , which results in reduced apoptosis.

These findings demonstrate that insulin receptor phosphorylation is reduced in rat Müller cells cultured in a hyperglycemic environment compared to untreated samples, which agrees with previous findings. ${ }^{37,39,95}$ Furthermore, these studies show that stimulation of $\beta$-adrenergic receptors with isoproterenol significantly increases phosphorylation of Tyr1150/1151 on insulin receptor. ${ }^{37}$ In addition to increased phosphorylation of the insulin receptor, treatment with isoproterenol also significantly increased levels of Akt phosphorylation, leading to decreased cleavage of caspase 3 .

Further studies determined that $\beta$-2-adrenergic receptors are the dominant receptors present on Müller cells for the regulation of insulin receptor signaling. Stimulation of $\beta$-2-adrenergic receptors with salmeterol, a specific $\beta$-2-adrenergic receptor agonist, showed significant increases in tyrosine phosphorylation of the insulin 
Cell Death

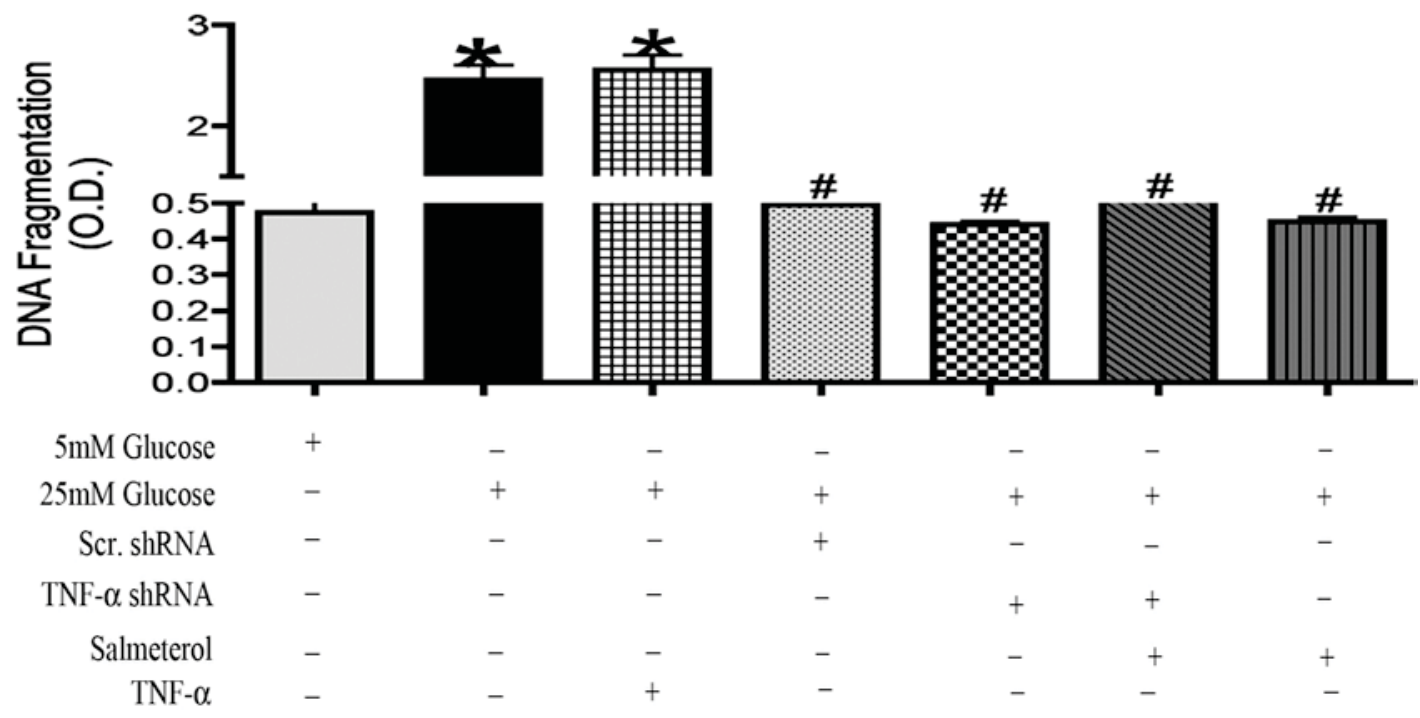

Figure 3-6. Knockdown of TNF- $\alpha$ reduces cell death

Analysis of apoptosis shows an increase in apoptosis with treatment of TNF- $\alpha$, but following transfection with TNF- $\alpha$ shRNA, levels of cell death were significantly decreased and further decreased in TNF- $\alpha$ shRNA+ salmeterol and salmeterol alone treatment. ( $* \mathrm{P}<0.05$ vs. $5 \mathrm{mM}$ glucose, $\# \mathrm{P}<0.05$ vs. $25 \mathrm{mM}$ glucose, $\mathrm{n}=5$ ). 
receptor, as well as increased phosphorylation of anti-apoptotic factor, Akt. The reduction of cell death is likely through an Akt-mediated pathway, since inhibitors to phosphatidylinositol-3-kinase also inhibited the actions of insulin. ${ }^{37}$ The results from the retinal explants agree well with our findings in retinal Müller cells.

While insulin signaling has been well studied throughout various tissues in the body, less work has focused on the regulation of insulin signaling in the retina, specifically the relationship of inflammation and insulin receptor signaling. One cell type in the retina that may be susceptible to changes in this proposed relationship is the Müller cell. Müller cells serve as structural support cells for the retina, and span the entire thickness of the retina. ${ }^{59}$ Since Müller cells become activated and express increased glial fibrillary acidic protein levels in diabetes, ${ }^{59}$ this suggests that the cells are nonhomeostatic, which will alter their regulation of inflammatory markers, glucose transport, oxidative stress, growth factors, and finally cell survival. ${ }^{98,99}$

Previous studies from our lab have shown that Müller cells display increased inflammatory markers (specifically TNF- $\alpha$ ) in a hyperglycemic environment, which was reduced following $\beta$-adrenergic receptor stimulation. ${ }^{29}$ TNF- $\alpha$ has been shown to play a major role in the induction of apoptosis in retinal cells, specifically during the onset of diabetic retinopathy. ${ }^{54}$ Use of the TNF- $\alpha$ inhibitor (etanercept) produced significant reductions in DNA fragmentation and activation of caspases, further demonstrating that this TNF- $\alpha$ is important in early diabetic abnormalities in the retina. ${ }^{54}$

In insulin receptor signaling, TNF- $\alpha$ can play an inhibitory role by directly phosphorylating IRS-1 at Ser 307, which produces a loss of insulin receptor signal transduction, leading to the increased apoptosis noted in the diabetic retina. ${ }^{31,38,100}$ Our findings in Müller cells confirm previous work in our lab in $\beta 1$-adrenergic receptor $\mathrm{KO}$ mice in which we found that phosphorylation of IRS-1 at Ser 307 is significantly increased in comparison to their wildtype littermates. ${ }^{100}$ These studies also found a significant decrease in Akt and significant increases in cleaved caspase 3 levels, as well as TNF- $\alpha$ levels in the $\beta 1$-adrenergic receptor knockout mice. ${ }^{100}$ Our present findings with salmeterol suggest that $\beta$-2-adrenergic receptor stimulation may inhibit cytokine release in retinal Müller cells cultured in a hyperglycemic environment, resulting in elimination of IRS- $1^{\text {Ser307 }}$ phosphorylation. This would allow the anti-apoptotic actions of insulin to be properly transduced to Akt, producing a reduction in apoptosis. To further confirm these findings for the role of TNF- $\alpha$ in retinal Müller cells, we demonstrated that reduction of TNF- $\alpha$ levels with shRNA significantly reduced the phosphorylation of serine 307 on IRS-1, leading to increased Akt activity.

These studies demonstrate that treatment with a $\beta$-adrenergic receptor agonist in vitro can restore the loss of insulin receptor activity noted in diabetic retinal Müller cells. These results match well in vivo studies with topical isoproterenol, in which isoproterenol negated deleterious changes in phosphorylation of the insulin-signaling pathway during diabetes in rats. ${ }^{101}$ While our findings confirm our hypothesis of TNF- $\alpha$ modulation in insulin receptor signaling, we also recognize that our findings could be the result of phosphatases such as PTP1B that were previously suggested by Rajala et al. 2010 which 
would decrease insulin receptor activity leading to a decrease in Akt activity. ${ }^{102,103}$ It is well know that insulin receptor mediates activation of caspase- 3 by signaling through the PI3K/Akt pathway as well as the MAPK pathway. ${ }^{102,103}$ Our future studies will focus more in detail on the relationship of the PI3K and MAPK pathways in retinal Müller cells.

Further explanation of Akt modulation of cell death presented in the current study can be explained by previous findings by Gottlob et al., 2001 in which it was suggested that Akt mediates hexokinase activity in the mitochondria of cells. ${ }^{104}$ An upregulation of hexokinase in the mitochondria was found to inhibit apoptosis. Further findings by Majewski et al. suggested that this anti-apoptotic action of hexokinase was the result of its ability to inhibit cytochrome $\mathrm{C}$ release once placed in the mitochondria. ${ }^{105}$ These previous findings are in line with our labs findings in retinal Müller cells that showed an increase in release of cytochrome $C$ following silencing of IRS-1, this loss of IRS-1 led to a decrease in Akt (Walker et al. in submission).

In conclusion, we have demonstrated that the $\beta$-2-adrenergic receptor is the dominant receptor subtype to mediate insulin actions in retinal Müller cells. Furthermore, we have shown that a selective $\beta$-2-adrenergic receptor agonist, salmeterol, can increase insulin receptor signal transduction, leading to decreased apoptosis. Salmeterol increases the actions of insulin through inhibition of TNF- $\alpha$ actions in the retinal Müller cells cultured in high glucose. In this manner, salmeterol inhibits the TNF- $\alpha$-mediated increased phosphorylation of IRS-1 ${ }^{\text {Ser307 }}$, allowing insulin actions to be transduced to Akt, thus preventing apoptosis. These results provide a potential mechanism of action for $\beta$-adrenergic receptor therapies for diabetic retinopathy. 


\section{CHAPTER 4. DUAL SIGNALING OF G PROTEIN COUPLED RECEPTORS REDUCES CELL DEATH IN RETINAL MÜLLER CELLS}

\section{Introduction}

The family known as the G protein-coupled receptors (GPCRs) is a group of proteins that use cells to adapt and react to their surrounding environments. Past research has identified more than 300 GPCRs in the human genome. ${ }^{106}$ In addition to these receptors that have been identified, there are more than 160 that remain undefined, currently referred to as orphan GPCRs due to unknown ligands. Activation of the G proteins produces cellular signaling through a variety of signaling cascades. ${ }^{107}$

The beta-adrenergic receptors are family A members of the G-coupled protein receptors that spread signals by activating and eliciting action through various signaling pathways. The beta-adrenergic receptors contain seven transmembrane helices that are a common feature among other family members of the GPCRs. ${ }^{3,108,109}$ Activation of the beta-adrenergic receptors takes place in a site within the transmembrane region, which allows ligand binding of two neurotransmitters, norepinephrine and epinephrine. ${ }^{6}$ These neurotransmitters signal through guanine nucleotide binding proteins ( $G$ proteins) to elicit various cellular actions such as phosphorylation of receptors and activation of various signaling pathways. ${ }^{110}$ The G proteins consist of three functional subunits, a large alpha subunit, a beta subunit, and a gamma subunit. The larger alpha subunit is divided into four families, $G_{s}, G_{i}, G_{q}$, and $G_{12}$, based upon sequences of amino acids, rather than functional characteristics. ${ }^{110}$

Previous knowledge of beta-adrenergic receptor ( $\beta$-AR) signaling has suggested that $\mathrm{G}$ protein signals following binding of norepinephrine or epinephrine to the $\beta$-adrenergic receptor to trigger $\mathrm{G}_{\mathrm{s}}$ protein, activating the enzyme, adenyl cyclase. ${ }^{8}$ Adenylate cyclase stimulates the second messenger cyclic AMP (cAMP) to activate kinase A (PKA) to elicit its effects on a cellular level by phosphorylating various signaling cascades. ${ }^{111}$ Recent studies in the heart have shown that stimulation of $\beta 1$ - and $\beta 2$-ARs can signal through different $\mathrm{G}$ alpha proteins. ${ }^{112} \beta 1$-AR stimulation typically activates $\mathrm{G}_{\mathrm{s}}$-cAMP- PKA pathway, ${ }^{112}$ while stimulation of $\beta 2$-ARs dually signals through a $\mathrm{G}_{\mathrm{s}} / \mathrm{G}_{\mathrm{i}}$ mechanism in cardiac myocytes. ${ }^{8,113,114}$

The retina is known to express at least three different subtypes of beta-adrenergic receptors, with $\beta 1$ - and $\beta 3$-adrenergic receptors present on retinal endothelial cells ${ }^{10}$ and $\beta 1$ - and $\beta 2$-adrenergic receptors present on retinal Müller cells. ${ }^{29}$ Although $\beta 1$ - and $\beta 2$-adrenergic receptors are both present on retinal Müller cells, we have shown in recent studies that the $\beta 2$-adrenergic receptor subtype is the dominant subtype for regulation of insulin receptor signaling. ${ }^{92}$ Previous studies on $\beta 2-\mathrm{AR}$ in vivo and in vitro in heart, lung, and kidney tissues have suggested it to be $\mathrm{G}_{\mathrm{s}}$ driven, while other studies using pertussis toxin have suggested that $\beta 2$-AR signaling may be also coupled to $G_{i}$ cascade cardiac tissue. $^{113-119}$ To determine whether $\beta 2$-adrenergic receptors on retinal Müller cells are regulated by $\mathrm{G}_{\mathrm{s}}$ or $\mathrm{G}_{\mathrm{i}}$, we will knockdown PKA using siRNA, and determine whether 
insulin receptor signaling is mediated by $\mathrm{G}_{\mathrm{s}}$. Further studies will look at treatment of retinal Müller cells with pertussis toxin to evaluate the role of $\mathrm{G}_{\mathrm{i}}$ activation.

\section{Results}

\section{Knockdown of PKA Produces No Significant Changes in Insulin Receptor}

In our previous studies we have shown that insulin receptor phosphorylation is reduced in an high glucose environment in retinal Müller cells. ${ }^{92}$ In these, we investigated whether knockdown of PKA would alter the phosphorylation of the insulin receptor in a high glucose environment. Western blot analysis showed that knockdown of PKA resulted in a significant decrease in insulin receptor phosphorylation compared to $5 \mathrm{mM}$ glucose samples (Figure 4-1) $(* \mathrm{p}<0.05$ vs. $5 \mathrm{mM}$ glucose). Further analysis of PKA siRNA and PKA +sal samples show no change vs. $25 \mathrm{mM}$ glucose samples. As in previous studies, treatment with salmeterol alone significantly increased phosphorylation of insulin receptor compared to $25 \mathrm{mM}$ glucose samples (Figure 4-1) $\left({ }^{\#} \mathrm{p}<0.05\right.$ vs. $25 \mathrm{mM}$ glucose samples). These results suggest that phosphorylation of insulin receptor is only partially mediated by PKA.

\section{Loss of PKA Decreases Phosphorylation of Akt Levels while Increasing Phosphorylation of IRS-1 ${ }^{\text {Ser } 307}$}

Phosphorylation of Akt is important modulator of anti-apoptotic events in insulin receptor signaling in the retina. Decreased PKA levels by PKA siRNA and in PKA siRNA + salmeterol samples resulted in a significant decrease in Akt phosphorylation compared to both $5 \mathrm{mM}$ and $25 \mathrm{mM}$ glucose samples in retinal Müller cells (Figure 4-2A) $\left({ }^{*} p<0.05\right.$ vs. $5 \mathrm{mM}$ glucose, ${ }^{\#} \mathrm{p}<0.05$ vs. $25 \mathrm{mM}$ glucose $)$. Salmeterol alone treatments significantly increased Akt phosphorylation vs. PKA siRNA + salmeterol samples (Figure 4-2A) $\left({ }^{\$} \mathrm{p}<0.05\right.$ vs. PKA siRNA + salmeterol). These results suggest that Akt phosphorylation in retinal Müller cells signals in a PKA-dependent manner.

Previous findings have suggested that loss of Akt phosphorylation in hyperglycemia may be attributed to significantly increased phosphorylation of IRS-1 ${ }^{\text {Ser } 307}$ on retinal Müller cells. ${ }^{92}$ Results showed a significant increase in phosphorylation on IRS-1 ${ }^{\text {Ser307 }}$ in PKA siRNA samples vs. $5 \mathrm{mM}$ glucose samples as well as $25 \mathrm{mM}$ glucose samples (Figure 4-2B) $\left({ }^{*} \mathrm{p}<0.05\right.$ vs. $5 \mathrm{mM}$ glucose samples, ${ }^{\#} \mathrm{p}<0.05$ vs. $25 \mathrm{mM}$ glucose samples) Further analysis shows that treatment with PKA siRNA + salmeterol results in a significant increase in IRS- $1{ }^{\text {Ser307 }}$ phosphorylation vs. $5 \&$ $25 \mathrm{mM}$ glucose samples (Figure 4-2B) $\left({ }^{*} \mathrm{p}<0.05\right.$ vs. $5 \mathrm{mM}$ glucose samples, ${ }^{\#} \mathrm{p}<0.05$ vs. $25 \mathrm{mM}$ glucose samples). Treatment with salmeterol alone samples resulted in a significant decrease IRS-1 ${ }^{\text {Ser307 }}$ phosphorylation vs. $25 \mathrm{mM}$ glucose samples \& PKA siRNA + salmeterol samples (Figure 4-2B) $\left({ }^{\#} \mathrm{p}<0.05\right.$ vs. $25 \mathrm{mM}$ glucose samples, ${ }^{\$} \mathrm{p}<0.05$ vs. PKA siRNA + salmeterol). Our findings here suggest that IRS $-1{ }^{\text {Ser307 }}$ phosphorylation signaling to Akt in retinal Müller cells is mediated by $\mathrm{G}_{\mathrm{s}}$ via PKA. 


\section{$95 \mathrm{kD}=-\longrightarrow$ P-Insulin Receptor \\ $95 \mathrm{kD}=0 \mathrm{Insulin}$ Receptor}

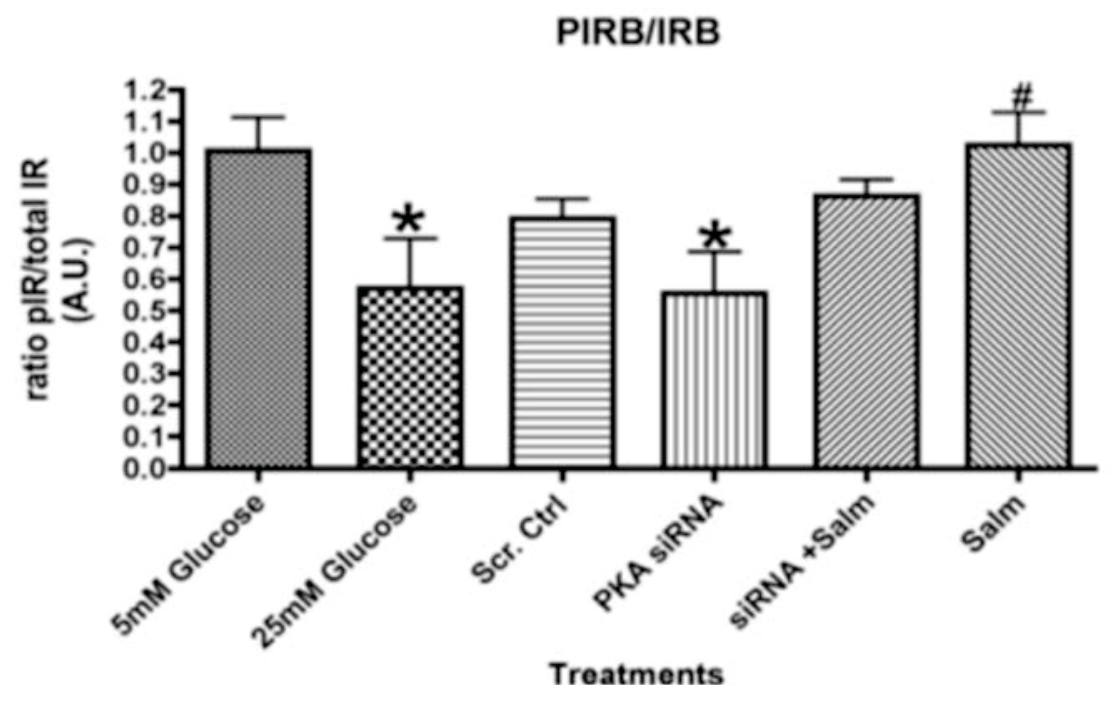

Figure 4-1. Knockdown of PKA shows little change in phosphorylation of insulin receptor

Protein analysis of Protein Kinase A (PKA) siRNA for the ratio of phosphorylation on insulin receptor showed no change compared to high glucose samples. However PKA siRNA was significantly different vs. $5 \mathrm{mM}$ glucose $\left({ }^{*} \mathrm{p}<0.05\right.$ vs. $5 \mathrm{mM}$ glucose).

Salmeterol (Salm) alone treated samples were significantly increased vs. high glucose samples $\left({ }^{\#} \mathrm{p}<0.05\right.$ vs. $25 \mathrm{mM}$ glucose samples $\left.n=4\right)$. 
A.

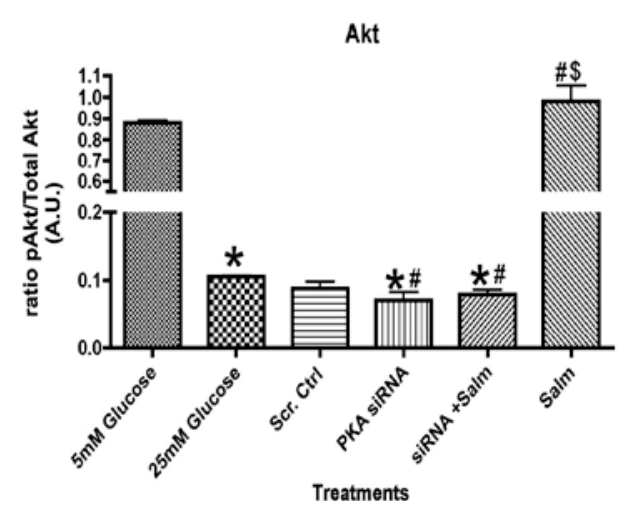

B. $180 \mathrm{kD}=0 \mathrm{~m}=\mathrm{PIRS}-1$ Ser 307 $180 \mathrm{kD}-\boldsymbol{-}-\boldsymbol{-}-\mathrm{IRS}-1$

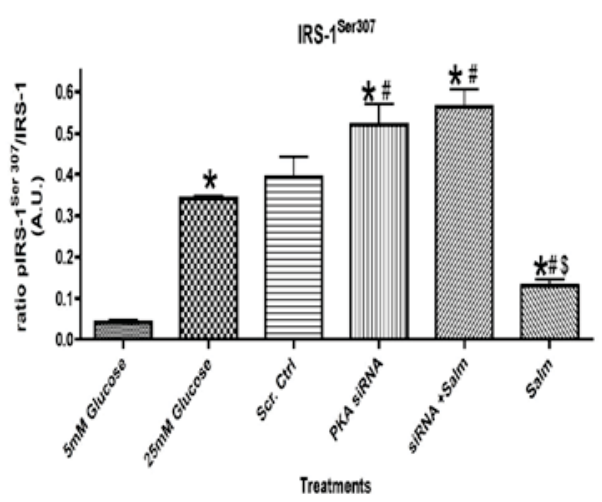

Figure 4-2. PKA siRNA decreases phosphorylation of Akt

(A) Western blot analysis of Protein Kinase A (PKA) siRNA on phosphorylation of Akt, PKA siRNA and PKA + salmeterol significantly decreased phosphorylation of Akt vs. high glucose samples $\left({ }^{\#} \mathrm{p}<0.05\right.$ vs. $25 \mathrm{mM}$ glucose samples). (B) Treatment with PKA siRNA also significantly increased levels of phosphorylation on IRS $-1^{\operatorname{Ser} 307}(\stackrel{\#}{*}<0.05$ vs. $25 \mathrm{mM}$ glucose samples). PKA siRNA + salmeterol further increased phosphorylation on IRS-1 ${ }^{\text {Ser307 }}\left({ }^{\#} \mathrm{p}<0.05\right.$ vs. $25 \mathrm{mM}$ glucose samples $)$. Salmeterol alone samples were significantly decreased vs. High glucose samples and vs. PKA siRNA + salmeterol samples ( ${ }^{*} \mathrm{p}<0.05$ vs. $5 \mathrm{mM}$ glucose samples $n=5,{ }^{\#} \mathrm{p}<0.05$ vs. $25 \mathrm{mM}$ glucose samples $n=5$, ${ }_{\mathrm{p}}<0.05$ vs. PKA siRNA + salmeterol $n=5$ ). 


\section{Dual Coupling of $G_{\mathbf{s}} / G_{i}$ Decreases Cell Death in Retinal Müller Cells}

Retinal Müller cells cultured in high glucose showed a significant increase in cell death in comparison to $5 \mathrm{mM}$ glucose samples (Figure 4-3) $\left({ }^{*} \mathrm{p}<0.05\right.$ vs. $5 \mathrm{mM}$ glucose sample). Knockdown of PKA showed a significant increase in cell death compared to $5 \mathrm{mM}$ glucose samples, however the PKA siRNA alone samples did not show any significant changes vs. $25 \mathrm{mM}$ glucose samples. Combination treatments of PKA siRNA + salmeterol yielded a significant decrease in cell death vs. $25 \mathrm{mM}$ glucose samples (Figure 4-3) $\left({ }^{\#} \mathrm{p}<0.05\right.$ vs. $25 \mathrm{mM}$ glucose samples). Activation of Gi by pertussis toxin and pertussis toxin + salmeterol resulted in significant decrease in cell death vs. $25 \mathrm{mM}$ glucose samples (Figure 4-3) ( ${ }^{*} \mathrm{p}<0.05$ vs. $25 \mathrm{mM}$ glucose samples). Treatment with salmeterol alone showed a significant decrease in cell death vs. $25 \mathrm{mM}$ glucose samples and PTX + salmeterol samples (Figure 4-3) $\left(^{\#} \mathrm{p}<0.05\right.$ vs. $25 \mathrm{mM}$ glucose samples, ${ }^{\$} \mathrm{p}<0.05$ vs. PTX + salmeterol). The findings here suggest that beta-adrenergic receptors signal through both PKA-dependent $\left(\mathrm{G}_{\mathrm{s}}\right)$ and -independent manner $\left(\mathrm{G}_{\mathrm{i}}\right)$ to reduce cell death in retinal Müller cells.

\section{Activation of $\mathbf{G}_{\mathrm{i}}$ Does Not Effect Insulin Receptor Phosphorylation in Retinal Müller Cells}

Further studies using PTX treatments on retinal Müller cells show a significant decrease in phosphorylation of insulin receptor compared to $5 \mathrm{mM}$ glucose samples (Figure 4-4) $(* p<0.05$ vs. $5 \mathrm{mM}$ glucose), but as in the case with PKA siRNA studies show no significant change when compared to high glucose samples. The mechanism by which stimulation of $\beta 2$-adrenergic receptors results in increased phosphorylation of insulin receptor treatment (Figure 4-4) $\left({ }^{\#} p<0.05\right.$ vs. $25 \mathrm{mM}$ glucose sample) continues to be unknown.

\section{Pertussis Toxin Treatment Causes Increase in Phosphorylation of Akt}

Western blot analyses showed that Müller cells treated with PTX and $\mathrm{PTX}+$ salmeterol significantly increased phosphorylation of Akt in comparison to protein levels in high glucose samples (Figure 4-5A) (\#p $<0.05$ vs. $25 \mathrm{mM}$ glucose). PTX treatment alone and combination treatment of PTX + salmeterol significantly decreased IRS-1 ${ }^{\text {Ser307 }}$ phosphorylation in a high glucose environment (Figure 4-5B) $(\# p<0.05$ vs. $25 \mathrm{mM}$ glucose). Activation of Gi by PTX results in an increase in anti-apoptotic, Akt by decreasing IRS-1 ${ }^{\text {Ser307 }}$ phosphorylation, which is a novel finding in retinal Müller cells. These findings are indicative a possible switch from $\mathrm{Gs}$ to $\mathrm{Gi}$ in order to provide an anti-apoptotic signal for stimulation of $\beta 2$-adrenergic receptors.

\section{Discussion}

The signaling of $\mathrm{G}$ protein-coupled receptors (GPCR) is composed of a wide range of stimuli, such as neurotransmitters and hormones to name a few. ${ }^{120,121}$ This wide 


\section{Cell Death}

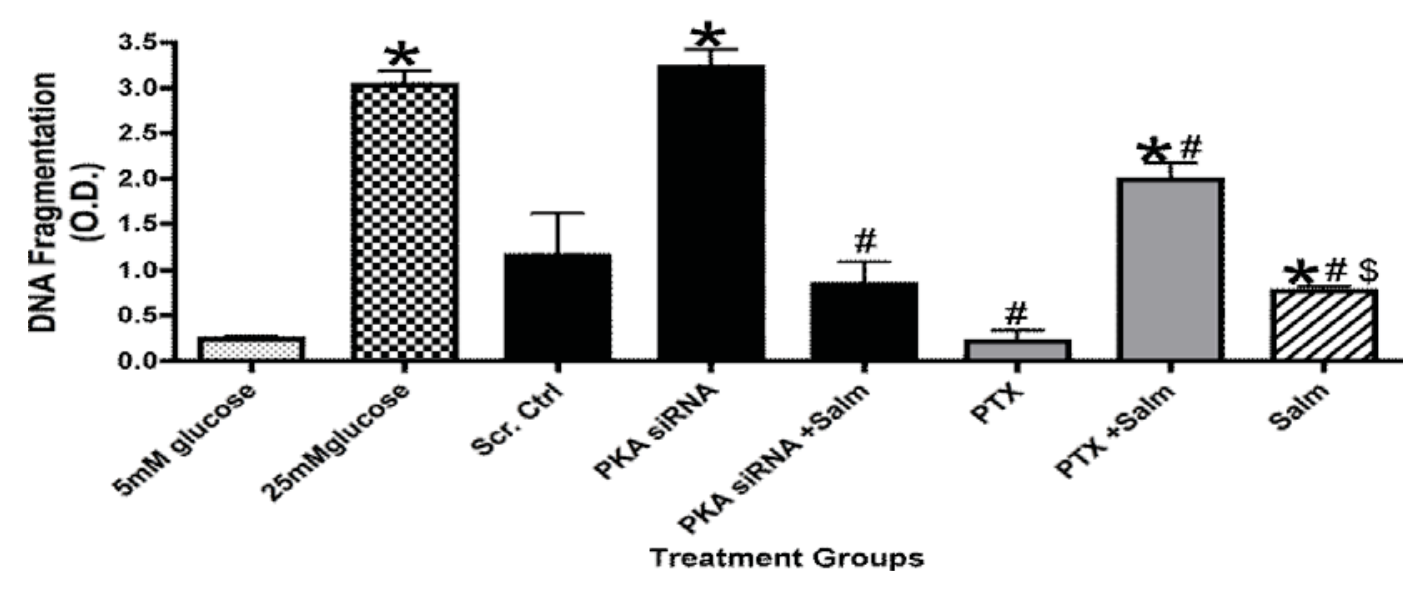

Figure 4-3. Treatment with PTX reduces cell death

Cell Death ELISA displayed a significant decrease in Protein Kinase A (PKA) siRNA + salmeterol vs. high glucose samples ( ${ }^{\#} \mathrm{p}<0.05$ vs. $25 \mathrm{mM}$ glucose samples $)$. Treatment with Pertussis Toxin (PTX) showed a significant decrease in cell death in comparison to high glucose samples ( ${ }^{\#} \mathrm{p}<0.05$ vs. $25 \mathrm{mM}$ glucose samples)

PTX + salmeterol (Salm) also showed a significant decrease in cell death vs.high glucose samples ( ${ }^{\#} p<0.05$ vs. $25 \mathrm{mM}$ glucose samples). Salmeterol alone samples showed a significant decrease in cell death vs. high glucose samples as well as PTX + salmeterol samples $\left({ }^{*} \mathrm{p}<0.05\right.$ vs. $5 \mathrm{mM}$ glucose samples $n=5,{ }^{*} \mathrm{p}<0.05$ vs. $25 \mathrm{mM}$ glucose samples $n=5,{ }^{\$} \mathrm{p}<0.05$ vs. PTX + salmeterol $n=5$ ). 


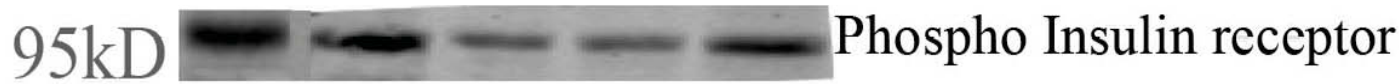
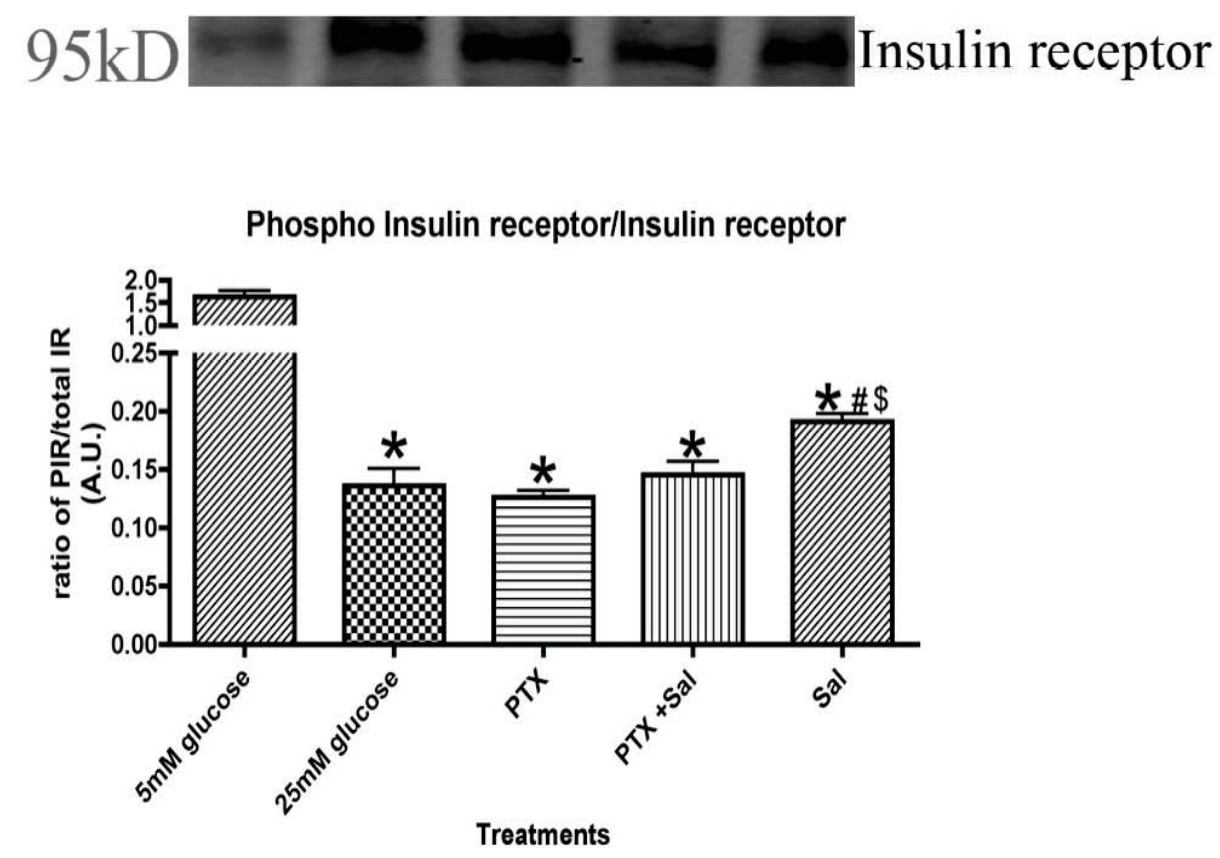

Figure 4-4. PTX treatment shows no effect on phosphorylation of insulin receptor

Mean densitometry showed Pertussis Toxin (PTX) \& PTX +salmeterol (Sal) treated samples had a significant decrease in phosphorylation of insulin receptor in comparison to high glucose samples $(* \mathrm{p}<0.05$ vs. $5 \mathrm{mM}$ glucose). Salmeterol alone samples showed a significant increase in ratio of IR ( $\# \mathrm{p}<0.05$ vs. $25 \mathrm{mM}$ glucose $n=5)$. 
A.
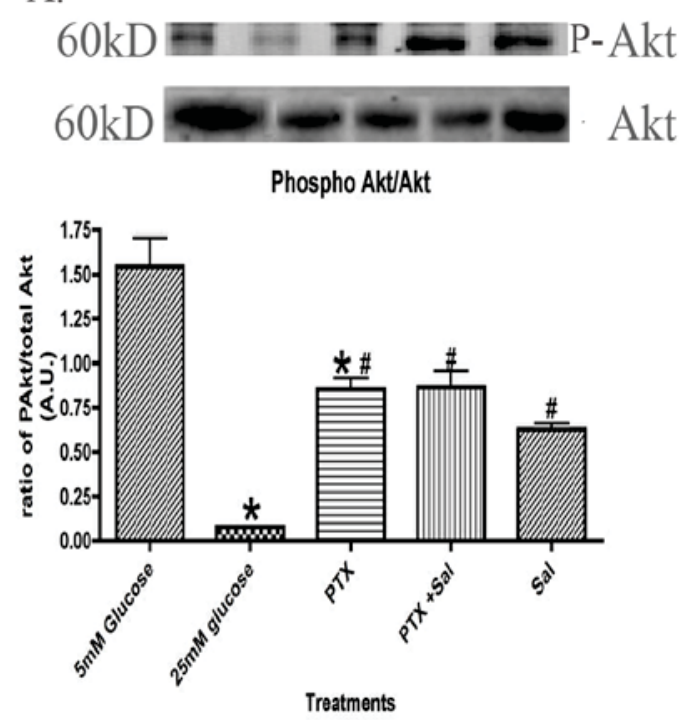

B.

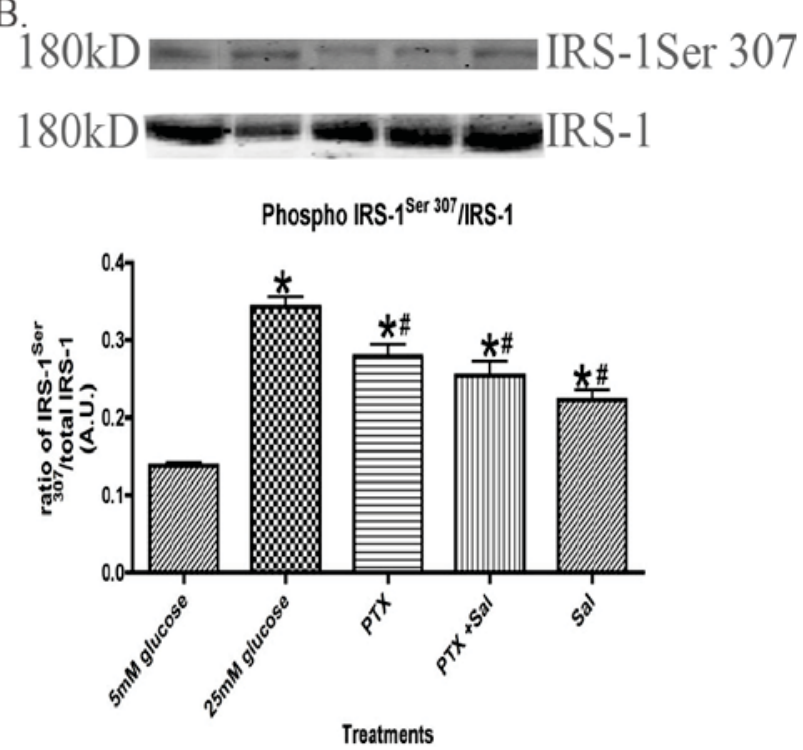

Figure 4-5. Treatment with PTX leads to increased Akt phosphorylation

(A) Mean densitometry of phosphorylation showed that activation of Gi causes a significant increase in phosphorylation of Akt in comparison to non-treated high glucose samples (\#p<0.05 vs. $25 \mathrm{mM}$ Glucose). PTX + salmeterol also showed a significant increase compared to high glucose samples ( $\# p<0.05$ vs. $25 \mathrm{mM}$ Glucose). (B) Western blot analysis of phosphorylation of IRS-1 ${ }^{\text {Ser307 }}$ showed a significant decrease in PTX alone and PTX + salmeterol samples compared to high glucose samples ( $\# \mathrm{p}<0.05 \mathrm{vs.}$ $25 \mathrm{mM}$ Glucose, $\$ \mathrm{p}<0.05$ vs. PTX + salmeterol). Treatment with salmeterol alone also significantly decreased phosphorylation levels of IRS $-1^{\text {Ser307 }}$ in Müller cells $(\# p<0.05$ vs. $25 \mathrm{mM}$ Glucose) . Significance was determined by one-tailed, non-parametric Mann-Whitney tests on western blot data ( $\# \mathrm{p}<0.05$ vs. $25 \mathrm{mM}$ Glucose, $\$ \mathrm{p}<0.05$ vs. PTX + salmeterol $\mathrm{n}=4, * \mathrm{p}<0.05$ vs. $5 \mathrm{mM}$ Glucose, $n=4$ ). 
range of signaling is able to mediate different responses throughout normal body and also suggested to be disrupted in a diseased body state. One of the diseases, which may involve loss of GPCR signaling, is diabetes, specifically diabetic retinopathy. The common GPCR, beta-adrenergic receptors have been previously shown to lose signaling capabilities with the onset of diabetes in various tissues throughout the body including the eye. ${ }^{28,29,92,96,122}$

Recent studies from our lab have identified the $\beta 2$-adrenergic receptor as the dominant receptor subtype in regulation of insulin receptor signaling in retinal Müller cells. $^{92}$ Stimulation of the receptor with a selective $\beta 2$-adrenergic receptor agonist, salmeterol, restored phosphorylation of insulin receptor and Akt, as well as decreased cell death in a high glucose environment. ${ }^{92}$ The mechanism by which stimulation of $\beta 2$-adrenergic receptors leads altered TNF- $\alpha$ and IRS-1 signaling is unclear. It is well documented that stimulation of beta-adrenergic receptors typically activate cAMP, leading to phosphorylation of PKA via $\mathrm{G}_{\mathrm{s}},{ }^{7,8}$ however recent findings have suggested that $\beta 2$-adrenergic receptors use a switching mechanism between $G_{s}$ and $G_{i}$ of the alpha subunit in cardiac myocytes. ${ }^{123}$

In our studies, knockdown of PKA with siRNA in retinal Müller cells resulted in a significant decrease in phosphorylation of Akt and insulin receptor in PKA alone compared to high glucose samples (Figures 4-1 and 4-2A). Salmeterol alone treatments significantly increased phosphorylation Akt and insulin receptor, but also were significantly increased compared to combination treatment of PKA siRNA + salmeterol (Figures 4-1 and 4-2A, respectively). Silencing of PKA and combination treatment of

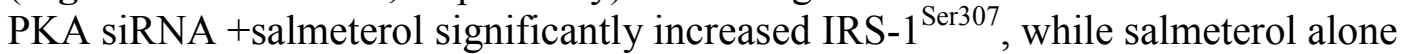
treatment significantly reduced Ser 307 phosphorylation on IRS-1 (Figure 4-2B). Findings from these studies indicate that restoration of insulin receptor signaling is partially mediated by PKA via $\mathrm{G}_{\mathrm{s}}$. However these findings did not extend to cell death in retinal Müller cells, as PKA knockdown significantly increased cell death vs. $5 \mathrm{mM}$ glucose, but failed to show any significant increases in cell death vs. $25 \mathrm{mM}$ glucose samples (Figure 4-3). However results from the cell death ELISA suggest a "switching" from $\mathrm{G}_{\mathrm{s}} / \mathrm{G}_{\mathrm{i}}$ based upon $\mathrm{G}_{\mathrm{i}}$ activation by pertussis toxin (PTX) treatment in retinal Müller cells. Treatment with pertussis toxin alone, and combination treatment of pertussis toxin + salmeterol significantly decreased cell death in retinal Müller cells vs. $25 \mathrm{mM}$ glucose.

Additional studies using pertussis toxin treatment on retinal Müller cells suggested no significant changes in phosphorylation of insulin receptor signaling, although there was a significant decrease in PTX alone and PTX+sal compared to normal glucose; however, these changes were likely attributed to the PTX treatments occurring in a $25 \mathrm{mM}$ glucose environment (Figure 4-4). Activation of $\mathrm{G}_{\mathrm{i}}$ by PTX resulted in significant increases in phosphorylation of Akt, which correlated with the decreases in phosphorylation of IRS-1 ${ }^{\text {Ser } 307}$ (Figure 4-5A and B). PTX + salmeterol also resulted in significant changes in phosphorylation in both Akt and IRS-1 ${ }^{\text {Ser } 307}$ (Figure 4-5A and B). 
Our findings suggest that PKA is needed for $\beta 2$-adrenergic receptor coupling of $\mathrm{G}_{\mathrm{s}}$ to $\mathrm{G}_{\mathrm{i}}$ proteins to reduce cell death in a diabetic like environment. Activation of $\mathrm{G}_{\mathrm{i}}$ and reduced coupling to $G_{s}$ on $B 2$-adrenergic receptors result in activation of Akt and other cell survival mechanisms in retinal Müller cells. Our findings presented here are in line with previous findings from heart studies that suggested a dual Gs/Gi coupling mechanism to prevent apoptosis. ${ }^{118,123}$ Previous studies in our lab using primary cultures of human retinal endothelial cells with treatment of a selective $\beta 1$-adrenergic receptor agonist, in a high glucose environment showed significant increases in PKA levels through 15-45 minute treatments. ${ }^{124}$ These results suggest that stimulation of $\beta 1$ adrenergic receptors activate the signaling of $\mathrm{G}_{\mathrm{s}}$-adenylyl cyclase-cAMP-PKA, which is in contrast to the findings reported here on $B 2$-adrenergic receptors.

The differences in the $\beta 1$-adrenergic receptor and $\beta 2$-adrenergic receptor using different $G$ protein subunits to signal may be related to a difference in structure in the B2-adrenergic receptor G-protein transmembrane regions. ${ }^{12}$ Studies have shown that specific $\mathrm{G}$ protein signaling for $\beta$-adrenergic receptors is modulated by the third intracellular loop. ${ }^{12}$ B2-adrenergic receptors possess a shorter third intracellular loop that is saturated with proline motifs; the result of this proline motif saturation results reduced efficiency of $\mathrm{G}_{\mathrm{s}}$ coupling. ${ }^{112}$ Studies provided by Xiao et al., found that by substituting the third intracellular loop of $\beta 1$-adrenergic receptors into that of $\beta 2$-adrenergic receptors resulted in a switch in the 31 -adrenergic receptor to use both $\mathrm{G}_{\mathrm{i}}$ and $\mathrm{G}_{\mathrm{s}}$ signaling pathways. ${ }^{112}$ Those studies provided further evidence in differences between betaadrenergic receptor subtypes.

For the first time to our knowledge, we show that $\beta 2$-adrenergic receptors in retinal Müller cells undergo a PKA-mediated dual coupling from $\mathrm{G}_{\mathrm{s}}$ to $\mathrm{G}_{\mathrm{i}}$ protein to provide anti-apoptotic signaling in a high glucose environment. Future studies will look to further delineate the difference in $G$ protein coupling in different $\beta$-adrenergic receptor subtypes specifically $\beta 1$ - and $\beta 2$-adrenergic receptors. The use of $\beta 1$ and $\beta 2$-adrenergic receptor knockout mice may provide the answer since the each subtype knockout mice will theoretically have different signaling patterns. Characterization of the $\mathrm{G}$ protein signaling in these mice will answer and provide unknown knowledge in retinal tissues. Knowledge from those studies would have might give more insight in treatment strategies based on $\beta$-adrenergic receptors in the progression of diabetic retinopathy. 


\section{CHAPTER 5. GENERAL DISCUSSION}

Diabetic retinopathy is a major complication of diabetes, and the leading cause of vision loss in working age people in the United States. ${ }^{39,59,103,122,125-127}$ At a 2007 summer meeting of the Association for Research in Vision and Ophthalmology, it was suggested that diabetic retinopathy be defined as "structural and functional changes in the retina due to diabetes." The hyperglycemic environment caused by diabetes produces a number of vascular and neuronal changes in the retina, making the disease very difficult to describe and develop treatments.

Previous studies on diabetic animal models have observed changes in the retina, initiated within weeks after the onset of diabetes to vascular changes occurring after 6-8 months of diabetes. ${ }^{37,39,103,128-130}$ These studies have described various complications such as pericyte loss, acellular capillaries, basement membrane thickening, activated glial cells and inflammation occurring within the neurosensory retina. ${ }^{37,39,103,129,130}$ Unfortunately, work in animal models do not progress to the proliferative phase of diabetic retinopathy. ${ }^{125}$ The exact mechanism of how high glucose levels contribute to the vascular and neuronal complications seen in diabetic retinopathy are not well understood, needing additional investigations to fully understand the pathology of this disease from the onset to visual loss.

The majority of investigations surrounding the pre-proliferative stages of the disease have concentrated on animal studies, with a focus on pericytes and endothelial cells. The studies presented in this dissertation focused on a different cell type, retinal Müller cells. Müller cells are the principal glial cell in the retina, and along with other glia cells (astrocytes, and microglia) make up roughly $95 \%$ of the retina. ${ }^{131}$ Müller cells play an important role in the retina by providing nutrients to blood vessels, regulating ion concentrations, and initiating protection methods in times of stress. ${ }^{58,59,98,127,131,132}$ One of the earliest disruptions in diabetic retinopathy is the activation of retinal Müller cells leading to an increase in GFAP, indicative of a stress in the retinal environment. $^{29,53,59,62,99,127,131,133,134}$ Müller cells have previously been shown to be protective to the eye in a normal setting, but with the onset of diabetic retinopathy, these cells exhibit deleterious effects such as increases in inflammatory cytokines, growth factors, and other toxic effects. In addition to these effects, Müller cells have also been shown to possess insulin receptors, which are suggested to be impaired in diabetic retinopathy. ${ }^{39,52,58,95,122,125}$

Although elevated glucose levels characterize diabetes, the underlying cause for these complications can be attributed to deficiencies in the production or usage of insulin. Insulin is only able to mediate its actions by binding the insulin receptor, with the receptor propagating the signal to carry out various protein and energy requirements. Disruption in insulin receptor signaling results in impairment and complications observed in all tissues throughout the body, including the retina. Recent rodent studies have confirmed that insulin receptors are present in the retina in levels comparable to brain and liver. ${ }^{39}$ Since Müller cells possess insulin receptors, one of our goals was to investigate 
insulin signaling in Müller cells. Results from our studies (Chapter 2) show that phosphorylation of the insulin receptor is significantly decreased in Müller cells cultured in a high glucose environment. These findings are in agreement with previous findings from whole retina samples. ${ }^{39}$ While it is clear that insulin signaling occurs in Müller cells, the present work focuses on $\beta$-adrenergic receptor regulation of insulin signaling in these cells. These studies show for the first time that restoration of insulin receptor signaling can be obtained by use of non-selective (isoproterenol) and selective (salmeterol) beta adrenergic receptor agonists in cells cultured in hyperglycemic environments or diabetic animals. These results also show that stimulation of beta-2-adrenergic receptors can reduce cell death in retinal Müller cells, suggesting a signaling mechanism for TNF- $\alpha$ actions on insulin receptor signaling, resulting in cell death in retinal Müller cells.

Earlier work in our lab concentrated on the role of inflammatory cytokines specifically TNF- $\alpha$ and their role in diabetic retinopathy. The results of those studies concluded that by stimulating beta adrenergic receptors in retinal Müller cells that were cultured in a high glucose environment, we significantly reduced protein levels of various inflammatory cytokines such IL-1 $\beta$, ICAM-1, iNOS, and TNF- $\alpha{ }^{29}$ To continue those studies, we chose to concentrate one inflammatory cytokine, TNF- $\alpha$, and provide a possible mechanism leading to cell death in retinal Müller cells. TNF- $\alpha$ is one of the most targeted pro-inflammatory cytokines in studies of diabetic retinopathy, cancer, and diabetic neuropathy as well as many other diseases. ${ }^{54,135,136}$ The topic of inflammation and its relation to diabetic retinopathy is a well-documented hypothesis for a majority of the earlier changes that occur in the disease. ${ }^{31,135,137-141}$

Screening of retinal samples from diabetic patients has revealed increased levels of numerous inflammatory cytokines such as TNF- $\alpha$. Although is not uncommon for these inflammatory cytokines to be upregulated in stress responses to the body (i.e. tissue injury, cellular infection, etc.), excessive expression of these inflammatory cytokines can result in various complications and diseases. In diabetic animal studies, it has been suggested that the number of leukocytes and neutrophils are increased comparable to the levels of inflammatory cytokines, leading to leukostastis. Increases in inflammatory cytokines can lead to activation of NF- $\kappa$ B by removal of inhibitor of NF- $\kappa B(I-\kappa B)$, which is a known mediator of inflammation. ${ }^{31,138,142}$ These factors, along with many others, contribute to the thought that diabetic retinopathy is a chronic inflammatory disease.

Other contributing factors that correlate to diabetic retinopathy being an inflammatory disease are the ability of retinal Müller cells to release TNF- $\alpha$ upon activation. We have previously shown that levels of TNF- $\alpha$ are significantly increased in the presence of high glucose. These results lead us to hypothesize that the increase of TNF- $\alpha$ could lead to cell death in retinal Müller cells. Literature searches in adipocytes in other tissues revealed a possible mechanism that suggested that increases in TNF- $\alpha$ can stimulate phosphorylation of Ser 307 on IRS-1. IRS-1 ${ }^{\text {Ser307 }}$ leads to decreased Akt phosphorylation on Ser 473 and increased in cell death. Results from knockdown of TNF- $\alpha$ show that decreasing levels of TNF- $\alpha$ resulted in increase in phosphorylation of 
Akt, significant decreases in IRS-1 ${ }^{\text {Ser } 307}$ phosphorylation, and decrease in cell death. Although our shRNA experiments did not completely inhibit TNF- $\alpha$ levels in high glucose, the amount of knockdown was enough to produce significant changes to IRS-1 actions in retinal Müller cells.

In order to fully understand the role of insulin signaling on apoptosis of retinal Müller cells, it is important to determine the specific role of the IRS complex proteins, specifically IRS-1 in Müller cells. IRS-1's ability to mediate insulin's action becomes dysfunctional with the onset of diabetes, ${ }^{52,73,74}$ and becomes a target for TNF- $\alpha$ to mediate pro-apoptotic signals. Results from Chapter 2 indicate that the reduced IRS-1 signaling after shRNA results in a significant increase in cell death. Although the knockdown IRS-1 significantly decreased serine phosphorylation, tyrosine phosphorylation was decreased as well, enhancing the increase in cell death. Combination treatments of IRS-1 shRNA + Salmeterol showed significant increases in cell death compared to salmeterol alone treatments, suggesting the need for IRS-1 signaling to decrease cell death.

As shown in Chapters 2 and 3 of this dissertation, our findings are in line with the findings in adipocytes, ${ }^{73,74,136}$ but contrast recent reports published in our field that state that IRS-2, not IRS-1, is the major player in the role of insulin signaling in the retina. ${ }^{39}$ The discrepancies in our findings compared to previous studies in our field likely stem from the fact that we concentrated solely on in vitro studies using retinal Müller cells. Previous studies have dealt with in vivo and ex vivo studies using whole retinal samples, which contain a variety of retinal cell types. There are 4 subtypes of the insulin receptor substrate complex (IRS 1-4), and out of these four; two of these subtypes, IRS-1 and IRS-2 play a major role in insulin signaling throughout the body. In other work from our lab, we have found differences in insulin receptor substrate signaling in retinal endothelial cells, which tend to signal through an IGF-1 receptor/IRS-2-dependent mechanism compared to retinal Müller cells which signal through an IR/ IRS-1 mechanism. Insulin studies have shown that mechanism of action for insulin is to signal through insulin receptors, which consists of two alpha subunits and two beta subunits, ${ }^{37,39}$ however the makeup of IGF-1 receptor is very similar and for that reason have similar signaling paths. The actions of insulin are initiated when the receptor becomes bound on the alpha subunits and this binding causes a phosphorylation on tyrosine kinases of the beta subunits inducing a conformational change. ${ }^{37,39}$ In most cases the lack of expression insulin receptors can promote IGF-1 receptors to form a tetrameric receptor making it difficult to delineate which receptors are responsible for the cellular signaling through the IRS-1 complexes. ${ }^{75,136}$ These studies provide a rationale suggesting that different cell types in the retina may use different subtypes of the IRS complex for cellular signaling, which expands the signaling possibilities of retinal cells.

Our studies have shown that high glucose can cause inhibition of beta-adrenergic receptor activation of signaling molecules, such as phosphatidylinositol-3-kinase (PI3K) and IRS-1. ${ }^{47}$ Inhibition of these signaling molecules can significantly alter the interactions of beta-adrenergic receptors and insulin receptor. It is well known that betaadrenergic receptors primarily signal through PKA. Results from Chapter 4 confirm that 
loss of PKA signaling by siRNA leads to further inhibition of beta-adrenergic receptor signaling. Significant inhibition of PKA significantly decreased the phosphorylation of Akt, as well as significantly increases the phosphorylation of IRS-1 on serine 307 in retinal Müller cells. Silencing of PKA also increased cell death compared to normal glucose samples, however no significant differences in cell death were seen in high glucose samples compared to PKA siRNA samples. Combination treatment with salmeterol + PKA siRNA showed a significant decrease in cell death, suggesting a compensatory mechanism for alternate signaling when the PKA signal is disrupted. Our findings are very thought provoking in that we are the first to our knowledge to show the mechanism of PKA signaling in retinal Müller cells, since it is known that PKA is supposed to be the essential step in beta-adrenergic receptor regulation.

One possible link between beta-adrenergic receptors and insulin receptor signaling might be an upregulation of $\beta 2 A R$-coupled $G_{i}$ signaling. While we have shown that loss PKA leads to significant decreases in Akt and phosphorylation, we also reported that loss of PKA showed no significant changes in cell death when compared to high glucose samples. While it is well understood that majority of beta-adrenergic receptor stimulation results from PKA activation by $\mathrm{G}_{\mathrm{s}}$, we have reason to believe that in retinal Müller cells, dual coupling (utilizing $\mathrm{G}_{\mathrm{s}}$ and $\mathrm{G}_{\mathrm{i}}$ to signal simultaneously) may occur. Results from our cell death assay showed that in combination treatments with PKA siRNA + salmeterol, there was a significant decrease in cell death. Additional findings showed that treatment with pertussis toxin (PTX), an inhibitor of $\mathrm{G}_{\mathrm{i}}$, significantly decreased cell death levels also. These findings agree with previous literature in the heart has shown that beta-2-adrenergic possess an innate ability to signal through numerous pathways by dual coupling to various members of the G protein family. ${ }^{112}$ This report also suggested that the inhibition of $\mathrm{G}_{i}$ was able to act in an anti-apoptotic manner, which is very similar to our findings in Chapter 4 . Further reports are substantiated by studies in $32 \mathrm{AR}$ knockout mice that found that stimulation of the beta-2-adrenergic receptor showed very contrasting signaling mechanisms than that of the beta-1-knockout mice following stimulation. Although there was increased accumulation of cAMP verified by assay in the animals, the animals showed no effects when given PKA inhibitors suggesting an alternate pathway. ${ }^{123}$ The findings from Chapter 4 were in line with our original hypothesis, and upon further literature review, these findings are in agreement with findings in the heart. These findings are the first to our knowledge to report that retinal Müller cells signal through a PKA-dependent manner in a high glucose environment. Future studies will go more in depth mechanistically to confirm our initial findings, as well as identify possible trigger points for this dual signaling in this particular cell type.

From these works, future studies will hopefully be directed toward characterizations of insulin signaling in vivo to see whether findings from our in vitro studies are relevant in animal models. The best potential animal model to achieve these studies would be to use beta-2-adrenergic receptor knockout mice, which are commonly used for heart and lung studies. The potential findings from using retinal tissue lysates from these animals would give further evidence of changes that occur with altered sympathetic neurotransmission. We would hope to observe that insulin and/or IGF-1 
signaling is down regulated in the retina of these $\mathrm{KO}$ mice as compared to the heterozygote littermates. These results would strongly suggest that beta-2-adrenergic receptors mediate changes in insulin signaling in the retina, which may explain the protective effect of sympathetic neurotransmission on the retina. Alternatively, we could also make the beta-2-adrenergic receptor knockout and their wild-type littermates diabetic to determine if the role of the beta-2-adrenergic receptor only in times of systemic stressors, such as high glucose environment. These results would show that loss of beta-2-adrenergic receptor agonist could lead to increased expression of apoptotic markers observed when the retina is stressed due to high glucose.

The findings presented here in this dissertation add to a very limited body of work as it relates to insulin signaling and cell death in retinal Müller cells. For many years it was thought that the death of retinal Müller cells occurred via apoptosis. While this thought seemed to fall in line with data from other cell types in the retina, the work in our lab and findings from other labs have shown that apoptosis in retinal Müller cells does not occur. The inability to display common apoptotic DNA fragmentation via TUNEL staining, along with very minimal changes in cleaved caspase 3 levels in Müller cells cultured in a hyperglycemic environment has changed the thinking in the field.

Recent studies have suggested that increases in GAPDH nuclear accumulations in retinal Müller cells could be a potential mediator for cell death occurring in these cells. In a hyperglycemic environment, it is suggested that GAPDH translocation from the cytosol to the nucleus of Müller cells is stimulated by increase in nitric oxide as well as interleukin-1beta. ${ }^{143,144}$ The stimulation from pro-inflammatory cytokines, nitric oxide and interleukin-1beta, resulted in nuclear accumulation of GAPDH which resulted in significant increase in Caspases 1, 6, and 9. ${ }^{143,144}$ Although these studies are the first to suggest an alternative mechanism for cell death in retinal Müller cells in diabetic retinopathy, our results fall in line with some of their findings. Walker et al. 2007, showed that culturing Müller cells in a hyperglycemic environment resulted in increases in iNOS, as well as interleukin-1beta, and treatment with isoproterenol significantly decreased these inflammatory cytokines.

Studies in this dissertation add to the complex mechanism of cell death in retinal Müller cells, in my opinion, much additional work is needed to understand why Müller cells undergo such a different sequence of events in diabetic retinopathy than any other cell type. It has been estimated that $20 \%$ of Müller cells undergo cell death in the early progression of diabetic retinopathy, but the exact mechanism for how the death occurs is not clear. What we understand is that in normal conditions the Müller cells have a variety of housekeeping functions such as mediating glutamine uptake to and from neurons, production and secretions of proteins that make up the tight junctions of the blood retinal barrier, as well as being the only cell type that is in contact with all retinal cell types. ${ }^{131}$

One study that I would conduct to elucidate the mechanism of Müller cell survival and/or loss in diabetic retinopathy is to use some of the current rodent models, and label cells with a co GFAP/CRALBP/ glutamine synthetase marker. By targeting cells first with GFAP, one would be able to identify activated glial cells and then using CRALBP 
and glutamine synthetase which are both expressed by Müller cells and not by astrocytes, the theory would be that any cell that is triple labeled would be positively identified as Müller cells. A comparison of a diseased rodent model to a normal untreated counterpart would identify exactly how many Müller cells survived/die. This process would need to be carried out after 3-4 weeks of STZ injections, since we know that Müller cells undergo early changes in diabetic retinopathy. From these findings we could further use these labeled cells for microarray analysis, various proteomic analysis, and various microscopy analysis to further understand the mechanism of cell death and cell survival for this particular cell type in the retina.

In summary, it is important to understand that the lack of knowledge of Müller cells in diabetic retinopathy is much greater than the knowledge that we actually possess about this particular cell type. These studies have attempted to further our knowledge by dissecting out possible mechanisms of beta-adrenergic receptor regulation of TNF- $\alpha$ and insulin receptor actions in retinal Müller cells. We have shown a possible mechanism in which TNF- $\alpha$ regulates insulin receptor signaling by phosphorylating serine 307 on IRS-1 and this phosphorylation inhibit insulin action. ${ }^{31,38}$ The efforts in this study have provided further understanding in the regulation of insulin signaling in the retina and a potential role for beta-adrenergic receptors in diabetic retinopathy. 


\section{LIST OF REFERENCES}

1. Bylund DB, Eikenberg DC, Hieble JP, et al. International Union of Pharmacology nomenclature of adrenoceptors. Pharmacol Rev 1994;46:121-136.

2. Lands A M AA, McAuliff J P, Ludaena F P \& Brown T G, Jr. . Differentiation of receptor systems activated by sympathomimetic amines. Nature 1967;597-598.

3. Deupi X, Kobilka B. Activation of G Protein-Coupled Receptors. In: Stephen RS (ed), Advances in Protein Chemistry: Academic Press; 2007:137-166.

4. Frielle T, Caron M, Lefkowitz R. Properties of the beta 1- and beta 2-adrenergic receptor subtypes revealed by molecular cloning. Clin Chem 1989;35:721-725.

5. Lands A M AA, McAuliff J P, Ludaena F P \& Brown T G, Jr. . Differentiation of receptor systems activated by sympathomimetic amines. Nature 1967;597-598.

6. Chakraborti S, Chakraborti T, Shaw G. [beta]-adrenergic mechanisms in cardiac diseases:: A perspective. Cellular Signalling 2000;12:499-513.

7. Dell'Acqua ML, Smith KE, Gorski JA, Horne EA, Gibson ES, Gomez LL. Regulation of neuronal PKA signaling through AKAP targeting dynamics. European Journal of Cell Biology 2006;85:627-633.

8. Martin NP, Whalen EJ, Zamah MA, Pierce KL, Lefkowitz RJ. PKA-mediated phosphorylation of the $\beta 1$-adrenergic receptor promotes Gs/Gi switching. Cellular Signalling 2004;16:1397-1403.

9. Shaywitz AJ, Greenberg ME. CREB: A Stimulus-Induced Transcription Factor Activated by A Diverse Array of Extracellular Signals. Annual Review of Biochemistry 1999;68:821-861.

10. Steinle JJ, Booz GW, Meininger CJ, Day JN, Granger HJ. Beta 3-adrenergic receptors regulate retinal endothelial cell migration and proliferation. The Journal of biological chemistry 2003;278:20681-20686.

11. Abu-El-Asrar AM, Dralands L, Missotten L, Al-Jadaan IA, Geboes K. Expression of apoptosis markers in the retinas of human subjects with diabetes. Invest Ophthalmol Vis Sci 2004;45:2760-2766.

12. Giebel SJ, Menicucci G, McGuire PG, Das A. Matrix metalloproteinases in early diabetic retinopathy and their role in alteration of the blood-retinal barrier. Lab Invest 2005;85:597-607.

13. Jiang BH, Zheng JZ, Aoki M, Vogt PK. Phosphatidylinositol 3-kinase signaling mediates angiogenesis and expression of vascular endothelial growth factor in endothelial cells. Proc Natl Acad Sci U S A 2000;97:1749-1753.

14. Pepe S, van den Brink OWV, Lakatta EG, Xiao R-P. Cross-talk of opioid peptide receptor and beta-adrenergic receptor signalling in the heart. Cardiovascular Research 2004;63:414-422. 
15. DeWire SM, Ahn S, Lefkowitz RJ, Shenoy SK. E $\leq-$-Arrestins and Cell Signaling. Annual Review of Physiology 2007;69:483-510.

16. Moore CAC, Milano SK, Benovic JL. Regulation of Receptor Trafficking by GRKs and Arrestins. Annual Review of Physiology 2007;69:451-482.

17. Premont RT, Gainetdinov RR. Physiological Roles of G Protein, ÄiCoupled Receptor Kinases and Arrestins. Annual Review of Physiology 2007;69:511-534.

18. Dodge-Kafka KL, Kapiloff MS. The mAKAP signaling complex: Integration of cAMP, calcium, and MAP kinase signaling pathways. European Journal of Cell Biology 2006;85:593-602.

19. McConnachie G, Langeberg LK, Scott JD. AKAP signaling complexes: getting to the heart of the matter. Trends in Molecular Medicine 2006;12:317-323.

20. Smith FD, Langeberg LK, Scott JD. The where's and when's of kinase anchoring. Trends in Biochemical Sciences 2006;31:316-323.

21. Burnstock G. Changes in expression of autonomic nerves in aging and disease. JAutonNervSyst 1990;30 Suppl.:S25-S34.

22. Mei Q, Mundinger TO, Lernmark A, Taborsky GJ. Early, Selective, and Marked Loss of Sympathetic Nerves From the Islets of BioBreeder Diabetic Rats. Diabetes 2002;51:2997-3002.

23. Heller P, Perry F, Jewett D, Levine J. Autonomic components of the human pupillary light reflex. Invest Ophthalmol Vis Sci 1990;31:156-162.

24. Duong DK, Leo MM, Mitchell EL. Neuro-Ophthalmology. Emergency Medicine Clinics of North America 2008;26:137-180.

25. Laties AM, Jacobowitz D. A comparative study of the autonomic innervation of the eye in monkey, cat, and rabbit. Anat Rec 1966;156:383-395.

26. Furukawa H. Autonomic innervation of preretinal blood vessels of the rabbit. Invest Ophthalmol Vis Sci 1987;28:1752-1760.

27. Arthur D. Loewy KMS. Central regulation of autonomic functions Oxford University Press; 1990.

28. Wiley LA, Rupp GR, Steinle JJ. Sympathetic innervation regulates basement membrane thickening and pericyte number in rat retina. Invest Ophthalmol Vis Sci 2005;46:744-748.

29. Walker R, Steinle J. Role of Beta-adrenergic Receptors in Inflammatory Marker Expression in Muller Cells. Invest Ophthalmol Vis Sci 2007;48:5276-5281.

30. Steinle JJ, Lindsay NL, Lashbrook BL. Cervical sympathectomy causes photoreceptor-specific cell death in the rat retina. Auton Neurosci 2005;120:4651.

31. Hotamisligil GS. Inflammation and metabolic disorders. Nature 2006;444:860867. 
32. Tezel GaW, MB. Increased Production of Tumor Necrosis Factor-a by Glial Cells Exposed to Simulated Ischemia or Elevated Hydrostatic Pressure Induces Apoptosis in Cocultured Retinal Ganglion Cells. The Journal of Neuroscience 2000;20:8693-8700.

33. L Sekut BRC, K Page, J A Menius, Jr, and K M Connolly. Anti-inflammatory activity of salmeterol: down-regulation of cytokine production. Clin Exp Immunology 1995;3:461-466.

34. Saito K SK, Nishida K, Sei Y, Basile AS. Early increases in TNF-alpha, IL-6 and IL-1 beta levels following transient cerebral ischemia in gerbil brain. Neurosci Lett 1996;206:149-152.

35. Takashi $\mathrm{Y}$, Tsugiyasu K, Yasutaka K, et al. Inflammatory cytokines in vitreous fluid and serum of patients with diabetic vitreoretinopathy. Journal of diabetes and its complications 2001;15:257-259.

36. Walker RJ, Steinle JJ. Role of beta-adrenergic receptors in inflammatory marker expression in Muller cells. Invest Ophthalmol Vis Sci 2007;48:5276-5281.

37. Reiter CEN, Sandirasegarane L, Wolpert EB, et al. Characterization of insulin signaling in rat retina in vivo and ex vivo. Am J Physiol Endocrinol Metab 2003;285:E763-774.

38. Taniguchi CM, Emanuelli B, Kahn CR. Critical nodes in signalling pathways: insights into insulin action. Nat Rev Mol Cell Biol 2006;7:85-96.

39. Reiter CEN, Wu X, Sandirasegarane L, et al. Diabetes Reduces Basal Retinal Insulin Receptor Signaling. Diabetes 2006;55:1148-1156.

40. Das A PB, Budd GC, Kollarits CR. Immunocytochemistry of mouse and human retina with antisera to insulin and S-100 protein. Curr Eye Res 1984;3:1397-1403.

41. Reiter CE, Gardner TW. Functions of insulin and insulin receptor signaling in retina: possible implications for diabetic retinopathy. Prog Retin Eye Res 2003;22:545-562.

42. Reiter CE, Sandirasegarane L, Wolpert EB, et al. Characterization of insulin signaling in rat retina in vivo and ex vivo. Am J Physiol Endocrinol Metab 2003;285:E763-774.

43. Reiter CE, Wu X, Sandirasegarane L, et al. Diabetes reduces basal retinal insulin receptor signaling: reversal with systemic and local insulin. Diabetes 2006;55:1148-1156.

44. Das A, Pansky B, Budd GC. Demonstration of insulin-specific mRNA in cultured rat retinal glial cells. Invest Ophthalmol Vis Sci 1987;28:1800-1810.

45. Das A, Pansky B, Budd G. Demonstration of insulin-specific mRNA in cultured rat retinal glial cells. Invest Ophthalmol Vis Sci 1987;28:1800-1810. 
46. Gavi S, Yin D, Shumay E, Wang HY, Malbon CC. The 15-amino acid motif of the $\mathrm{C}$ terminus of the beta2-adrenergic receptor is sufficient to confer insulinstimulated counterregulation to the beta1-adrenergic receptor. Endocrinology 2005; 146:450-457.

47. Kawabe J, Aizawa Y, Takehara N, Hasebe N, Kikuchi K. Glucose modifies the cross-talk between insulin and the beta-adrenergic signalling system in vascular smooth muscle cells. J Hypertens 2000;18:1457-1464.

48. Walker RJ, Anderson NM, Bahouth S, Steinle JJ. Silencing of insulin receptor substrate-1 increases cell death in retinal Müller cells. Molecular Vision 2012;18: 271-279.

49. Klein R. Diabetic retinopathy. Annu Rev Public Health 1996;17:137-58:137-158.

50. El-Asrar AMA, Dralands L, Missotten L, Al-Jadaan IA, Geboes K. Expression of Apoptosis Markers in the Retinas of Human Subjects with Diabetes. Invest Ophthalmol Vis Sci 2004;45:2760-2766.

51. Frank RN. Diabetic retinopathy. N Engl J Med 2004;350:48-58.

52. Kondo T, Kahn CR. Altered Insulin Signaling in Retinal Tissue in Diabetic States. Journal of Biological Chemistry 2004;279:37997-38006.

53. Bringmann A, Pannicke T, Grosche J, et al. Muller cells in the healthy and diseased retina. Prog Retin Eye Res 2006;25:397-424.

54. Joussen AM, Doehmen S, Le ML, et al. TNF-alpha mediated apoptosis plays an important role in the development of early diabetic retinopathy and long-term histopathological alterations. Molecular vision 2009;15:1418-1428.

55. Mysona B, Dun Y, Duplantier J, Ganapathy V, Smith S. Effects of hyperglycemia and oxidative stress on the glutamate transporters GLAST and system x\&lt;sub\&gt;c\&lt;/sub\&gt;\&lt;sup\&gt;-\&lt;/sup\&gt; in mouse retinal Müller glial cells. Cell and Tissue Research 2009;335:477-488.

56. Tret'iak EB, Syroedova ON, Neuhaus O, et al. [Cytokines and their role in pathogenesis of diabetic retinopathy]. Vestnik oftalmologii 2010;126:53-57.

57. Trudeau K, Molina AJ, Guo W, Roy S. High glucose disrupts mitochondrial morphology in retinal endothelial cells: implications for diabetic retinopathy. The AmericanJjournal of Pathology 2010;177:447-455.

58. Curtis TM, Hamilton R, Yong PH, et al. Muller glial dysfunction during diabetic retinopathy in rats is linked to accumulation of advanced glycation end-products and advanced lipoxidation end-products. Diabetologia 2011;54:690-698.

59. Mizutani M, Gerhardinger C, Lorenzi M. Muller cell changes in human diabetic retinopathy. Diabetes 1998;47:445-449.

60. King JL, Guidry C. Muller cell production of insulin-like growth factor-binding proteins in vitro: modulation with phenotype and growth factor stimulation. Invest Ophthalmol Vis Sci 2004;45:4535-4542. 
61. Kusner LL, Sarthy VP, Mohr S. Nuclear translocation of glyceraldehyde-3phosphate dehydrogenase: a role in high glucose-induced apoptosis in retinal Muller cells. Invest Ophthalmol Vis Sci 2004;45:1553-1561.

62. Guidry C, King JL, Mason JO, III. Fibrocontractive Muller Cell Phenotypes in Proliferative Diabetic Retinopathy. Invest Ophthalmol Vis Sci 2009;50:19291939.

63. Fletcher EL, Phipps JA, Ward MM, Puthussery T, Wilkinson-Berka JL. Neuronal and glial cell abnormality as predictors of progression of diabetic retinopathy. Curr Pharm Des 2007;13:2699-2712.

64. Li Q, Puro DG. Diabetes-induced dysfunction of the glutamate transporter in retinal Muller cells. Invest Ophthalmol Vis Sci 2002;43:3109-3116.

65. Kowluru RA, Tang J, Kern TS. Abnormalities of retinal metabolism in diabetes and experimental galactosemia. VII. Effect of long-term administration of antioxidants on the development of retinopathy. Diabetes 2001;50:1938-1942.

66. Aguirre V, Werner ED, Giraud J, Lee YH, Shoelson SE, White MF. Phosphorylation of Ser307 in Insulin Receptor Substrate-1 Blocks Interactions with the Insulin Receptor and Inhibits Insulin Action. Journal of Biological Chemistry 2002;277:1531-1537.

67. Greene MW, Garofalo RS. Positive and Negative Regulatory Role of Insulin Receptor Substrate 1 and 2 (IRS-1 and IRS-2) Serine/Threonine Phosphorylation. Biochemistry 2002;41:7082-7091.

68. Hartman ME, Villela-Bach M, Chen J, Freund GG. FRAP-Dependent Serine Phosphorylation of IRS-1 Inhibits IRS-1 Tyrosine Phosphorylation. Biochemical and Biophysical Research Communications 2001;280:776-781.

69. Luo M, Langlais P, Yi Z, et al. Phosphorylation of Human Insulin Receptor Substrate-1 at Serine 629 Plays a Positive Role in Insulin Signaling. Endocrinology 2007;148:4895-4905.

70. Luo M, Reyna S, Wang L, et al. Identification of insulin receptor substrate 1 serine/threonine phosphorylation sites using mass spectrometry analysis: regulatory role of serine 1223. Endocrinology 2005;146:4410-4416.

71. Aguirre V, Uchida T, Yenush L, Davis R, White MF. The c-Jun NH(2)-terminal kinase promotes insulin resistance during association with insulin receptor substrate-1 and phosphorylation of Ser(307). The Journal of Biological Chemistry 2000;275:9047-9054.

72. Boura-Halfon S, Zick Y. Phosphorylation of IRS proteins, insulin action, and insulin resistance. Am J Physiol Endocrinol Metab 2009;296:E581-591.

73. Hotamisligil GS, Budavari A, Murray D, Spiegelman BM. Reduced tyrosine kinase activity of the insulin receptor in obesity-diabetes. Central role of tumor necrosis factor-alpha. J Clin Invest 1994;94:1543-1549. 
74. Hotamisligil GS, Peraldi P, Budavari A, Ellis R, White MF, Spiegelman BM. IRS-1-Mediated Inhibition of Insulin Receptor Tyrosine Kinase Activity in TNFalpha- and Obesity-Induced Insulin Resistance. Science 1996;271:665-670.

75. Paz K, Hemi R, LeRoith D, et al. A molecular basis for insulin resistance. Elevated serine/threonine phosphorylation of IRS-1 and IRS-2 inhibits their binding to the juxtamembrane region of the insulin receptor and impairs their ability to undergo insulin-induced tyrosine phosphorylation. The Journal of Biological Chemistry 1997;272:29911-29918.

76. Paz K, Liu YF, Shorer H, et al. Phosphorylation of insulin receptor substrate-1 (IRS-1) by protein kinase B positively regulates IRS-1 function. The Journal of biological chemistry 1999;274:28816-28822.

77. Sykiotis GP, Papavassiliou AG. Serine Phosphorylation of Insulin Receptor Substrate-1: A Novel Target for the Reversal of Insulin Resistance. Molecular Endocrinology 2001;15:1864-1869.

78. White MF. IRS proteins and the common path to diabetes. Am J Physiol Endocrinol Metab 2002;283:E413-422.

79. Kowluru RA. Diabetic Retinopathy: Mitochondrial Dysfunction and Retinal Capillary Cell Death. Antioxidants \& Redox Signaling 2005;7:1581.

80. Kowluru RA, Kennedy A. Therapeutic potential of anti-oxidants and diabetic retinopathy. Expert Opinion on Investigational Drugs 2001;10:1665-1676.

81. Hasnan J, Yusof MI, Damitri TD, Faridah AR, Adenan AS, Norbaini TH. Relationship between apoptotic markers (Bax and Bcl-2) and biochemical markers in type 2 diabetes mellitus. Singapore Medical Journal 2010;51:50-55.

82. Hetz C. BCL-2 protein family. Essential regulators of cell death. Preface. Advances in experimental medicine and biology 2010;687:vii-viii.

83. Khalfaoui T, Basora N, Ouertani-Meddeb A. Apoptotic factors (Bcl-2 and Bax) and diabetic retinopathy in type 2 diabetes. Journal of molecular histology 2010;41:143-152.

84. Soriano ME, Scorrano L. The interplay between BCL-2 family proteins and mitochondrial morphology in the regulation of apoptosis. Advances in Experimental Medicine and Biology 2010;687:97-114.

85. Lindsay J, Esposti MD, Gilmore AP. Bcl-2 proteins and mitochondria--specificity in membrane targeting for death. Biochimica et biophysica acta 2011;1813:532539.

86. Zhou F, Yang Y, Xing D. Bcl-2 and Bcl-xL play important roles in the crosstalk between autophagy and apoptosis. The FEBS Journal 2011;278:403-413.

87. Withers DJ, White M. Perspective: The Insulin Signaling System, ÄîA Common Link in the Pathogenesis of Type 2 Diabetes. Endocrinology 2000;141:1917-1921. 
88. Ueno H, Kondo E, Yamamoto-Honda R, et al. Association of Insulin Receptor Substrate Proteins with Bcl-2 and Their Effects on Its Phosphorylation and Antiapoptotic Function. Mol Biol Cell 2000;11:735-746.

89. Valverde AM, Mur C, Pons S, et al. Association of insulin receptor substrate 1 (IRS-1) y895 with Grb-2 mediates the insulin signaling involved in IRS-1deficient brown adipocyte mitogenesis. Molecular and Cellular Biology 2001;21:2269-2280.

90. Lorenzo M, Fernandez-Veledo S, Vila-Bedmar R, Garcia-Guerra L, De Alvaro C, Nieto-Vazquez I. Insulin resistance induced by tumor necrosis factor-alpha in myocytes and brown adipocytes. J Anim Sci 2008;86:E94-104.

91. Panjala S, Steinle J. Insulin and $\beta$-adrenergic Receptors Inhibit Retinal Endothelial Cell Apoptosis Through Independent Pathways. Neurochemical Research 2011;36:604-612.

92. Walker RJ, Anderson NM, Jiang Y, Bahouth S, Steinle JJ. Role of $\beta$-adrenergic receptors regulation of TNF- $\alpha$ and insulin signaling in retinal Müller cells. Investigative Ophthalmology \& Visual Science 2011.

93. Flynn HaS, WE. Diabetes and Ocular Disease. San Francisco: Foundation of the American Academy of Ophthalmology; 2000.

94. Barber AJ, Nakamura M, Wolpert EB, et al. Insulin Rescues Retinal Neurons from Apoptosis by a Phosphatidylinositol 3-Kinase/Akt-mediated Mechanism That Reduces the Activation of Caspase-3. Journal of Biological Chemistry 2001;276:32814-32821.

95. Bronson SK, Reiter CEN, Gardner TW. An eye on insulin. The Journal of Clinical Investigation 2003;111:1817-1819.

96. Williams KP, Steinle JJ. Maintenance of beta-adrenergic receptor signaling can reduce fas signaling in human retinal endothelial cells. Experimental Eye Research 2009;89:448-455.

97. Y. Kitagawa SA-A, T. Nagao. Determination of beta-adrenoceptor subtype on rat isolated ventricular myocytes by use of highly selective beta-antagonists. British Journal of Pharmacology 1995;1:1635-1643.

98. Fletcher EL, Downie LE, Ly A, et al. A review of the role of glial cells in understanding retinal disease. Clinical and Experimental Optometry 2008;91:6777.

99. Li Q, Puro DG. Diabetes-Induced Dysfunction of the Glutamate Transporter in Retinal Muller Cells. Invest Ophthalmol Vis Sci 2002;43:3109-3116.

100. Panjala SR, Jiang Y, Kern TS, Thomas SA, Steinle JJ. Increased tumor necrosis factor-alpha, cleaved caspase 3 levels and insulin receptor substrate-1 phosphorylation in the beta-adrenergic receptor knockout mouse. Molecular Vision 2011;17:1822-1828.

101. Jiang Y, Walker RJ, Kern TS, Steinle JJ. Application of isoproterenol inhibits diabetic-like changes in the rat retina. Exp Eye Res 2010;91:171-179. 
102. Rajala RV, Tanito M, Neel BG, Rajala A. Enhanced retinal insulin receptoractivated neuroprotective survival signal in mice lacking the protein-tyrosine phosphatase-1B gene. The Journal of Biological Chemistry 2010;285:8894-8904.

103. Rajala RV. Phosphoinositide 3-kinase signaling in the vertebrate retina. Journal of Lipid Research 2010;51:4-22.

104. Gottlob K, Majewski N, Kennedy S, Kandel E, Robey RB, Hay N. Inhibition of early apoptotic events by Akt/PKB is dependent on the first committed step of glycolysis and mitochondrial hexokinase. Genes \& development 2001;15:14061418.

105. Majewski N, Nogueira V, Bhaskar P, et al. Hexokinase-mitochondria interaction mediated by Akt is required to inhibit apoptosis in the presence or absence of Bax and Bak. Molecular cell 2004;16:819-830.

106. Kroeze WK, Sheffler DJ, Roth BL. G-protein-coupled receptors at a glance. Journal of Cell Science 2003;116:4867-4869.

107. Matteson PG, Desai J, Korstanje R, et al. The orphan G protein-coupled receptor, Gpr161, encodes the vacuolated lens locus and controls neurulation and lens development. Proc Natl Acad Sci U S A 2008;105:2088-2093.

108. Kristiansen K. Molecular mechanisms of ligand binding, signaling, and regulation within the superfamily of G-protein-coupled receptors: molecular modeling and mutagenesis approaches to receptor structure and function. Pharmacology \& Therapeutics 2004;103:21-80.

109. Rosenbaum DM, Rasmussen SGF, Kobilka BK. The structure and function of Gprotein-coupled receptors. Nature 2009;459:356-363.

110. Gether U, Kobilka BK. G Protein-coupled Receptors. Journal of Biological Chemistry 1998;273:17979-17982.

111. Mersmann HJ. Overview of the effects of beta-adrenergic receptor agonists on animal growth including mechanisms of action. J Anim Sci 1998;76:160-172.

112. Xiao R-P. \{beta\}-Adrenergic Signaling in the Heart: Dual Coupling of the \{beta\}2-Adrenergic Receptor to Gs and Gi Proteins. Sci STKE 2001;2001:re15-.

113. Fujita T, Ishikawa Y. Apoptosis in Heart Failure: The role of the $\beta$-adrenergic receptor-mediated signaling pathway and p53-mediated signaling pathway in the apoptosis of cardiomyocytes. Circulation Journal 2011;75:1811-1818.

114. Zhang W, Yano N, Deng M, Mao Q, Shaw SK, Tseng YT. $\beta$-adrenergic receptorPi3k signaling crosstalk in mouse heart: Elucidation of immediate downstream signaling cascades. PloS one 2011;6.

115. Bernstein D, Fajardo G, Zhao M. The role of $\beta$-adrenergic receptors in heart failure: Differential regulation of cardiotoxicity and cardioprotection. Progress in Pediatric Cardiology 2011;31:35-38. 
116. Somvanshi RK, Chaudhari N, Qiu X, Kumar U. Heterodimerization of $\beta 2$ adrenergic receptor and somatostatin receptor 5: Implications in modulation of signaling pathway. Journal of Molecular Signaling 2011;6.

117. Zhao M, Fajardo G, Urashima T, et al. Cardiac pressure overload hypertrophy is differentially regulated by $\beta$-adrenergic receptor subtypes. American Journal of Physiology - Heart and Circulatory Physiology 2011;301:H1461-H1470.

118. Zamah AM, Delahunty M, Luttrell LM, Lefkowitz RJ. Protein Kinase A-mediated Phosphorylation of the $\beta 2$-Adrenergic Receptor Regulates Its Coupling to Gs and Gi. Journal of Biological Chemistry 2002;277:31249-31256.

119. Penn RB, Panettieri RA, Jr., Benovic JL. Mechanisms of Acute Desensitization of the beta 2AR-Adenylyl Cyclase Pathway in Human Airway Smooth Muscle. Am J Respir Cell Mol Biol 1998;19:338-348.

120. Gilman AG. G proteins: transducers of receptor-generated signals. Annu Rev Biochem 1987;56:615-649.

121. Gu C, Ma YC, Benjamin J, Littman D, Chao MV, Huang XY. Apoptotic signaling through the beta -adrenergic receptor. A new Gs effector pathway. $J$ Biol Chem 2000;275:20726-20733.

122. Panjala SR, Steinle JJ. Insulin and beta-adrenergic receptors inhibit retinal endothelial cell apoptosis through independent pathways. Neurochemical Research 2011;36:604-612.

123. Devic E, Xiang Y, Gould D, Kobilka B. $\beta$-Adrenergic Receptor Subtype-Specific Signaling in Cardiac Myocytes from $\beta 1$ and $\beta 2$ Adrenoceptor Knockout Mice. Molecular Pharmacology 2001;60:577-583.

124. Steinle JJ, Chin VC, Williams KP, Panjala SR. Beta-adrenergic receptor stimulation modulates iNOS protein levels through p38 and ERK1/2 signaling in human retinal endothelial cells. Experimental Eye Research 2008;87:30-34.

125. Lloyd Paul Aiello. Diabetic Retinopathy: An Eye Toward the Future. Medscape Diabetes and Endocrinology; 2002.

126. Reza AW, Eswaran C, Dimyati K. Diagnosis of Diabetic Retinopathy: Automatic Extraction of Optic Disc and Exudates from Retinal Images using Markercontrolled Watershed Transformation. Journal of Medical Systems 2010.

127. Rungger-Brandle E, Dosso AA, Leuenberger PM. Glial Reactivity, an Early Feature of Diabetic Retinopathy. Invest Ophthalmol Vis Sci 2000;41:1971-1980.

128. Steinle JJ, Kern TS, Thomas SA, McFadyen-Ketchum LS, Smith CP. Increased basement membrane thickness, pericyte ghosts, and loss of retinal thickness and cells in dopamine beta hydroxylase knockout mice. Experimental Eye Research 2009;88:1014-1019.

129. Barber AJ, Lieth E, Khin SA, Antonetti DA, Buchanan AG, Gardner TW. Neural apoptosis in the retina during experimental and human diabetes. Early onset and effect of insulin. J Clin Invest 1998;102:783-791. 
130. Li Q, Zemel E, Miller B, Perlman I. Early Retinal Damage in Experimental Diabetes: Electroretinographical and Morphological Observations. Experimental Eye Research 2002;74:615-625.

131. Reichenbach AB, Andreas. Müller Cells in the Healthy and Diseased Retina. 1st Edition ed: Springer; 2010:200.

132. Lieth E, Barber AJ, Xu B, et al. Glial reactivity and impaired glutamate metabolism in short-term experimental diabetic retinopathy. Penn State Retina Research Group. Diabetes 1998;47:815-820.

133. Kusner LL, Sarthy VP, Mohr S. Nuclear Translocation of Glyceraldehyde-3Phosphate Dehydrogenase: A Role in High Glucose-Induced Apoptosis in Retinal Muller Cells. Invest Ophthalmol Vis Sci 2004;45:1553-1561.

134. Verardo MR, Lewis GP, Takeda M, et al. Abnormal Reactivity of Muller Cells after Retinal Detachment in Mice Deficient in GFAP and Vimentin. Invest Ophthalmol Vis Sci 2008;49:3659-3665.

135. Adamiec-Mroczek J, Oficjalska-Mlynczak J, Misiuk-Hojlo M. Roles of endothelin-1 and selected proinflammatory cytokines in the pathogenesis of proliferative diabetic retinopathy: Analysis of vitreous samples. Cytokine 2010;49:269-274.

136. Rui L, Aguirre V, Kim JK, et al. Insulin/IGF-1 and TNF-alpha stimulate phosphorylation of IRS-1 at inhibitory Ser307 via distinct pathways. J Clin Invest 2001;107:181-189.

137. Chan PS, Kanwar M, Kowluru RA. Resistance of retinal inflammatory mediators to suppress after reinstitution of good glycemic control: novel mechanism for metabolic memory. J Diabetes Complications 2010;24:55-63.

138. Liou GI. Diabetic retinopathy: Role of inflammation and potential therapies for anti-inflammation. World Journal of Diabetes 2010;1:12-18.

139. Steinle JJ. Sympathetic neurotransmission modulates expression of inflammatory markers in the rat retina. Experimental Eye Research 2007;84:118-125.

140. Zabolotny JM, Kim YB, Welsh LA, Kershaw EE, Neel BG, Kahn BB. Proteintyrosine phosphatase 1B expression is induced by inflammation in vivo. The Journal of biological chemistry 2008;283:14230-14241.

141. Zheng L, Howell SJ, Hatala DA, Huang K, Kern TS. Salicylate-based antiinflammatory drugs inhibit the early lesion of diabetic retinopathy. Diabetes 2007;56:337-345.

142. Elenkov IJ, Chrousos GP. Stress hormones, proinflammatory and antiinflammatory cytokines, and autoimmunity. Ann N Y Acad Sci 2002;966:290303.

143. Yego EC, Vincent JA, Sarthy V, Busik JV, Mohr S. Differential regulation of high glucose-induced glyceraldehyde-3-phosphate dehydrogenase nuclear accumulation in Muller cells by IL-1beta and IL-6. Investigative Ophthalmology \& Visual Science 2009;50:1920-1928. 
144. Yego EC, Mohr S. siah-1 Protein is necessary for high glucose-induced glyceraldehyde-3-phosphate dehydrogenase nuclear accumulation and cell death in Muller cells. The Journal of Biological Chemistry 2010;285:3181-3190.

145. Manning DR. G proteins: techniques of analysis. 1 ed: CRC Press; 1999:301. 


\section{APPENDIX A. MATERIALS AND METHODS}

\section{Müller Cell Culture}

Rat retinal Müller cells (rMC-1) were cultured and passaged in DMEM medium (HyClone, Logan, UT) containing 5mM glucose (normal glucose) or $25 \mathrm{mM}$ glucose (high glucose) $10 \%$ FBS, and $2 \mathrm{mM}$ L-glutamine. Cells were cultured until they reached $80 \%$ confluency, at this point, FBS concentration was decreased from $10 \%$ to $2 \%$ in $25 \mathrm{mM}$ media starved cells. Cells remained in this starved environment for 18-24 hours to reduce any serum effects from the medium. Immediately after starvation, cells were treated with $10 \mu \mathrm{M}$ salmeterol (beta-2-adrenergic receptor agonist) dissolved into high glucose medium for 6 hours. Additionally, five dishes of cells were used as not treated controls for both treatments in both $25 \mathrm{mM}$ glucose and $5 \mathrm{mM}$ glucose for the duration of the treatment.

Following treatment cells were harvested and pelleted in lysis buffer. In TNF- $\alpha$ inhibitory studies, cells were treated with $5 \mathrm{ng} / \mathrm{ml}$ of TNF- $\alpha$ alone for 30 minutes or 30 minutes pre-treatment with TNF- $\alpha$ followed by $10 \mu \mathrm{M}$ salmeterol for 4 hours. Immediately after treatments, cells were lysed with lysis buffer $(1.58 \mathrm{~g}$ Tris base, $150 \mathrm{ml}$ sterile water, $1.80 \mathrm{~g} \mathrm{NaCl}, 20 \mathrm{ml} 10 \%$ Igepal-40, $5 \mathrm{ml} 10 \%$ Na-deoxycholate, $2 \mathrm{ml} 100 \mathrm{mM}$ EDTA, and $1 \mu \mathrm{g}$ protease inhibitors (all ingredients for lysis buffer, Sigma) and harvested at each of the treatment time points.

\section{shRNA Library Construction}

The sequence for each of the 21-bp shRNA constructs was designed using Invitrogen Block-iT RNA designer ${ }^{\mathrm{TM}}$ (Invitrogen, Carlsbad, CA). The sequence for rat IRS-1 (accession \# NM_012969) was CGAGTTCTGGATGCAAGTGGA and the sequence of the scrambled shRNA was 5-GACGAACCCCTGTTCCGAATG. The mir algorithm was used to design double-stranded cDNAs. For rat IRS-1 the sequence of the forward primer was

5'-TGCTGTCCACTTGCATCCAGAACTCGGTTTTGGCCACTGACTGACCGAGTT CTATGCAAGTGGA and its complementary strand was:

5'-CCTGTCCACTTGCATAGAACTCGGTCAGTCAGTGGCCAAAACCGAGTTCTG GATGCAAGTGGAC. These synthetic oligo constructs were hybridized and cloned into BLOCK-iT ${ }^{\mathrm{TM}}$ Pol II miR RNAi Expression Vector with EmGFP. Each plasmid was grown on agar plates containing $50 \mu \mathrm{g} / \mathrm{ml}$ of spectinomycin. Colonies were selected and sequenced to verify insert sequence, and then a large plasmid preparation was made using Qiagen kits (Qiagen, Baltimore, MD). Upon transient transfection into cells, expression of the shRNA was monitored by GFP fluorescence $(\lambda \mathrm{ex}=488 \mathrm{~nm}, \lambda \mathrm{em}=520 \mathrm{~nm})$.

To determine the effect of transient expression of $5 \mu \mathrm{g}$ of each shRNA/60-mm plate on its target, we probed total RNA by RT-PCR or protein by Western blotting using anti-IRS-1 antibody (SC-559 from Santa Cruz Biotechnology). For the RT-PCR procedure, first-strand cDNA synthesis was performed using the Transcriptor First-Strand 
cDNA Synthesis Kit from (Roche Diagnostics, Indianapolis, IN, USA) using 62 ng of RNA per assay. The RT-PCR primers were designed using a web-based design center (http://www.universalprobelibrary.com). The mRNA level for each protein was quantified using the Universal Probe Library of short hydrolysis locked nucleic acid probes in combination with the primers. The quantification of mRNA was accomplished using the Roche Lightcycler 480 Real-time PCR system and software.

\section{RNA Interference Transfection}

For shRNA studies, cells were passaged and cultured until $80 \%$ confluency, at which time, cells were transfected with plasmid containing shRNA for silencing IRS-1 using lipofectamine for 24 hours. For IRS-1 shRNA + salmeterol studies, following the 24 hours of transfection, cells were treated with $10 \mu \mathrm{M}$ salmeterol for an additional 6 hours. Cells that were designated as IRS-1 shRNA alone were harvested with no further treatment following the 24-hour transfection period. For scrambled shRNA studies, cells were transfected with plasmid containing scrambled shRNA using lipofectamine for 24 hours.

For knockdown studies of TNF- $\alpha$, cells were cultured until $90 \%$ estimated confluency, followed by transfection of cells with shRNA against TNF- $\alpha$ for 18 hours. For TNF- $\alpha$ shRNA + salmeterol samples, cell were first treated with TNF- $\alpha$ shRNA for 18 hours, followed by 6 hours of exposure to $10 \mu \mathrm{M}$ salmeterol.

\section{PKA siRNA Studies}

Cells were cultured in previously mentioned conditions until $90 \%$ confluency, after which cells were transfected with 20nM naked siRNA using Lipofectamine for 8-10hrs. Following a medium change, cells were allowed to proliferate for a period of 24-48 hrs for PKA siRNA alone samples then harvested and pelleted with lysis buffer for experimental analysis. For PKA siRNA + salmeterol samples, following the 24hour proliferation period, cells were treated with $10 \mu \mathrm{M}$ salmeterol for $6 \mathrm{hrs}$, following by cell collection for experimental analyses.

\section{Pertussis Toxin Studies}

Cells were cultured in previously mentioned conditions until $90 \%$ confluency. Cells were transferred into Optimem medium and treated with $50 \mathrm{ng} / \mathrm{ml}$ pertussis toxin (PTX) for $10 \mathrm{hrs}{ }^{145}$. Following the ten-hour treatment period, cells treated with PTX only were harvested and lysed for experimental analysis. PTX + salmeterol samples were treated with $10 \mu \mathrm{M}$ salmeterol for $6 \mathrm{hrs}$ following PTX treatment, followed by cell collection for experimental analyses. 


\section{Beta-Adrenergic Receptor Antagonist Treatment}

In inhibitory studies, cells were treated with 300nM of CGP 20712A ( $\beta$-1-adrenergic receptor antagonist) or 50nM of ICI 118,551 ( $\beta$-2-adrenergic receptor antagonist) ${ }^{97}$ for 30 minutes. Following thirty minutes of antagonist treatment, 5 dishes of cells were designated as controls and harvested with no further treatment, while the remaining cells were treated with $10 \mu \mathrm{M}$ isoproterenol for $1,6,12$, and 24 hours collecting 5 dishes for each timepoint.

\section{Western Blot Analysis}

Protein concentrations in cell lysates were determined by Bradford assay (Thermo Fisher Scientific, Rockford, IL). Once protein concentrations were determined, 100 $\mu \mathrm{g}$ of protein were combined with denaturing sample buffer $(1 \mathrm{~mL} 2 \mathrm{X}$ GDW, $640 \mu \mathrm{L} 1 \mathrm{M}$ Tris-HCL pH 6.8, 420 $\mu \mathrm{L} 30 \%$ glycerol, $250 \mu \mathrm{L} \beta$-mercaptoethanol, $200 \mu \mathrm{L} 0.05 \%$ bromophenol blue, and $0.125 \mathrm{~g}$ recrystallized SDS) to be separated on $4-20 \%$ pre-cast tris-glycine gels (Lonza, Rockland, MD) and transferred to nitrocellulose membranes following separation. Membranes were allowed to block at 4 degrees Celsius in a 5\% BSA solution, overnight with antibody of interest: total and phosphorylated insulin receptor beta Tyr 1150/1151 (diluted 1:250) Cell Signaling, Danvers, MA). All blots were washed and then incubated at room temperature with the anti-rabbit secondary antibodies combined with horseradish peroxidase at 1:5000 dilution for $2 \mathrm{hrs}$. Following incubation with secondary antibodies, blots were washed and placed into ECL reagent (Thermo Fisher Scientific, Rockford, IL). Chemilluminescent detection for immunoreactive bands was viewed using the Kodak ImageStation 4000MM with mean densitometry being calculated for individual bands. Results were expressed as a ratio of phosphorylated to total protein levels in densitometric units with comparisons between not treated vs. drug treatments.

For detection of Akt, analyses were done using the LiCor Odyssey system. Protein analyses were the same as above with the exception that, membranes were allowed to block in a Odyssey blocking solution with total or phosphorylated $\mathrm{Akt}^{\mathrm{Ser} 473}$ (diluted 1:500, Cell Signaling, Danvers, MA). All blots were washed and then incubated at room temperature with the IRDye $800 \mathrm{CW}$ goat anti-Rabbit secondary antibodies (LiCor, Lincoln, NE), at 1:5000 dilution in Odyssey blocking solution with 1\% Tween for $2 \mathrm{hrs}$. Following incubation with secondary antibody, blots were washed and viewed using the Odyssey infrared image system (LiCor, Lincoln, NE) with interval intensities being calculated for individual bands. Results were expressed as a ratio of phosphorylated to total protein levels in densitometric units with comparisons between $5 \mathrm{mM}$ glucose vs. $25 \mathrm{mM}$ glucose, $25 \mathrm{mM}$ glucose vs. TNF- $\alpha$ shRNA treatments, and salmterol vs. TNF- $\alpha$ shRNA treatments.

For PKA studies, results were expressed as a ratio of phosphorylated to total protein levels in densitometric units with comparisons between $5 \mathrm{mM}$ glucose vs. $25 \mathrm{mM}$ glucose, $25 \mathrm{mM}$ glucose vs. PKA siRNA treatments, and salmterol vs. PKA siRNA 
treatments. For PTX studies, results were expressed as a ratio of phosphorylated to total protein levels in densitometric units with comparisons between $5 \mathrm{mM}$ glucose vs. $25 \mathrm{mM}$ glucose, $25 \mathrm{mM}$ glucose vs. PTX treatments, and salmeterol vs. PTX +salmeterol treatments.

\section{ELISA Assays}

Müller cells were cultured under conditions previously stated and were treated either with TNF- $\alpha$ alone, salmeterol alone, TNF- $\alpha+$ salmeterol, or not treated (control). For TNF- $\alpha$ shRNA conditions, cells were treated with TNF- $\alpha$ shRNA, TNF- $\alpha$ shRNA + salmeterol, scrambled shRNA (control), normal glucose, and high glucose. Cell lysates from these treatment groups were transferred to a streptavidin-coated microplate. The amount of DNA fragmentation was analyzed by use of Cell Death Detection ELISA (Roche, Germany), according to manufacturer's instructions. ELISA assays were performed for cleaved caspase 3 (Cell Signaling, Danvers, MA) according to manufacturer's instructions, except that equal protein concentrations were loaded into all wells to allow for analyses based on absorbance values.

Statistical Analysis

All statistical analyses for these investigations were obtained using Prism 4.0b software. Nonparametric tests were conducted for cell culture experiments due to the small sample size for each experiment. For all, the $5 \mathrm{mM}(\#)$ and $25 \mathrm{mM}(*)$ glucose samples (controls) were compared to IRS-1 shRNA treatment groups and salmeterol treatment groups using a Mann Whitney $U$, with $p<0.05$ considered as significantly different. Additionally, a separate comparison was done with IRS-1 shRNA treatment + salmeterol vs. salmeterol treatment alone $(\$)$.

For all PKA studies, the $5 \mathrm{mM}(*)$ and $25 \mathrm{mM}$ (\#) glucose samples (controls) were compared to PKA siRNA treatment groups and salmeterol treatment groups using a Mann Whitney U, with $\mathrm{P}<0.05$ considered as significantly different. Additionally, a separate comparison was done with PKA siRNA treatment + salmeterol vs. salmeterol treatment alone (\$). For all PTX studies, the $5 \mathrm{mM}(*)$ and $25 \mathrm{mM}(\#)$ glucose samples (controls) were compared to PTX treatment groups and salmeterol treatment groups using a Mann Whitney $\mathrm{U}$, with $\mathrm{p}<0.05$ considered as significantly different. Additionally, a separate comparison was done with PTX treatment + salmeterol vs. salmeterol treatment alone (\$). 


\section{APPENDIX B. CHAPTER 2 ABSTRACT}

\section{Purpose}

To determine whether $\beta$-adrenergic receptors require IRS- 1 activity to regulate apoptosis in retinal Müller cells.

\section{Methods}

Müller cells (rMC-1) were cultured in DMEM medium grown in normal (5mm) or high glucose $(25 \mathrm{mM})$ conditions. Medium was supplemented with $10 \%$ FBS and antibiotics. Cells were allowed to reach $80-90 \%$ confluency. After becoming appropriately confluent, cells were placed in medium with reduced serum (2\%) for 18-24 hours to eliminate any effects of FBS. Cells were then transfected with $10 \mu \mathrm{g}$ of IRS-1 shRNA. Forty-eight hours following transfection, cells were lysed and harvested for protein analysis using Western blotting. In additional experiments, some cells were treated with $10 \mu \mathrm{M}$ salmeterol 24 hours following transfection with IRS-1 shRNA. To determine whether IRS-1 directly regulates apoptotic events in the insulin-signaling pathway in retinal Müller cells, a Cell Death assay kit (Roche) was used. In TNF $\alpha$ inhibitory studies, cells were treated with $5 \mathrm{ng} / \mathrm{ml}$ of TNF $\alpha$ alone for 30 minutes or 30 minutes pre-treatment with TNF $\alpha$ followed by salmeterol for 4 hours.

\section{Results}

Müller cells treated with $5 \mathrm{ng} / \mathrm{ml} \mathrm{TNF} \alpha$ in $25 \mathrm{mM}$ glucose significantly increased phosphorylation of IRS-1 ${ }^{\text {Ser307 }}$. Treatment with the selective beta-2-adrenergic receptor agonist, salmeterol, significantly decreased phosphorylation of IRS- $1^{\text {Ser307 }}$. Following IRS-1 shRNA transfection+salmeterol treatment, Bax and cytochrome c levels were significantly decreased. Salmeterol+IRS-1 shRNA also decreased cell death and increased protein levels of $\mathrm{Bcl}-\mathrm{xL}$, an anti-apoptotic factor.

\section{Conclusions}

In these studies, we identify for the first time that salmeterol, a beta-2-adrenergic receptor agonist, can reduce retinal Müller cell death through IRS-1 actions These findings also suggest the importance of IRS-1 in beta-adrenergic receptor signaling in the prevention of cell death in retinal Müller cells. 


\section{APPENDIX C. CHAPTER 3 ABSTRACT}

\section{Purpose}

The goal of this study was to determine the relationship of TNF- $\alpha$ and the downregulation of insulin receptor signaling in retinal Müller cells cultured under hyperglycemic conditions and the role of $\beta$-adrenergic receptors in regulating these responses.

\section{Methods}

Retinal Müller cells were cultured in normal glucose $(5 \mathrm{mM})$ or high glucose $(25 \mathrm{mM})$ conditions until the cells reached $80 \%$ confluency and then were reduced to $2 \%$ serum for 18-24 hours. Following serum reduction, cells were treated with 10uM salmeterol followed by Western blot and ELISA analyses. For TNF- $\alpha$ inhibitory studies, cells were treated with $5 \mathrm{ng} / \mathrm{ml}$ of TNF- $\alpha$ alone for 30 minutes or 30 minutes pretreatment with TNF- $\alpha$ followed by salmeterol for 6 hours. In silencing studies of TNF- $\alpha$, cells were cultured until $90 \%$ estimated confluency, followed by transfection of cells with shRNA against TNF- $\alpha$ for 18 hours.

\section{Results}

TNF- $\alpha$ only treatments in Müller cells resulted in a significant decrease of tyrosine phosphorylation of the insulin receptor, as well as a decrease in phosphorylation of Akt in high glucose conditions. Treatment of cells with $10 \mu \mathrm{M}$ salmeterol, a $\beta$-2-adrenergic receptor agonist, significantly increased the phosphorylation of both insulin receptor and Akt. TNF- $\alpha$ shRNA significantly decreased phosphorylation of IRS-1 ${ }^{\text {Ser307 }}$, which was further decreased following salmeterol+TNF- $\alpha$ shRNA. Knockdown of TNF- $\alpha$ or treatment with salmeterol significantly reduced cell death in retinal Müller cells.

\section{Conclusions}

These studies demonstrate that treatment with a $\beta$-adrenergic receptor agonist in vitro can restore the loss of insulin receptor activity noted in diabetes. By decreasing the levels of TNF- $\alpha$, decreasing phosphorylation of IRS-1 ${ }^{\text {Ser307 }}$, while increasing tyrosine phosphorylation of insulin receptor, these results suggest a possible mechanism by which restoration of $\beta$-adrenergic receptor signaling may protect the retina against diabetes-induced damage. 


\section{APPENDIX D. CHAPTER 4 ABSTRACT}

\section{Purpose}

To determine whether $\beta 2$-adrenergic receptors on retinal Müller cells are regulated by $\mathrm{G}_{\mathrm{s}}$ or $\mathrm{G}_{\mathrm{i}}$.

\section{Methods}

Müller cells (rMC-1) were cultured in DMEM medium grown in high glucose $(25 \mathrm{mM})$ conditions. Medium was supplemented with 10\% FBS and antibiotics. Cells were continuously fed and allowed to grow until reaching $80-90 \%$ confluency. Cells were then serum-starved for 18-24 hours to eliminate any effects of insulin from the FBS. Cells were transfected with 20nM PKA siRNA transfection for a period 10-12hrs followed by cell lysis and Western blotting and ELISA analysis. For pertussis toxin experiments, cells were treated with 50ng/ml pertussis toxin (PTX) for $10 \mathrm{hrs}$. For both PKA siRNA and PTX studies, cells were treated with $10 \mu \mathrm{M}$ salmeterol following treatments of PTX and PKA siRNA. Following salmeterol treatment, cells were lysed and harvested for various proteins of interest.

\section{Results}

PKA siRNA only and PKA siRNA + salmeterol samples produced a significant decrease in Akt phosphorylation in retinal Müller cells. This was accompanied by a significant increase in phosphorylation on IRS-1 ${ }^{\text {Ser307 }}$ in PKA siRNA samples, suggesting that IRS-1 ${ }^{\text {Ser307 }}$ phosphorylation signaling to Akt in retinal Müller cells is mediated by $\mathrm{G}_{\mathrm{s}}$ via PKA. Combination treatments of PKA siRNA + salmeterol yielded a significant decrease in cell death vs. $25 \mathrm{mM}$ glucose samples. However, activation of Gi by pertussis toxin and pertussis toxin+salmeterol resulted in significant decreases in cell death. Additional studies revealed that Müller cells treated with PTX and PTX + salmeterol significantly increased phosphorylation of Akt and significantly decreased in IRS-1 ${ }^{\text {Ser307 }}$ phosphorylation.

\section{Conclusions}

Our findings suggest that PKA is needed for $\beta 2$-adrenergic receptor restoration of insulin receptor signaling in hyperglycemia. Activation of $G_{i}$ and reduced coupling to $G_{s}$ on B2-adrenergic receptors resulted in activation of Akt and other cell survival mechanisms in retinal Müller cells. For the first time to our knowledge, we show that ß2-adrenergic receptors in retinal Müller cells undergo a PKA-mediated dual coupling from $\mathrm{G}_{\mathrm{s}}$ to $\mathrm{G}_{\mathrm{i}}$ protein to provide anti-apoptotic signaling in a high glucose environment. These results strongly suggest that beta-adrenergic receptors mediate changes in apoptosis and insulin signaling in the retina. 


\section{VITA}

Robert Jason Walker was born in Meridian, Mississippi in 1982 to Robert and Martha Walker. Jason graduated from Meridian High School in May of 2001, and then enrolled at Alcorn State University for undergraduate studies. Jason graduated from Magna cum Laude from Alcorn State University with a Bachelor of Science degree in Chemistry. Jason then went on to pursue a Master's of Science degree in cellular, molecular, and systemic Physiology from Southern Illinois University in Carbondale, Illinois. Prior to completing his Master's work, Jason gained acceptance into the Integrated Program in Biomedical Sciences (IPBS) at the University of Tennssee Health Sciences Center (UTHSC) in Memphis to work on his Ph.D. in the area of Neuroscience. While working on his doctorate degree, Jason has received an F31 training grant from the National Institute of Health, as well as a travel grant to the ARVO meeting in Ft.

Lauderdale, FL. In August 2010, Jason was selected as 1 of 20 students to participate in the Marine Biological Laboratory’s Fundamental in Vision Research Course in Woodshole, MA. 